\title{
ANÁLISE SIMULADA NA RECUPERAÇÃO DE SOLOS AFETADOS POR SAIS E NA RESPOSTA PRODUTIVA DOS CULTIVOS
}

\section{LAZARO NONATO VASCONCELLOS DE ANDRADE Engenheiro Agrônomo}

Orientador: Prof. Dr. DÉCIO EUGÊNIO CRUCIANI

Tese apresentada à Escola Superior de Agricultura Luiz de Queiroz, Universidade de São Paulo, para a obtenção do título de Doutor em Agronomia, Área de Concentração: Irrigação e Drenagem

P I R A C I C A B A

Estado de São Paulo - Brasil

JULHO DE 1998 


\section{ERRATA}

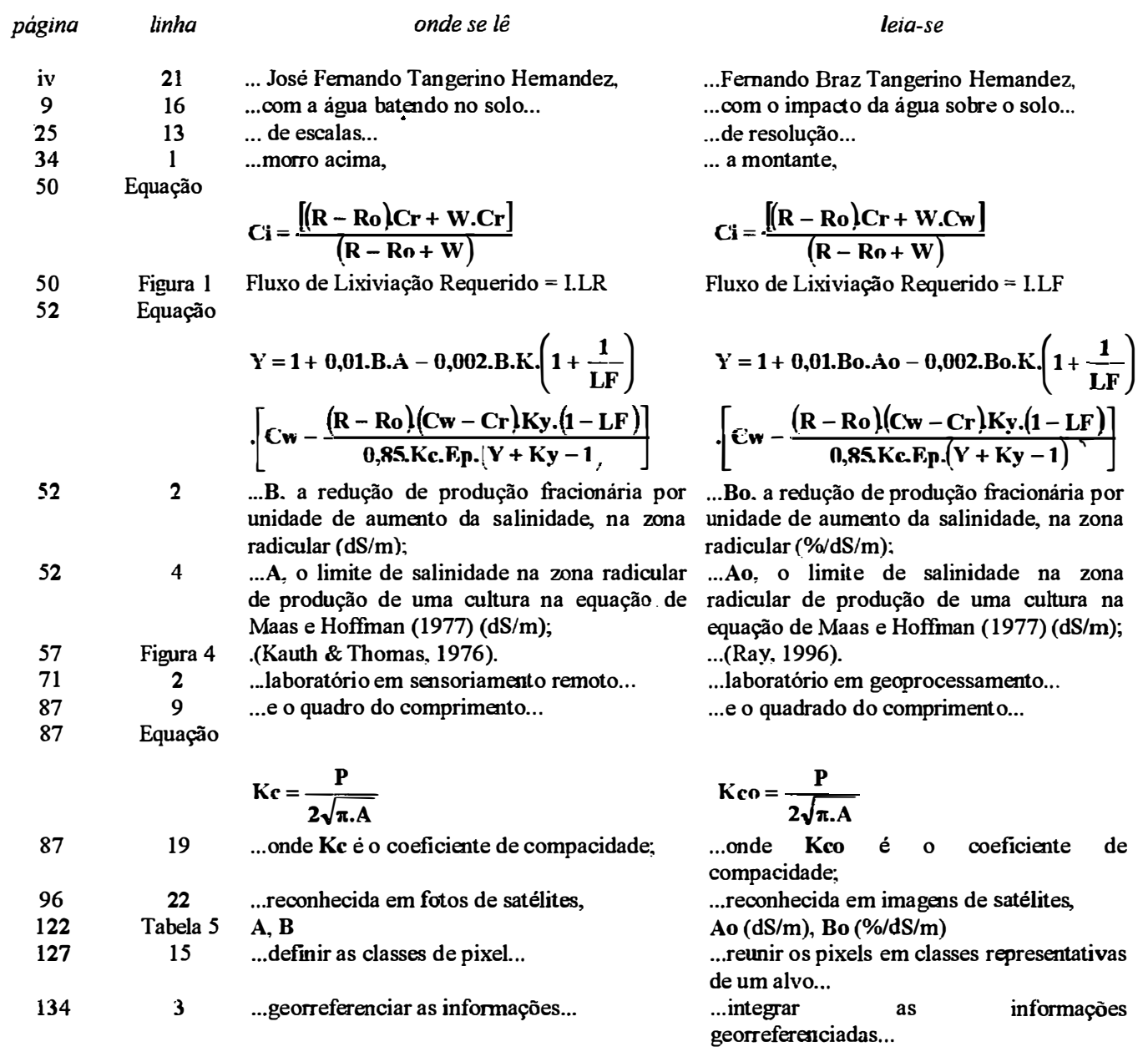

Incluir no ítem REFERÊNCIAS BIBLIOGRÁFICAS, página 149:

RAY, T. W. Remote monitoring of land degradation in arid/semiarid regions. Passadena, 1995. 391p. Thesis (Ph.D) - California Institute of Technology. 
Dados Internacionais de Catalogaçāo na Publicação (CIP) DIVISÃo DE BIBLIOTECA E DOCUMENTAÇÃO - Campus "Luiz de Queiroz"/USP

Andrade, Lazaro Nonato Vasconcellos de

Análise simulada na recuperaçāo de solos afetados por sais e na resposta produtiva dos cultivos / Lazaro Nonato Vasconcellos de Andrade. - - Piracicaba, 1998.

159 p. : il.

Tese (doutorado) - - Escola Superior de Agricultura Luiz de Queiroz, 1998.

Bibliografia.

1. Água de irrigaçāo 2. Geoprocessamento 3. Recuperaçāo do solo 4. Salinidade 5. Sensoriamento remoto 6. SiG (Sistema de computador) 7. Simulaçāo I. Título 


\section{ANÁLISE SIMULADA NA RECUPERAÇÃO DE SOLOS AFETADOS POR SAIS E NA RESPOSTA PRODUTIVA DOS CULTIVOS}

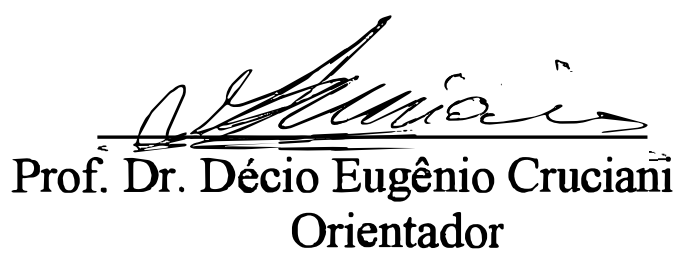




\section{O CALDEIRÃO}

O destino do fogo depende da madeira; enquanto houver madeira abaixo, o fogo arderá acima.

O mesmo ocorre na vida humana.

Há um destino que dá força à sua vida

e que se consolida quando o homem consegue posicionar corretamente a vida e o destino, harmonizando-os.

Assim, toda pessoa de boa vontade pode, de alguma forma, ter êxito.

Por mais humilde que seja a sua posição, desde que esteja disposta a purificar-se, ela será aceita.

Alcançará então uma posição em que seu trabalho se mostrará fecundo e ela encontrará, por isso, reconhecimento.

Em épocas de grande desenvolvimento cultural é de máxima importância que se realize uma obra significativa. Se um homem se dedica inteiramente a uma obra dessa natureza, ainda que venha a ser objeto de inveja e má vontade, não correrá perigo. Quanto mais ele se limitar às suas tarefas positivas, tanto menos lhe poderão afetar os invejosos 


\section{AGRADECIMENTOS}

À Universidade do Estado da Bahia, pelo seu programa de capacitação docente, através da Pró-Reitoria de Pesquisa e Ensino de PósGraduação, que possibilitou a conclusão deste trabalho.

À Escola Superior de Agricultura "Luiz de Queiroz", da Universidade de São Paulo, pelos ensinamentos acadêmicos e de vida proporcionados pelos seus professores, funcionários e alunos de graduação e pós-graduação.

À Coordenadoria de Aperfeiçoamento de Pessoal de Ensino Superior, pela bolsa concedida para o desenvolvimento, a execução e a conclusão deste trabalho.

Aos professores Décio Eugenio Cruciani, José Antônio Frizzone, Tarlei Arriel Bottrel, Marcos Vinícius Folegatti, Hugo Ghelfi Filho, Antônio F. L. Ollita, José Carlos Quittolina, Carlos Alberto Vettorazzi, Rubens Angulo Filho, Gerd Sparovec, José Carlos Kiell, Sergio Botelho, Durval Dourado Neto, Paulo Leonel Libardi, Quirino Augusto C. Carmello, da Universidade de São Paulo, pela paciência, pela dedicação e pela vontade para as horas difíceis, para as dúvidas e para as soluções dos problemas.

Ao Prof. Gilberto Câmara e à equipe do SPRING, pela oportunidade de participar de tão valoroso projeto.

Aos colegas e amigos José Fernando Tangerino Hernandes, José Elenildo Queiroz, Vital Pedro S. Paz, Carlos Brancildes M. Calheiros, José Orlando Piauilino, Maristélio da Cruz Costa, Bebeto, Polaco, Alexandre, Renato Francescato, Celso Freitas, Joaquim, Roberto D. 
Medeiros e todos os outros, agradeço pela consideração e pela estima proporcionada na convivência durante o curso de pós-graduação.

À Roberta Helena F. R. Bacha pela presteza em atender-me as solicitações, pelo sorriso que sempre esteve presente no atendimento a todos os colegas e pelo carinho dado à minha família.

Às professoras Nádia Hage Fialho, Regina Celi, Ângela e Nélia da Pró-Reitoria de Ensino e Pós Graduação da Universidade do Estado da Bahia, pela contribuição à concretização de vários trabalhos de minha autoria.

Ao Prof. Jaques Fadigas e a todos os colegas e amigos da Gerência de Informática da Universidade do Estado da Bahia que viram a necessidade e contribuíram com os materiais necessários nas horas críticas.

Aos meus pais Antônio Lazaro Souza de Andrade e Delza Vasconcellos de Andrade que sempre lutaram pela minha educação e foram indispensáveis neste momento também.

A Nilza Andrade de Carvalho Araujo, Maria Emília, Bartolomeu e Gabriel pelas horas de lazer que passamos juntos.

A Edson Luiz e sua família pelas tentativas de mostrar o melhor caminho.

A todos os amigos e parentes que contribuíram, de alguma forma, para a realização deste trabalho, meus sinceros agradecimentos.

E um especial agradecimento a minha esposa Heloísa e a minha filha Gabriela por me aturarem nos momentos dificeis deste trabalho.

A Natália Andrade e Maria da Anunciação Andrade que morreram sem poder ver a realização deste momento. 


\section{SUMÁRIO}

SUMÁRIO vi

RESUMO

SUMMARY

1. INTRODUÇÃO 1

2. REVISÃO DE LITERATURA 3

2.1. Degradação e desertificação 3

2.1.1. O problema da degradação das terras 3

2.1.1.1. Definindo a degradação das terras 3

2.1.1.2. A extensão do problema 5

2.1.1.3. O processo de degradação das terras 7

2.1.1.3.1. Compactação do solo 8

2.1.1.3.2. Erosão hídrica 9

2.1.1.3.3. Erosão eólica 10

2.1.2. A função vital da vegetação 12

2.1.3. Monitorando a desertificação 12

2.2. Degradação e desertificação na Bahia 14

2.2.1. Tendências e perspectivas 20

2.2.2. Cenário desejável $\quad 22$

2.3.Aplicação de modelos de simulação superficiais e subsuperficiais da terra, baseados em Sistemas de Informação Geográfica (SIG) 23

2.3.1. Aplicações em modelagem de dados espaciais 25

2.3.1.1. O modelo de simulação USLE 26

2.3.1.2. O modelo de simulação ANSWERS 29 
2.3.1.3. O modelo de simulação AGNPS

2.3.1.4. O modelo de simulação CMLS 35

2.3.1.5. O modelo de simulação LEACHM 38

2.3.1.6. O modelo de simulação TOPMODEL 41

2.4. Modelo de previsão da resposta produtiva dos cultivos à salinidade da água e do solo.

2.5. Sensoriamento remoto no estudo da vegetação e dos solos salinos

2.5.1. Índices de vegetação

2.5.2. Aplicações de sensoriamento remoto no estudo da salinidade dos solos

2.5.2.1.Sensoriamento remoto para estudo da degradação das terras

2.5.2.2. O ambiente de desenvolvimento Linux como base operacional do sistema de informações geográficas Spring

3. MATERIAIS E MÉTODOS

3.1. Definindo o esquema conceitual

3.1.1. Inserção de dados de caracterização fisiográfica da bacia do rio Salitre em planos de informação

3.1.1.1. O plano de informação geologia

3.1.1.2. O plano de informação solos

3.1.1.3. O plano de informação vegetação

3.1.1.4.O plano de informação densidade de drenagem 
3.1.2.Inserção de dados de caracterização climática da bacia do rio Salitre

3.1.3.Plano de informação sobre salinidade das águas superficiais e subterrâneas

3.1.4.Plano de informação sobre 0 zoneamento agroecológico

3.1.5. Esquema conceitual

3.2. Utilizando a LEGAL para o modelo de Prendergast 115

4. RESULTADOS E DISCUSSÃO

4.1. Exemplo de resposta produtiva para a cultura do tomate

4.2. Utilização de técnicas de sensoriamento remoto para quiantificação da degradação das terras

5. CONCLUSÕES E RECOMENDAÇÕES 


\section{ANÁLISE SIMULADA NA RECUPERAÇÃO DE SOLOS AFETADOS POR SAIS E NA RESPOSTA PRODUTIVA DOS CULTIVOS}

\section{Autor: LAZARO NONATO VASCONCELLOS DE ANDRADE Orientador: PROF. DR. DÉCIO EUGENIO CRUCIANI}

RESUMO

Uma inter-relação entre a produção de uma cultura e a salinidade da água de irrigação é desenvolvida, utilizando-se um modelo de simulação em LEGAL (Linguagem Espacial para Geoprocessamento Algébrico), para a bacia do rio Salitre, no estado da Bahia, Brasil. A relação pode ser usada como uma função de produção para quantificar as ramificações econômicas de práticas que aumentam a salinidade da água de irrigação, tais como a disposição de água drenada da superficie dentro do sistema de suprimento de água de irrigação.

Linhas de ordenação para níveis aceitáveis de salinidade da água de irrigação, em uma região, podem ser estabelecidas. O modelo pode também ser usado para determinar a suscetibilidade de uma cultura para uma 
região irrigada, se a salinidade da água de irrigação é alta. Em locais onde trabalhos experimentais são requeridos para determinar a resposta de produção da cultura à salinidade da água de irrigação o modelo pode ser usado como uma primeira estimativa de função de resposta. 


\title{
SIMULATION ANALYSIS IN THE RECUPERATION OF SALT
}

\author{
AFECTED SOILS AND CROP YIELD RESPONSE
}

\author{
Author: LAZARO NONATO VASCONCELLOS DE ANDRADE \\ Adviser: PROF. DR. DÉCIO EUGENIO CRUCIANI
}

SUMMARY

A relationship between crop yield and irrigation water salinity is developed using a simulation model in LEGAL (Linguagem Espacial para Geoprocessamento Algébrico) for the basin of the Salitre river in the state of Bahia, Brazil. The relationship can be used as a production function to quantify the economic ramifications of management which increase irrigation water salinity, such as disposal of surface and sub-surface saline drainage water into the irrigation water supply system.

Guidelines for the acceptable level of irrigation water salinity in a region can then be established. The model can also be used to determine crop suitability for an irrigation region, if irrigation water salinity is high. Where experimental work is required to determine crop 
yield response to irrigation water salinity, the model can be used as a first estimate of the response function. 


\section{INTRODUÇÃO}

Esta investigação tem a finalidade de demonstrar como um Sistema de Informação Geográfica (SIG) pode ser usado para compreender e monitorar a degradação das terras de agricultura marginal, utilizadas em agricultura irrigada e com progressivo abandono dos campos cultivados.

Neste trabalho, procurar-se-á um método de análise que permita determinar a resposta de produção de uma determinada cultura à salinidade da água de irrigação e à salinidade do solo, com o uso de modelos preditivos, utilizando-se as técnicas de geoprocessamento e a linguagem espacial de geoprocessamento algébrico (LEGAL), para o cruzamento entre diferentes planos de informação.

Linhas de ordenação para níveis aceitáveis de salinidade da água de irrigação, em uma determinada região, podem ser estabelecidas e a susceptibilidade da cultura, para aquela condição regionalizada, poderá ser verificada pela salinidade da água de irrigação, em conjunto com o processo de lixiviação de sais do solo, como fatores limitantes.

Dessa forma, o método deverá estabelecer parâmetros quantitativos e qualitativos, considerando-se aspectos agrícolas e econômicos de produção; a intenção é racionalizar a atividade produtiva de uma determinada cultura, permitindo o controle das variáveis envolvidas no processo produtivo, a recuperação do solo degradado, além do 
estabelecimento da atividade agrícola a níveis aceitáveis de rentabilidade por área cultivada.

Utilizando-se técnicas de geoprocesamento, uma análise por simulação deverá ser realizada, para estabelecer fronteiras e monitorar os solos afetados por sais na bacia do rio Salitre, estado da Bahia.

Além disso, a relação entre vegetação e desertificação é analisada, e a necessidade de monitoramento da vegetação, esclarecida, de forma a que, o monitoramento de regiões áridas apresente uma tendência diferente, em relação às práticas mais desenvolvidas de sensoriamento remoto em áreas úmidas vegetadas. As plantas de regiões áridas são unicamente adaptadas a sobreviver em seu ambiente, e tais adaptações tendem a reduzir a habilidade do sensoriamento remoto convencional a medir a cobertura de plantas.

Far-se-á uma apresentação do panorama geral das pesquisas em modelagem experimental de dados de campo em conjunto com os de sensoriamento remoto, no monitoramento de solos afetados por sais.e dos fatores relacionados ao processo de degradação.

Por fim, este trabalho procurará responder às seguintes questões: é possível monitorar a degradação de áreas de agricultura marginal, onde se aplica irrigação e onde ocorre um progressivo abandono de terras? Conhecendo a interação entre o processo degradativo e a resposta dos cultivos, é possível regionalizar essas respostas, pela aplicação de um modelo que utilize tanto o Software para Processamento de Informações Georreferenciadas - SPRING-, quanto a Linguagem Espacial de Geoprocessamento Algébrico - LEGAL? Finalmente, o SPRING e a LEGAL constituem ferramentas adequadas para essa finalidade? 


\section{REVISÃO DE LITERATURA}

\section{1. - Degradação e desertificação.}

Nesta introdução, define-se a degradação das terras e discutese a extensão desse problema. Será examinado o processo pelo qual as terras áridas se degradam; será mostrado que a cobertura esparsa da vegetação em regiões áridas é um importante fator para o controle da degradação e, por outro lado, que ajuda a indicar onde o processo de degradação está ocorrendo.

2.1.1. O problema da degradação das terras.

2.1.1.1. Definindo a degradação das terras.

Próximo ao ano de 1949, foram relatados os primeiros aspectos relativos à degradação de terras para o cultivo, em extensas áreas das regiões semi-áridas e subúmidas do Norte da África, na fronteira com o deserto do Saara. O termo cunhado para esse processo de degradação foi "desertificação". O problema já havia sido observado, no mundo Mediterrâneo, há aproximadamente dois milênios, pelo senador romano 
Cícero, que falou da destruição das florestas do norte da África e da barreira à sua recuperação, proveniente das áreas desertas. A devastadora seca de Sahel, no período de 1968 a 1973 e o aparente avanço acelerado, para o sudoeste, do Deserto do Saara frutificaram numa extensiva discussão internacional do problema e na formação da Conferência das Nações Unidas em Desertificação - UNCOD (United Nations Enviroment Programe [UNEP], 1992).

Numa reunião, durante 1977, em Nairobi, Kenya, a UNCOD definiu a desertificação como segue: "Desertificação é a diminuição ou a destruição do potencial biológico da terra e pode conduzir definitivamente para condições desérticas. Essa questão da degradação, em grande extensão, do ecossistema implica a redução e a destruição do potencial biológico, isto é, da produção de plantas e de animais para múltiplos usos e propósitos, numa época em que o aumento da produtividade é necessário para fornecer suporte ao crescimento das populações" (UNEP, 1978).

Durante os anos que se seguiram, várias agências, instituições científicas e cientistas individualmente acharam a definição acima inadequada (UNEP, 1992). Em resposta, vários grupos desenvolveram outras definições, provocando uma enorme confusão. Além disso, oscilações climáticas cíclicas e relações entre essas flutuações e a produtividade da vegetação têm sido observadas nas imagens de satélite; tais relações todavia, não necessariamente diferenciam os conceitos de desertificação e de oscilações climáticas (UNEP, 1992).

Em 1992, a UNCOD produziu a seguinte definição de desertificação: "Desertificação é a degradação da terra em regiões áridas, 
semi-áridas, e subúmidas, resultante unicamente do impacto adverso humano."

Não por acaso, o mais significativo aspecto dessa definição está focado no "impacto humano". A diferenciação entre a desertificação e as flutuações climáticas, tais como a seca, repousa na notória exacerbação de danos produzidos pelas atividades humanas. A definição de desertificação, oferecida por Mainguet (1994), estabelece que a desertificação é "revelada pela seca", mas "causada pelas atividades humanas". Aproximadamente um quarto da área de terra vegetada do planeta tem sofrido elevado distúrbio e um adicional de $28 \%$ tem sofrido distúrbio moderado (World Resource Institute [WRI], 1993). Este nível de distúrbio sugere que grandes áreas de superficie da terra têm um potencial significativo de sofrer degradação através da atividade humana.

2.1.1.2. A extensão do problema.

O World Resource Institute (1992) relata que "passados 45 anos, aproximadamente $11 \%$ do solo vegetado da Terra ficaram degradados e tiveram a sua função biótica original reduzida, a ponto de, não sendo mais efetiva, sua recuperação poder ser custosa e, em alguns casos, impossível". A UNCOD estabeleceu que, para 1992 a desertificação afetaria $70 \%$ das áreas secas do mundo (3,6 bilhões de hectares) ou, aproximadamente, um quarto da área total de terra do planeta (UNEP, 1992). Entretanto, a UNCOD tem questionado essas estimativas, por trabalhos tais como os de Warren \& Agnew (1988), que apontaram para o fato de as áreas áridas, usadas para a 
estimativa, serem também áridas para qualquer forma de agricultura. Nesse ínterim, a definição da UNEP (1992) de "áreas marginais" inclui "as áreas de reserva, as terras secas largamente desocupadas, que não são usadas, ou são usadas só ocasionalmente, por pastoreio nômade", de forma a sugerir que a área estimada de terra marginal degradada pode ser aumentada. Mas, uma vez que a estimativa total de área pode aumentar, o procedimento pode produzir pequenas variações na fração de terra usável árida que tem sido degradada.

Uma vez que a área de terras áridas utilizáveis é somente uma parte do valor cotado pela $\mathrm{UNCOD}$, a região de risco representa um sexto da superfície da Terra, e a área reduzida de terras áridas, até o momento inclusas, são aquelas mais utilizadas pelas atividades humanas.

O segundo importante aspecto da extensão da degradação é a questão do potencial para revertê-la. Nelson (1988) expressou a visão de que "a extensão da desertificação, como um estado irreversível, tem provavelmente sido exagerada, embora seja correto classificá-la como um sério problema". O horizonte superficial perdido pode, usualmente, ser reconstruído a um dado tempo, e é bem conhecido o processo da sucessão biológica, mostrando que um ecossistema florestal pode recuperar um campo abandonado em poucos séculos. $O$ trabalho humano pode acelerar a regeneração da camada superficial ou dos ecossistemas, reduzindo o tempo necessário para a regeneração, mas isso requer consideráveis esforços econômicos. Em casos extremos de degradação, onde a fração argila do solo é completamente perdida, ou, invadindo a flora, fica ela extremamente danificada, o recobrimento natural do ecossistema original não irá ocorrer. 
Dregne (1983) relatou que aproximadamente 1,3 milhões de quilômetros quadrados de terras secas da América do Norte têm sido "severamente" ou "muito severamente" degradados.

Nos últimos 100 anos, os desertos de Sonora e Chihuahuan têm ficado perceptivelmente mais áridos, embora essas áreas tenham sido desertos durante um tempo muito longo (Sheridan, 1981). O problema está, longe de ser vencido:

"A introdução do sistema de irrigação por aspersão, especialmente o sistema tipo pivô central, tem proporcionado previamente a insustentabilidade de terras arenosas para serem cultivadas com sucesso. E quando aqueles solos são abandonados por razões econômicas ou de armazenamento de água, os Estados Unidos ficarão sujeitos a um grande evento de erosão eólica, que já ocorreu no passado" (Dregne, 1983).

2.1.1.3. O processo de degradação das terras

Outro item significante na definição corrente, referida acima, da UNCOD sobre a desertificação é a idéia de "degradação das terras". A UNCOD definiu a degradação das terras como segue:

"Degradação é a redução de recursos potenciais por um ou uma combinação de processos agindo sobre a terra. Estes processos incluem erosão hídrica, erosão eólica $e$ 
sedimentação por aqueles agentes, provocando redução no total ou na diversidade da vegetação natural. "(UNEP,1992). Sheridan (1981) caracterizou a aflição da degradação das terras como através dos seguintes sintomas: redução gradativa do nível do lençol freático, salinização da superficie do solo e da água, redução das águas superficiais, elevada erosão não natural do solo, e a desolação da vegetação nativa. Dregne (1983) indica como os maiores processos de desertificação de regiões áridas a erosão da água, a erosão eólica, a salinização, a saturação, e a compactação do solo. Adicionalmente, o mecanismo de formação de pavimentos desérticos e de camadas de solos cimentadas por carbonato de cálcio, encontradas nos desertos e em outras regiões áridas e semi-áridas, faz o solo mais vulnerável à erosão. Através desses diferentes processos, a terra toma-se mais estéril e fica efetivamente mais próxima ao deserto, com ou sem variações climáticas. Serão mostrados brevemente alguns desses processos.

\subsection{Compactação do solo.}

A compactação do solo é resultado da pressão exercida nele pelo impacto da chuva, pelo pastoreio animal, pelas grandes variações repetitivas no estado da água do solo, e finalmente por tratores e outras maquinarias agrícolas (United States Departament of Agriculture [USDA], 1993).

A compactação causada somente pelas variações repetitivas do estado da água no solo é chamada de "compactação da água", enquanto a causada pela pressão de máquinas e animais, como também pelo impacto da 
chuva, é chamada de "compactação mecânica" (USDA, 1993). Camadas compactadas de solos restringem a infiltração de água e aceleram a erosão superficial do solo nos períodos de chuva (Hillel, 1982; Dregne, 1983). Se a camada compactada é muito próxima à superfície do solo, a água pode não penetrar até o nível de crescimento radicular das plantas, ou mesmo até horizontes mais profundos (Hillel, 1982; Dregne, 1983). A redução da penetração de água no solo irá fazer o solo efetivamente mais árido que aquele esperado, devido à variação climática (Dregne, 1983). Camadas superficiais compactadas podem impedir o crescimento de plântulas, pela penetração na superficie do solo, enquanto que camadas mais profundas compactadas podem restringir o crescimento de raízes, dentro das camadas profundas do solo (Hillel, 1982; Dregne, 1983).

\subsection{Erosão hídrica.}

Relatos do World Resource Institute $(1992,1993)$ indicam que a erosão da água é o mais sério problema da degradação da terra em uma escala global. A erosão da água começa com a água batendo no solo.

O USDA (1993) reconhece quatro tipos de erosão: por runoff laminar, em sulcos, em voçoroca, e em túnel (ou canalização, ou afunilamento). A erosão laminar é uma remoção, aproximadamente não uniforme, de solo para uma área fora do local de desenvolvimento, de fácil identificação pelos canais de água formados. Em sequeência de desenvolvimento tem-se a erosão em sulcos e as voçorocas. A erosão laminar pode ser séria em inclinações de somente 1 a 2 por cento, mas é geralmente 
grave a fortes inclinações, em gradientes de solo. Erosão em sulcos é a remoção de solos causada por vários cortes de pequenas dimensões, canais conspícuos, onde a runoff é concentrada. Os pequenos canais podem ser facilmente corrigidos pelo cultivo. Mais sérias são as erosões em voçorocas: a água corta profundamente o solo, ao longo da linha de fluxo. Os canais resultantes desse tipo de erosão não podem ser ordinariamente corrigidos para o cultivo, e pode ficar impossível a utilização de maquinaria. (Dregne, 1983; USDA, 1993; Mainguet, 1994).

O último processo, menos usual, é o tipo de erosão proporcionada pela água em forma de funil. Ele ocorre quando subsuperfícies ou camadas subsuperficiais são mais susceptíveis ao movimento livre da água que as camadas superficiais. A água ganha entrada no interior da subsuperfície, através de fendas ou buracos. A água penetra no material subsuperficial e move-se para baixo, no interior do solo, ou, se existir um caminho preferencial, completamente para fora do solo. Isso forma uma séries de túneis largos e coalescentes, e, na direção desses túneis, pode produzir um aumento da largura, em forma de funil (USDA, 1993). Tal tipo de erosão é um processo danoso, uma vez que, sobre esses minadouros embaixo da superfície, pode ocorrer o colapso, pelo peso de uma pessoa trabalhando, de um animal, ou de uma maquinaria.

\subsection{Erosão eólica.}

Em escala global, a erosão eólica não é um problema tão sério quanto a erosão hídrica (Holy, 1980; WRI, 1992; WRI, 1993), mas é um 
processo que afeta muitas regiões áridas e semi-áridas. Assim como a erosão hídrica, a eólica envolve a remoção de partículas pelo movimento de um fluido. Neste caso, o fluido é o ar. Como na erosão hídrica, as partículas finas são tipicamente perdidas em primeiro lugar; nesse ínterim, o avanço das perdas de matéria orgânica e de nutrientes, dá-se geralmente de forma conjunta, já que se atraem e formam estruturas complexas. (Dregne, 1983). O potencial final, resultado da erosão eólica continuada, é uma área de ativas barreiras de dunas (Dregne, 1983). O estudo clássico dessa relação entre o vento e a areia foi realizado por Bagnold (1942), que focou na areia a abertura dos desertos, em áreas onde a vegetação é geralmente esparsa. Ele apontou para o fato de que a vastidão do movimento da areia ocorre no sentido de elevar o nível do solo.

Se a superfície é coberta por objetos que não podem ser removidos pelo vento, tais como pedras ou vegetação, a rugosidade produzida por eles vai restringir a habilidade do vento para mobilizar e transportar a areia. Os grãos de areia, saltando, vão se depositar dentro dos espaços, entre as pedras ou no interior da vegetação.

As formações rochosas cuja gênese tem a abrasão continuada da areia em suspensão, em áreas desérticas, atesta o poder das areias como agente erosivo, em conjunção com o vento. A vegetação é também afetada pela ação abrasiva dos grãos de areia. Fryrear et al. (1973), em experimentos laboratoriais com gramíneas, sobre condições de areia em suspensão (vento de areia), encontraram ruptura de células, secagem e exposição de tecidos, além de aumento da ação de insetos e de doenças. 
2.1.2. A função vital da vegetação.

Quando muitas pessoas imaginam o deserto, concebem uma vasta área somente com areias; esse quadro porém, somente é verdadeiro para regiões extremamente áridas, tais como o Deserto do Saara, uma parte do Deserto da Arábia e alguns locais do Deserto de Gobi. Muitos desertos apresentam áreas com vasta vegetação rasteira e suculenta, tais como o agave, os cactos e as gramíneas. Essa vegetação é altamente adaptada ao calor e ao ambiente seco em que vivem, e, dessa forma, extraordinariamente resistente às condições rudes encontradas nas regiões áridas. Embora esteja na moda, no movimento ambientalista, falar da fragilidade do ecossistema desértico, Mainguet (1994) estabelece claramente que o aspecto mais proeminente da vegetação das terras secas (e do solo) é a resistência, e não a fragilidade. Uma medida da degradação da terra é a degradação da vegetação (Dregne, 1983), e um breve exame revela que o estado da vegetação é um poderoso indicador de onde está ocorrendo a degradação adicional e onde irá ocorrer a degradação futura.

A mais importante propriedade das plantas, no controle da erosão, é sua habilidade em conter o fluxo dos agentes erosivos e a energia deles proveniente. Bagnold (1942) discute a habilidade da vegetação em reter a areia. Naturalmente, esta pode ter uma força capaz de destruir a vegetação, 0 suficiente para enterrá-la e matá-la.

2.1.3. Monitorando a desertificação. 
A desertificação não é, tão somente, uma invasão de áreas não desérticas por um deserto central. Sheridan (1981) compara a desertificação a uma guerrilha cujo fronte não tem linha definida. Dregne (1983) descreve-a como um conjunto de terras degradadas, através do abuso humano, e que tenderá a se espalhar continuamente, conforme a progressão do abuso. Um relatório das Nações Unidas (UNEP, 1978) descreve a expansão da desertificação da seguinte forma: "Estes pequenos terrenos degradados, provavelmente uma leve doença, encadeiam todo o processo de áreas extensas." Mainguet (1994) claramente estabelece que a "teoria da intrusão gradual do deserto, a qual tem sido até o momento cientificamente rejeitada, é, todavia, uma idéia fixa na mente de governantes, de proprietários e de jornalistas; isso deve mudar."

A extensão desse "súbito e insidioso processo" (UNEP, 1978) da degradação da terra pode ser difícil de se determinar por observações do solo. Estas podem facilmente mostrar que o solo está exposto em vistas ao cultivo, ou que a salinização está progredindo no solo; entretanto a observação simples não indica o estado da degradação a poucas milhas dali. Cada localidade requer o trabalho humano intensivo, para examinar-lhe a biomassa e realizar a amostragem de solos. Além disso, como indicado por Nelson (1988), o processo de desertificação flutua com o tempo; somente observações repetidas e progressivas são indicadas para determinar a degradação que está ocorrendo e sua localização progressiva. Warren \& Agnews (1988) constatararn que um dos nossos problemas em não compreender a degradação das terras está na "ignorância em estabelecer a direção do movimento e a sua velocidade, uma vez que o movimento e a velocidade requerem exames seqüenciais." Além disso, exames seqüenciais 
são de uso limitado, se as linhas base de comparação não forem estabelecidas (Nelson, 1988; Rodenberg, 1991; Murray et al., 1994).

O sensoriamento remoto por satélites oferece uma forma potencial para examinar todas as regiões áridas do globo. Entretanto o sensoriamento remoto não pode inteiramente suplantar o uso das observações de terra, como foi amplamente suposto nas décadas de 70 e 80 (Mainguet, 1994). Tranqüilamente, o sensoriamento remoto por satélites pode, com as observações de campo, prover um poderoso conjunto pela extensão em tempo e espaço para pontos de uma dada região. O sensoriamento remoto por satélites pode, dessa forma, monitorar grandes áreas em relação às observações pontuais de campo e ajudar no objetivo chave delas. Assim, as observações de campo ficam ancoradas nas observações de satélite; o sensoriamento remoto efetivamente multiplica o valor dos dados adquiridos no campo e identifica a localidade específica onde exames adicionais e repetições de campo sejam necessárias.

Mainguet (1994) cita a importância do "sensoriamento remoto baseado nas verificações de campo para uma melhor percepção da extensão e do processo de degradação." Dregne \& Tucker (1988) indicam 30 a 40 anos de observações por satélites e estudos de campo, requeridos para fielmente determinar qualquer permanente variação nas bordas do deserto de Sahel.

2.2. Degradação e desertificação na Bahia.

O interesse pelos processos de desertificação no Nordeste brasileiro vêm desde algum tempo e é anterior à conferência de Nairóbi. 
Entretanto, a ênfase dada às regiões semi-áridas e subúmidas, pelo Programa das Nações - PNUMA -, levou o Conselho Consultivo da Secretaria Especial do Meio Ambiente a definir as caatingas nordestinas e os cerrados da região Centro-Oeste, como áreas do território nacional onde existem as condições instáveis que parecem evidenciar uma vocação pré-desértica (Barbosa, 1994).

Embora reconhecendo que as regiões áridas e semi-áridas sejam as mais susceptíveis à ocorrência do fenômeno da desertificação, inúmeros estudiosos da questão denunciam processos de degradação da paisagem, em regiões úmidas e subúmidas, mais intensos do que na região semi-árida. Um exemplo é o que vem ocorrendo na fronteira do Rio Grande do Sul (Barbosa, 1994).

Uma vez que os processos de desertificação levam à crescente perda da capacidade dos solos em estocar águas pluviais, que seriam utilizadas no período da estiagem, chega-se à conclusão de que o semi-árido nordestino é a região brasileira mais predisposta ao fenômeno de desertificação, pelas suas características climáticas, posto que a escassez dos totais pluviométricos, as variações interanuais e a duração do período seco dificultam o esforço de recuperação espontânea da cobertura vegetal nas áreas degradadas, cujo grau se acentua a cada período de seca, sempre recorrente (Barbosa, 1994). Por essa razão, os estudos sobre desertificação no território brasileiro foram centralizados na região semi-árida nordestina, onde se insere grande extensão do território baiano.

Nessa área onde se convencionou chamar de "Polígono das Secas", a ocorrência de anos secos, sem periodicidade regular, representa, ainda hoje, um dos graves problemas nacionais. Com efeito, as características do seu meio natural, mais especificamente, a proporção de terras sujeitas aos 
efeitos do clima semi-árido, sempre constituíram um fator determinante da vulnerabilidade econômica da região. Desde o início da colonização do país, tais características justificaram as condições do povoamento e a fragilidade de sua economia, com reflexos diretos nos processos de mobilidade das populações. A região nordestina , semi-árida, tem se destacado, historicamente, por características eminentemente repulsivas. Assim sendo, uma política que conduza ao adequado redimensionamento da sua economia deve, necessariamente considerar os condicionantes naturais (Barbosa, 1994).

A delimitação da região semi-árida nordestina tem sido objeto de inúmeros estudos, com adoção de critérios variados. A delimitação oficial mais antiga data de 1936, quando foi configurado o Polígono das Secas pelo Departamento Nacional de Obras Contra a Seca - DENOCS -, que estabeleceu a isoieta de $600 \mathrm{~mm}$ como limite.

Recentemente, para fins de aplicação dos recursos do Fundo Constitucional de Financiamento do Nordeste - FNE -, foi eleito o índice de $800 \mathrm{~mm}$ de totais pluviométricos médios anuais, como critério para definição da região semi-árida. Vale ressaltar que tais limites são freqüentemente ampliados, quando da ocorrência de secas severas, que atingem áreas subúmidas e extrapolam os limites das regiões semi-áridas propriamente ditas (Barbosa, 1994).

Do ponto de vista geográfico, convém que o critério "seco" ou "úmido" não esteja vinculado a parâmetros exclusivamente quantitativos, arbitrários, de totais pluviométricos anuais. Deve-se estabelecer um elo de ligação com a caracterização ecológica mais ampla, que revele a natureza dos fenômenos climáticos pela interação de elementos e fatores, dentro do quadro regional. Dessa forma, a utilização de Sistemas de Informação Geográficas 
pode caracterizar as condicionantes regionais e aplicar modelos de gerenciamento que permitam uma definição de áreas de ação regional efetiva. Em que pesem estas considerações técnicas, prevalecem, na verdade, os critérios políticos, quando é necessário definir limites para o semi-árido.

As condições mais típicas do domínio das caațingas nordestinas são encontradas no Estado da Bahia, na depressão do Rio São Francisco, sobretudo no trecho baixo-médio do rio, assim como nas depressões formadas pelos trechos médios das bacias dos rios Vaza-Barris, Itapicuru, Paraguaçu e Contas.

Todavia nem toda região semi-árida do território baiano pode ser considerada susceptível ao processo de desertificação, mesmo porque os índices pluviométricos variam espacialmente, entre cerca de $300 \mathrm{~mm}$ e 800 $\mathrm{mm}$ anuais. Além disso, existem os vales úmidos, as encostas e os piemontes, que constituem as famosas paisagens de exceção do sertão nordestino. Assim, no domínio climático semi-árido, diferenciações locais, condicionadas aos solos e ao relevo, criam condições especiais que propiciam a vocação prédesértica e merecem atenção especial.

Sobressaem, por sua vulnerabilidade à desertificação, as áreas recobertas pelos solos Areno-Quartzosos, encontrados em grandes extensões do território baiano: a) na margem esquerda do lago de Sobradinho, constituindo o campo dunário que se estende pelos municípios de Remanso, Casa Nova, Pilão Arcado e Barra; b) na margem esquerda do rio São Francisco, no oeste baiano, ao longo dos eixos de drenagem dos principais rios como o Preto, o Grande, o Branco, das Éguas, o Carinhanha e outros; c) no nordeste baiano, na região denominada Raso da Catarina, estendendo-se até Ribeira do Amparo, na direção sul, e adentrando pelo Estado de 
Pernambuco, na direção norte-nordeste; d) no litoral norte, formando o cordão dunário que se estende de Salvador para os limites com o estado de Sergipe.

Os solos Areno-Quartzosos, apresentam-se, pois, em regiões ecológicas diversificadas, sob condições climáticas que variam desde o clima árido e semi-árido, dominante no norte e nordeste (dunas de Sobradinho e Raso da Catarina), condicionado à cobertura vegetal de caatinga; ao clima subúmido do oeste (eixos de drenagem dos afluentes da margem esquerda do rio São Francisco), com vegetação de cerrado e mata ciliar (veredas e buritizais); e ao clima úmido do litoral com vegetação típica de restingas.

Esses solos são provenientes de depósitos arenosos, resultantes da desagregação de rochas areníticas, muito profundos e excessivamente drenados, com baixa capacidade de retenção de água. Dependendo do clima, podem suportar uma cobertura vegetal densa, como nos eixos de drenagem do oeste baiano. Se desnudados, ficam sujeitos à erosão eólica, oferecendo um risco mais alto de desertificação.

Além dos solos Areno-Quartzosos, são encontrados no nordeste baiano solos de textura média/argilosa, pouco profundos e mal drenados, com baixa capacidade de retenção de água (Planossolos, Vertissolos, Regossolos, Solonetz Solodizado e solos Litólicos) originários do núcleo cristalino do sertão nordestino. São recobertos, em algumas áreas, por seixos e matacões, e as condições de aridez dessa área condicionam a caatinga hiperxerófila, arbustiva, aberta, com formações campestres e com características de parque, constituídos por um tapete de gramíneas, com árvores ou arbustos isolados. Tais áreas oferecem alta vulnerabilidade à desertificação e são submetidas à intensa erosão laminar (hídrica), capaz de remover todo o horizonte superficial do solo, quando da ocorrência das 
chuvas torrenciais. Sua cobertura vegetal sempre foi rarefeita, de porte e biomassa reduzidos, incapaz de condicionar fauna abundante. Supõe-se que processos de desertificação tenham se desencadeado nessas áreas, antes do advento da colonização (Barbosa, 1994).

As áreas em processo de desertificação apresentam fisionomia típica, facilmente identificável nas imagens de satélite ou fotografias aéreas. As características fundamentais, reveladoras do fenômeno, são as manchas de solos expostas que criam uma alta reflectância da luz solar incidente, isto é, um grau elevado de albedo, que sensibiliza as imagens de satélite ou fotografias aéreas, denunciando os núcleos, ou áreas, onde se desenvolve o fenômeno. Tais manchas de solo expostas são denominadas "escaras" e lembram erupções na epiderme (Barbosa, 1994).

Geralmente são áreas onde foi removido todo o horizonte superficial do solo, que se encontra sem capacidade de retenção de água e logo se desidrata, cessadas as chuvas. Nesses núcleos de desertificação, onde o solo já foi todo, ou quase todo, erodido, a vegetação não se recupera, ou se recupera muito lentamente, processo agravado pela deficiência hídrica.

No estado da Bahia, existem alguns domínios pedobioclimáticos onde o processo de desertificação é mais evidente: as áreas das peleo-dunas quaternárias na margem esquerda do lago de Sobradinho, imediações dos municípios de Barra, Remanso, Pilão Arcado e Casa Nova. As areias desse campo dunário constituem um documento importante de um episódio paleoclimático moderno (Quaternário), criador de manchas de aridez mais acentuadas do que as existentes no sertão baiano. Tais areias inconsolidadas são suscetiveis à fácil mobilização, por interferência das ações antrópicas, e são fixadas pela vegetação de caatinga. 
A análise das imagens Landsat revela feições dessas dunas, ora desprovidas de vegetação, ora com vegetação esparsa, mostrando sinais do avanço da erosão eólica, direcional ou aleatoriamente, em distintos graus.

Outra área onde os processos de desertificação podem ser observados são o norte e o nordeste baiano, submetidos a um processo gradual e constante de erosão laminar (hídrica): as partículas finas do solo foram arrastadas pela água, durante o curto período de chuvas intensas e concentradas, peculiares ao clima semi-árido da região; e deixaram como testemunha, as camadas de seixos rolados e de matacões. Tais feições são vistas nos topos, nas encostas dos morros e nas superficies aplainadas, atingindo grandes extensões em Mucururé, Chorrochó e Euclides da Cunha.

2.2.1. Tendências e perspectivas.

As observações, efetuadas nas áreas onde os processos de desertificação já se instalaram, revelam que os sistemas naturais submetidos a esse processo sofrem perdas significativas- total ou parcialmente do solo, da biomassa e da qualidade de vida. Elas tendem a se acentuar e se consolidar, em se mantendo o modelo atual de utilização dos recursos naturais das áreas mais vulneráveis.

As perdas no meio físico podem revelar as seguintes tendências nas alterações das propriedades físicas e químicas do solo: crescente perda da capacidade de retenção de água pelos solos, alta vulnerabilidade às erosões eólica e hídrica, perda de nutrientes, afetando a 
produtividade e a fertilidade dos solos, remoção do horizonte superficial do solo pela erosão.

Quanto à degradação dos recursos hídricos, fatores como a intensificação do escoamento superficial na estação chuvosa, a drenagem intermitente e sazonal, o empobrecimento do lençol freático, o assoreamento generalizado dos talvegues e das barragens, o aumento do carreamento de elementos tóxicos em suspensão e a poluição dos lençóis subterrâneos podem ser citados como tendências futuras.

No meio biológico, as tendências revelam-se nas seguintes perdas: a eliminação da cobertura vegetal nativa e a instalação da exótica invasora, que apresenta características raquíticas; a redução do potencial de biomassa; vegetação esparsa ou ausente, a rarefação da fauna, implicando a destruição dos agentes polinizantes (abelhas e aves), dos quais depende, em parte, a preservação da biomassa; a destruição dos estoques naturais de sementes, reduzindo a capacidade de regeneração espontânea da cobertura vegetal nativa; a perda de recursos genéticos da fauna e da flora.

Tais perdas no meio físico e biológico refletem-se na rentabilidade das lavouras e da pecuária, o que leva ao empobrecimento da região como um todo. A propósito, os fluxos migratórios de saída representam um dos indicadores sócio-econômicos mais seguros dos processos de desertificação. Podem-se considerar, como indicadores demográficos e sócio-econômicos dos processos de desertificação, as seguintes tendências: a diminuição da densidade demográfica, o aumento do número de jovens e velhos, o predomínio da população do sexo feminino, a alta migração de adultos do sexo masculino. 
Quanto a indicadores sócio-econômicos, podem-se citar: a redução da produtividade e da produção agrícola, o aumento de áreas abandonadas, o aumento de desemprego, a redução dos investimentos, o crescimento da importação dos produtos de consumo imediato, a diminuição das fontes de rendas.

Por fim, todo esse quadro de desolação leva à geração de uma consciência de abandono e de desprezo, por parte das instituições governamentais, e a uma atitude de resignação frente aos problemas de sobrevivência (Barbosa, 1994).

Assim, os modelos de simulação no controle e avaliação desses processos podem ser ferramentas fundamentais, tanto no estudo quanto na previsão de ações emergenciais a serem realizadas pelas instituições governamentais.

2.2.2. Cenário desejável.

Para atingir um cenário desejável, o semi-árido nordestino deve ser usado como um ecossistema de produtividade limitada, respeitandose a capacidade de suporte dos seus solos. As áreas que oferecem riscos de desertificação deveriam ser objeto de preservação. Ou, ainda, como se está procurando conduzir o Raso da Catarina, hoje transformado em Reserva Ecológica, objeto de um plano de manejo ecológico específico. Estudos desenvolvidos para a avaliação do seu grau de sensibilidade, face aos fenômenos espontâneos e as intervenções antrópicas, observaram que o Raso

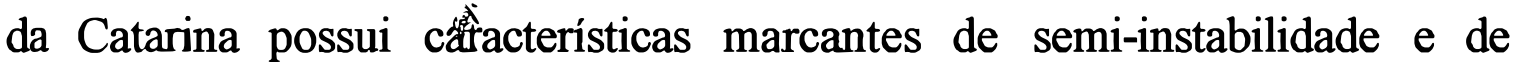


instabilidade morfodinâmica. Entretanto mantém uma cobertura vegetal densa, que impede a ação eólica sobre a camada arenosa, pelo fato de ter sido preservada até hoje. Qualquer atividade antrópica que implique desmatamento poderá destruir radicalmente essa situação precária de semi-equilíbrio (Barbosa, 1994).

O mapa de aptidão agrícola das terras elaborado para o Estado da Bahia, em 1978, pela Superintendência de Planejamento - SUPLAN (BAHIA, 1978), recomenda a preservação da flora e da fauna, não apenas para a Reserva Ecológica do Raso da Catarina, mas para toda a extensão das terras no seu entorno. Além dessa área, indicada para a preservação, todo o norte e nordeste baiano oferecem aptidão regular ou restrita para pastagem natural ou silvicultura, com exceção de pequenas áreas de vocação agrícola. Para as áreas de solo areno-quartzoso do oeste baiano, atribui-se aptidão restrita para silvicultura, enquanto, que para o cordão dunário, litorâneo, é atribuída aptidão regular para a silvicultura.

O cenário desejável, para esses ecossistemas frágeis, de "equilíbrio ecológico instável", será obtido adotando-se as práticas de manejo recomendadas pelos estudos especializados, assim como utilizando-se as terras de acordo com a sua aptidão.

2.3. Aplicação de modelos de simulação superficiais e subsuperficiais da terra, baseados em Sistemas de Informação Geográfica (SIG).

Muitos modelos de erosão dos solos e de poluição não pontual têm tido aplicação em combinação com um Sistema de Informação 
Geográfico - SIG -, para permitir a análise espacial e determinar a capacidade desses novos sistemas computacionais em melhorar e prover informações sobre erosão e poluição, principalmente a partir da década passada.

Modelos matemáticos integram o conhecimento existente dentro de princípios lógicos de procedimentos e de relações (Moore \& Gallant, 1991), e podem ser usados para estabelecer mais conhecimentos sobre os sistemas ambientais, tanto como um meio de testar hipóteses, como de permitir um método para predizer o manejo desses ecossistemas (Beven 1989, Grayson et al. 1992). Muitos modelos ambientais requerem parâmetros de entrada espacialmente distribuídos, porque soluções para a erosão acelerada do solo, para a poluição localizada e para outro problemas ambientais envolvem variações no uso da terra e no seu manejo, para uma inclinação de superficie e uma escala de captação (Moore et al., 1993). A escassez de dados de entrada, para uma resolução espacial preferencial, e a dificuldade de manejar múltiplas entradas, que variam em diferentes formas na paisagem, têm emergido como os maiores obstáculos à aplicação, com sucesso, de modelos de manejo ambiental.

Os SIGs modernos oferecem novas oportunidades para colecionar, armazenar, analisar e expor a distribuição de dados biofísicos e sócio-econômicos espacialmente (Goodchild et al., 1993, 1996). Diversos modelos de erosão dos solos e da poluição localizada têm sofrido modificações e combinações com SIG, para se proverem melhores informações com novas capacidades (Hession \& Shanholtz, 1988; Ventura et al., 1988; De Roo et al., 1989; Petach et al., 1991). O SIG é usado para compilar e organizar os dados de entrada e gerenciar o modelo de saída dessas aplicações; a integração é alcançada pela passagem dos dados entre o SIG e o 
modelo utilizado (Joao \& Walsh, 1992; Wilson et al., 1993), ou pela implantação do modelo no SIG, ou ainda por um sistema de decisão organizado no SIG (James \& Hewitt, 1992; Engel et al., 1993; Romanowicz et al., 1993). Entretanto o software SIG, as bases de dados digitais e os modelos ambientais foram desenvolvidos por diferentes grupos de cientistas (em diferentes tempos e locais) e os beneficios potenciais, bem como as limitações dessa integração são evidentes (Moore et al. , 1993).

2.3.1. Aplicações em modelagem de dados espaciais.

Será apresentado, a seguir, a descrição de seis modelos individuais, os quais enfatizam o requerimento de dados de entrada, o modo como estes dados têm sido obtidos ou gerados com um SIG e a resposta de cada modelo a variações na entrada de dados, uma vez que as aplicações em SIG variam largamente, em termos de métodos, de escalas e de estrutura de dados para a geração de modelos. O parâmetro escala é importante porque determinados grids de parâmetros podem não existir para alguns processos e podem não estar relacionados a medidas pontuais em outros (Binley et al., 1989; Goodrich \& Woolhiser, 1991).

Os seis modelos populares são os seguintes: o USLE (Wischmeier \& Smith, 1978), o ANSWERS (Beasley \& Huggins, 1982), o AGNPS (Young et al., 1987), o CMLS (Nofziger \& Hornsby, 1986), o LEACHM (Wagnet \& Hutson, 1989), e o TOPMODEL (Baven \& Kirkby, 1979). 


\subsubsection{O modelo de simulação USLE.}

A Equação Universal de Perda do Solo - Universal Soil Loss Equation, USLE - é um modelo multiplicativo simplificado, que foi desenvolvido à partir de dados de um evento de 10000 anos (Wischmeier \& Smith, 1978). Os valores dos fatores foram recentemente atualizados, seguindo a análise de centena de novas medidas (Renard et al., 1993), e uma versão revista do modelo substituiu o modelo original para planejamento e conservação de fazendas nos Estados Unidos (Glanz, 1994). O USLE e a Equação Universal de Perda de Solo Revisada - Revised Universal Soil Loss Equation, RUSLE- podem ser escritas como:

$$
A=\text { R.K.L.S.C.P }
$$

onde $\mathbf{A}$ é a perda de solo em toneladas por acre; $\mathbf{R}$, o fator de erosividade da chuva; $\mathbf{K}$, o fator de erodibilidade do solo; $\mathbf{L}$, um fator de comprimento da pendente; $\mathbf{S}$, a porcentagem de inclinação; $\mathbf{C}$, um fator de cobertura e manejo e $\mathbf{P}$ um fator de suporte prático. $\mathrm{O}$ uso da terra e o manejo são representados pela multiplicação entre os fatores $\mathbf{C}$ e $\mathbf{P}$, e podem ser estimados por observações de campo ou por informações de fazendeiros (Wilson, 1989; Busaca et al., 1993). Os valores de C e P podem, também, com alguma dificuldade, ser inferidos de fotografias aéreas, ou de imagens de satélite (Stephens et al., 1985; Ventura, et al., 1988; Fraser et al., 1995). A erosividade da chuva $(\mathbf{R})$ pode ser obtida diretamente da intensidade e do total de chuva. $\mathrm{O}$ valor de $\mathbf{R}$ varia em escala regional. A erodibilidade do solo, valor $K$, pode ser medida ou estimada por qualquer mapeamento de séries de solos. O efeito da topografia e da hidrologia na perda de solo são caracterizados pelos fatores combinados $\mathbf{L}$ e S. 
Diversos trabalhos foram realizados, combinando tal modelo com um SIG, e geraram informações sobre perdas regionais de solos. Hession \& Shanholtz (1988) transformaram o USLE em um modelo baseado em arquivos matriciais e combinaram-no com o Map Analysis Package (Tomilim, 1980) e com uma razão de descarga de sedimentos, para estimar a massa ou peso de sedimentos carreados pelo fluxo de águas de terras agrícolas em Virginia's Chesapeake Bay.

Outros estudos alternativos utilizaram a estrutura de dados poligonais vetoriais em SIG, dos vários planos de informação, e trataram o USLE como um modelo baseado em zonas. Ventura et al. (1988) usaram uma serie de planos de informação poligonais em SIG e um programa em FORTRAN, para estimar a erosão-do solo em Dane County, Wisconsin.

James \& Hewitt (1992) usaram uma série de coberturas ARC/INFO e o programa Arc Macro Language para compilar um sistema suporte de decisão para drenagem do rio Blackfoot em Montana. Seu sistema foi baseado no modelo Water Resources Evaluation of Nonpoint Silvicultural Source - WRENSS -, o qual incorpora uma versão modificada do USLE, para estimar o potencial de erosão do solo.

O SIG foi usado para transformar o USLE em um modelo semidistribuído nestas aplicações. Entretanto existe um número de importantes hipóteses inseridas no USLE, que ajudam a explicar como a aplicação desse modelo para cenários é muito mais dificil que sua aplicação para perda de solo, numa área específica. Essas hipóteses básicas incluem: (1) a deposição de sedimentos (perda ou ganho entre áreas vizinhas) não é representada; (2) cenários podem ser divididos dentro de facetas uniformes; $\mathrm{e}$ 
(3) a runoff ou escoamento superficial é gerado pela forma do fluxo de escoamento.

A primeira hipótese representa o problema prático maior, devido ao USLE não distinguir as partes inclinadas do perfil erodidas e aquelas que sofrem deposição. Césio-137, um radioisótopo produto de programas de teste nucleares atmosféricos, foi usado com sucesso, para documentar os processos de deposição e de erosão em campos, por Ritchie \& Mc Henry (1990).

As duas hipótese finais são também importantes porque elas revelam como o SIG divide o cenário em zonas e como os atributos (planos de informação) são agregados (cruzamentos e estimativas) em cada zona. $\mathrm{O}$ original USLE calcula a perda de solo, ao longo de uma inclinação de perfil definido, em relação a um padrão de perda numa área fixa, e esse padrão pode não ser encontrado em condições naturais (Moore \& Wilson, 1994). Foster \& Wischmeier (1974) dividiram as inclinações irregulares em uma série de segmentos uniformes e modificaram o valor do produto de $\mathbf{L}$ e $\mathbf{S}$ original da equação USLE, para calcular a perda de solo média daqueles perfis de inclinação.

Griffin et al. (1988) rescreveram a equação original do USLE, para calcular a erosão em qualquer ponto de um cenário, e, por isso, invalidaram essas exigências. Sua equação é muito mais fácil de implementar que o modelo original, embora o usuário precise, ainda, distinguir experimentalmente as áreas de erosão e de deposição. Essa versão também conserva a estrutura unidimensional do modelo original (similar aos modelos originais USLE e RUSLE) e não pode manipular variações nas taxas de runoff, causadas pelas taxas de infiltração espacialmente variadas (Kinnell et 
al., 1995) e pela convergência e divergência do terreno (Moore \& Wilson, 1992, 1994; Wilson \& Gallant, 1996).

Nenhuma das aplicações USLE, baseadas em SIG, acima mencionadas, necessitaram distinguir áreas experimentais de erosão e deposição antes da aplicação dessa equação. Não fica claro nem como eles responderam a essas variações e à discussão sobre a escala de trabalho (tamanho de célula matricial e vetor de poligonalização para computar a perda de solo), nem quais as consequiências da utilização de dados em diferentes escalas. Tais aplicações também usaram diferentes gradientes de inclinação e comprimentos em relação àqueles especificados no modelo original; assumiram que a runoff foi gerada uniformemente, ao longo do cenário, e ignoraram a revisão do USLE proposta por Griffin et al. (1988), para a estimativa pontual da erosão (grid de células) no cenário.

\subsubsection{O modelo de simulação ANSWERS.}

O modelo Areal Nonpoint Source Watershed Enviromental Response Simulation - ANSWERS - foi desenvolvido por Beasley e Huggins (1982), para simular o escoamento superficial e a erosão de sistemas de drenagem da água predominantemente agrícola. $\mathrm{O}$ modelo divide o sistema de coleta em elementos quadrangulares (grid de células) e usa a conectividade das células (derivada de valores de inclinação) e a equação da continuidade para a rota de fluxo (Beasley et al., 1982). Três processos de erosão são considerados: a desagregação das partículas do solo, pelo impacto das gotas de chuva; a desagregação de partículas, pelo 
fluxo superficial, e o transporte de partículas pelo fluxo superficial. A quantidade de erosão e de deposição que ocorre em cada célula é estimada e baseada na erodibilidade do solo e no tipo de cobertura da terra da célula, na taxa de fluxo que passa através da célula, e na quantidade de sedimentos no fluxo que passa através da célula (Brown et al., 1993). Um série de elemento da topografia (elevação, inclinação, aspectos), do solo (porosidade, conteúdo de umidade, capacidade de campo, capacidade de infiltração, fator $\mathrm{K}$ do USLE), da cobertura vegetal (porcentagem de cobertura, interceptação, fator CP do USLE, rugosidade superficial, retenção), dos canais (comprimento, rugosidade) e da chuva, como dados de entrada, são requeridos para cada elemento de célula (De Roo et al., 1989).

A versão original do ANSWERS foi limitada a 20 solos espacialmente homogêneos e alguns tipos de cobertura vegetal, devido aos arquivos de entrada terem sido criados na mão (Beasley \& Huggins, 1982; Beasley et al., 1982). A coleção e a organização dos dados de entrada no SIG permitiu que valores únicos fossem utilizados para cada elemento, o nível de agregação espacial é determinado pelo tamanho das células do grid (De Roo et al., 1989; João \& Walsh, 1992). Essa troca fundamental na resolução dos dados e organização do modelo permitiu certas alterações nos resultados: De Roo et al. (1989), por exemplo, concluíram que o ANSWERS previu $46 \%$ a mais em runoff e $36 \%$ a mais em perda de solo, quando uma versão baseada em SIG dividiu uma área total de 4.275 células em grids de 0,01 ha ( $10 \mathrm{~m}$ por $10 \mathrm{~m})$, no lugar do modelo original, para um evento de chuva em Catsop, na Holanda.

Brown et al. (1993) também examinaram a resposta desse modelo a variações nos dados de entrada e nos níveis de agregação, para 
uma bacia de 2.100 há, no piemonte central de Carolina do Norte. Cinco planos de informação de dados em SIG, representando cobertura vegetal, tipo de solo, ângulo de inclinação, aspecto angular e fluxo dos canais, foram preparados e usados com uma série de tabelas-guia, para derivar o modelo de entrada para 23.629 células em grids de 0,1 ha $(30 \mathrm{~m}$ por $30 \mathrm{~m}$ ) (João \& Walsh, 1992). O solo, a cobertura vegetal e o ângulo de inclinação foram, então, generalizados, assumindo-se o valor da classe de maior ocupação da área, dentro de uma agregação unitária celular.

Brown et al. (1993) também implementaram o modelo ANSWERS, com cada conjunto de dados de entrada e um evento de precipitação definido pelo usuário, para produzir uma série de mapas de erosão e de deposição. A erosão e a deposição foram agrupadas em quatro categorias, e a concordância completa entre pares de mapas foi definida como porcentagem, a porcentagem de células transpostas para as mesmas classes de erosão e de deposição. Os resultados mostraram que a melhor concordância ocorreu entre modelos com mais baixo nível de agregação (30 a $60 \mathrm{~m}$ de espaçamento de células); todas as concordâncias entre mapas diminuiram com o aumento nas diferenças entre resoluções; a concordância diminuiu com o aumento no tamanho de células (por exemplo, a 30 e $600 \mathrm{~m}$ foram menos similares).

De Roo et al. (1989) também conduziram múltiplos modelos ANSWERS, para avaliar a sensitividade do escoamento superficial e a predição de perdas de solo, para entradas individuais de solo, cobertura vegetal e canais. Dados de topografia foram computados a partir de modelos digitais de terreno, e os valores dos outros fatores, estimados a partir de observações pontuais de campo, ou de técnicas de interpolação 
geoestatísticas (por exemplo, krigagem em blocos), para um grid espaçado de $10 \mathrm{~m}$. Na aplicação do modelo, usaram dados médios de entrada de solo e de cobertura vegetal para simular uma chuva de 20 minutos, com uma intensidade de $20 \mathrm{~mm}$, em uma porção de 42,7 ha da bacia Catsop. Selecionaram-se cinco valores acima e abaixo dos valores médios, para representar valores possíveis para solos e para vegetação na região, e usados na aplicação de dez modelos adicionais. Um índice de sensitividade simplificado foi criado para descrever as variações dos dados resultantes $\left(\mathrm{RES}_{11}-\mathrm{RES}_{1}\right)$, em torno do resultado médio $\mathbf{R E S}_{6}$, como segue:

$$
S_{\left(V_{1 V 11}\right)}=\left(\operatorname{RES}_{11}-\text { RES }_{1}\right) / \text { RES }_{6}
$$

onde RES $_{1}$ e RES $_{11}$ são os resultados produzidos com o menor e o maior valor usado para cada variável de entrada. O modelo é muito sensível às variáveis infiltração e conteúdo de umidade. Esse é um problema sério, pois essas variáveis têm distribuição ao longo do tempo e do espaço; medidas e interpolações de tais variáveis são difíceis e caras e resultados de estudos individuais podem ser de difícil extrapolação para outras condições de chuva ou bacias, devido às relações entre o modelo de entrada de dados e o modelo resultante não serem lineares e não poderem ser descritas por um único tipo de função.

\subsubsection{O modelo de simulação AGNPS.}

O modelo Agricultural NonPoint Source - AGNPS - é baseado em eventos de simulação do escoamento superficial, de sedimentos, e 
do transporte de nutrientes de bacias agrícolas, compreendendo faixas de terras de uns poucos hectares, a aproximadamente 20.000 ha (Young et al., 1989). O modelo incorpora hidrologia, erosão, transporte de sedimentos e transporte químico em módulos, com a rede de drenagem, a rede de transporte de sedimentos e os outros contaminantes, através de células do contomo de captação até o ponto final de descarga, de forma progressiva, em sua configuração espacial. A escolha do tamanho da célula afeta o tempo e o trabalho requeridos para a aplicação do modelo, como também a sua precisão. Células de 16 ha (400 por $400 \mathrm{~m}$ ) em grid são recomendadas para redes de drenagens maiores que 800 ha. O volume de escoamento, ou runoff, é estimado com o método USDA-NRCS da curva-número, enquanto a erosão superficial, com a versão modificada do USLE (Young et al., 1987). O transporte de sedimentos e a deposição são determinados através das equações propostas por Foster et al. (1981) e Lane (1982), respectivamente. O transporte de elementos químicos é baseado nos algoritmos desenvolvidos para o modelo CREAMS (Frere et al., 1980) e um modelo de avaliação de campo (Young et al., 1982). As várias formas de erosão e a disponibilidade de nutrientes são tratadas como recursos pontuais e adicionadas como contribuições dos recursos difusos. Os resultados do modelo podem ser obtidos para cada célula, ou para cada ponto de descarga final de um conjunto de células.

Engel et al. (1993) fizeram uma ligação entre o AGNPS e o SIG GRASS, como parte de sistema-suporte de decisão, para auxiliar no manejo do runoff, da erosão, e no movimento de nutrientes em terras agricultáveis. O SIG foi usado para organizar os dados de entrada e mostrar o modelo resultante dessa aplicação. Atributos do terreno (gradiente de 
inclinação, comprimento, forma, aspecto, áreas de contribuição morro acima, etc.) representam aproximadamente um terço dos parâmetros de entrada requeridos pelo modelo e podem ser gerados a partir de modelos de elevação digital, ou digital elevation model - DEM. Panuska et al. (1991) usaram uma série de métodos de linhas de contornos, pontos de amostragem do terreno e modelos de elevação digital, para gerar arquivos paramétricos que pudessem ser utilizados com o AGNPS. Eles também examinaram a sensitividade à inclinação, à área de contribuição morro acima e ao fluxo máximo das variáveis associadas ao comprimento dos canais de condução, computados a partir de diferentes modelos de elevação digital, para uma faixa de elementos em uma bacia de 210 ha em North Fork Cottonwood Creek, no sudoeste de Montana. Calcularam o fluxo variado, ao longo dos comprimentos de canais e nas áreas de contribuição, através de métodos de análise de terreno e de elementos de tamanho de células. Panuska et al. (1991) concluíram que a adequação do modelo de elevação digital dependerá das características do terreno, uma vez que o menor tamanho de célula produzirá a melhor precisão de representação do terreno, se a dimensão das células for maior que a resolução horizontal dos dados primários de elevação, e se a diferença de elevação entre os pontos adjacentes for maior que a resolução vertical dos dados. Tais resultados sugerem que terrenos planos, com relevo de inclinação pequena a moderada, serão melhor representados por um modelo de elevação digital que uma bacia dissecada com grutas e ravinas.

Garbrecht \& Martz (1994) também usaram a análise de sensitividade para examinar a dependência de seis propriedades de drenagem (área crítica de nascentes, número de ligações de canais, comprimento total de canais, inclinação média de ligação entre canais, divisor de águas entre 
densidades de drenagem, área de drenagem direta ligada ao canal), em modelo de elevação digital . Eles iniciaram o trabalho com um modelo de elevação digital de $30 \mathrm{~m}$ no centro do Oklahoma, e geraram um modelo de elevação digital grosseiro, por médias espaciais sucessivas. Seus resultados mostraram que o modelo de elevação digital necessita ter uma área de grid menor que $5 \%$ da área de referência de trabalho, ou seja, a área média de drenagem diretamente ligada ao canal, para reproduzir feições de drenagem de importância, dentro de valores de linha de base com $10 \%$ de referência. Isto ocorre porque o modelo de elevação digital não pode acuradamente reprodurir as feições de drenagem que estão com a mesma escala e a mesma resolução espacial. Esses resultados são similares àqueles de Panuska et al. (1991) de forma que pode-se concluir que: (1) o tamanho do grid pode ser selecionado em relação ao tamanho da feição de interesse, e (2) altas resoluções de modelo de elevação digital do terreno são necessárias, se pequenas feições de drenagem são importantes.

\subsubsection{O modelo de simulação CMLS.}

O modelo Chemical Movement through Layered Soil - CMLS - foi desenvolvido por Nofziger \& Hornsby (1986/1987), para simular interativamente movimento químico através do solo, com dados de entrada de solo, química do solo, e atmosféricos. O CMLS divide o solo em 20 camadas e calcula a fração de compostos químicos aplicados remanescente no interior do perfil do solo, além da posição da frente de solutos a diferentes tempos, baseado na teoria do fluxo contínuo de água em sistemas do tipo pistão. As 
propriedades do solo que afetam o movimento químico (densidade, ponto de murcha permanente, conteúdo de água na capacidade de campo e conteúdo de carbono orgânico) podem variar entre camadas, mas são considerados uniformes dentro de cada camada. Duas propriedades químicas (o coeficiente de partição normalizado do carbono orgânico do solo e a meia vida degradativa do elemento químico) e diversos fatores climáticos e culturais conhecidos, que afetam o movimento químico (profundidade do sistema radicular, precipitação diária, irrigação, e totais de evapotranspiração) são também requeridos pelo modelo. Embora esse modelo tenha sido primariamente escrito como uma ferramenta educacional e de manuseio, sua performance tem sido comparada com dados observáveis, de forma favorável, e com modelos de predição de pesticidas em diversas localidades dos Estados Unidos (Pennell et al., 1990; Inskeep et al., 1996). O modelo CMLS tem também sido combinado com o SIG para a predição da qualidade das águas subterrâneas em locais onde é corrente a aplicação de herbicidas (Wilson et al., 1993).

Foussereau et al. (1993) utilizaram uma sub-rotina computacional para gerar uma série de pseudo-perfis de solos, de dados de caracterização pedológica, e avaliaram a incerteza do modelo de predição CMLS, devida à variabilidade dos dados de entrada de subsuperfície do solo em plantios de citros na Florida. Seu método é importante, porque mostra como a variabilidade da maioria dos solos, que ocorrem nas unidades de mapeamento, pode contribuir para a poluição dos lençóis subterrâneos. Cinco centenas de pseudo-perfis foram geradas, para cada unidade de mapeamento do solo, com nome singular (conhecidas as associações) e com três ou mais de conjuntos de dados de caracterizações pedológicas atuais, e combinados 
com dados atmosféricos gerados com WGEN (Richardson \& Wright, 1984), para produzir curvas de probabilidade acumulada, mostrando a fração aplicada de pesticida que lixivia, num perfil de $1 \mathrm{~m}$ de profundidade. Foussereau et al. (1993) compilaram alguns cruzamentos de dados para três unidades de mapeamento da Flórida; mostraram como uma dada unidade de mapeamento pode ter diferentes tipos e porcentagens de solos, a partir da unidade de mapeamento descrita nos relatórios de levantamento. Essa discrepância deixa questões contínuas e de difícil solução; como se pode incorporar perfis hipotéticos que não reflitam as condições reais e de interesse?

Wilson et al. (1996) usaram os modelos WGEN e CMLS, com dois conjuntos de dados de entrada de solos e clima, para avaliar o impacto da resolução dos dados de entrada na predição de modelos, numa área de estudo com $320 \mathrm{Km}^{2}$ em Teton County, Montana. Cinquenta anos de valores de precipitação e de evapotranspiração diária foram gerados e combinados com dados de entrada de solos e de pesticidas, no CMLS, para estimar a profundidade de movimento do herbicida Picloram.

Inskeep et al. (1996) compararam os resultados preditos e os observados para o ácido pentafluorbenzoico (PFBA), para o ácido 2,6 difluorbenzoico (DFBA) e para o Dicamba, por análise temporal, num campo localizado em Manhattan, Montana. Os modelos de predição CMLS e LEACHM (Wagenet \& Hutson, 1989) foram utilizados para medições detalhadas específicas locais (para ambos os modelos); as funções de condutividade e de retenção foram estimadas a partir do banco de dados do USDA-NRCS Soil Survey Geographic - SSURGO -, com o modelo LEACHM; o conteúdo volumétrico de água, estimado a partir de dados 
texturais do banco de dados SSURGO e a precipitação com a evapotranspiração, estimadas diariamente, atraves do gerador WGEN e do banco de dados MAPS, com o modelo CMLS. A comparação dos dados observados e dos simulados mostrou que ambos os modelos LEACHM e CMLS tiveram bom desempenho com dados específicos locais coletados. As predições com CMLS foram menos sensíveis aos dados de entrada que as com o LEACHM, devido ao fato de o modelo CMLS ter uma descrição simplificada do processo de transporte. Inskeep et al. (1996) concluíram que o uso do SSURGO e do MAPS, com CMLS, pode prover uma aproximação razoável para a classificação das unidades de mapeamento, em termos de movimento de solutos, embora o potencial de aplicabilidade dessas aproximações esteja limitado a áreas com cópias digitais do SSURGO e MAPS, ou seja, somente para Montana.

\subsubsection{O modelo de simulação LEACHM}

O modelo Leaching Estimation and Chemstry - LEACHM - é baseado em diferença finita unidimensional e desenhado para simular o movimento de águas e solutos, através de perfis de solo estratificados em camadas ou não (Wagenet \& Hutson, 1989). Sua filosofia é determinística, mecanicista e orientada à pesquisa, com um maior número de variáveis ambientais que os modelos mais simples (Inskeep et al., 1996). O modelo usa uma variável temporal, tendo como base as variações no conteúdo de água, no perfil do solo, a Lei de Darcy e a equação da continuidade, para descrever o fluxo transiente de água; calcula o conteúdo de água e os fluxos para resolver 
a equação de conveç̧ão-dispersão, além de descrever o movimento de solutos, os quais podem ser adsorvidos, volatilizados e degradados. $\mathrm{O}$ modelo também permite estimar a profundidade e o crescimento radicular com 0 tempo, o uso da água (evapotranspiração) e a evaporação (Wagenet \& Hutson, 1989). O LEACHM foi validado e usado como uma ferramenta de previsão para escalas de campo (Wagenet \& Hutson, 1989; Wagenet et al. 1989), e diversas tentativas têm sido realizadas para combinar esse modelo com banco de dados em SIG para escalas regionais.

Petach et al. (1991) usaram LEACHM para simular o movimento de quatro compostos químicos, através de camadas estratificadas de solos, numa área de $70 \mathrm{~km}^{2}$, próxima a Albany, New York. O local foi dividido em grids de células com 0,4 ha de área, e uma série de funções de pedotransferência foram utilizadas para relacionar as propriedades físicas às propriedades hidráulicas, em cada célula. Os solos foram classificados em seis grupos hidráulicos e LEACHM foi executado 25 vezes, usando combinações de diferentes propriedades hidráulicas do solo, para representar a variabilidade espacial esperada nas propriedades hidráulicas. Tal aproximação gerou estimativas da variabilidade dos compostos químicos, abaixo dos intervalos estabelecidos na literatura, e a influência das propriedades hidráulicas do solo na estimativa da variabilidade no processo de infiltração da água. Na lixiviação de elementos químicos, houve aproximadamente a mesma magnitude, sob o impacto dos dois anos de precipitação considerados neste estudo.

A experiência proporcionada pelo estudo acima referido permitiu o desenvolvimento e a aplicação de uma versão, modificada do original para pesticidas, do LEACHM, numa área de $300.000 \mathrm{~km}^{2}$, 
compreendendo os Estados de Connecticut, Maine, Massachusetts, New Hampshire, New York, Rhode Island, e Vermont (Hutson \& Wagenet, 1993). Nesse novo modelo (LEACHA), foram substituídas a equação de Richards, para o fluxo de água, e a equação de conveç̧ão-dispersão, para o transporte químico, pelo modelo adaptado de Addiscott (1977) e Nichols et al. (1982). O modelo LEACHA divide o perfil do solo em camadas horizontais e usa uma variável temporal diária, para calcular fluxos e variações no conteúdo de água e compostos químicos, para cada camada. Os atributos do solo, como o conteúdo de argila, a densidade do solo e o conteúdo de carbono orgânico, foram obtidos à partir do banco de dados STATSGO; as propriedades de retenção hídrica foram estimadas utilizando-se equações de regressão, desenvolvidas por Rawls \& Brakensiek (1982), que relatam a retenção de água em função do tamanho de partículas, da densidade do solo e dos dados de matéria orgânica. Os resultados de aplicações na New England foram mapeados usando quatro classes de potencial de lixiviação; mostraram que 60 a 84 \% da variabilidade na lixiviação podem ser explicados por diferenças no conteúdo de carbono orgânico do solo (Hutson, 1993). Os outros 16 a 40 \% foram relacionados ao clima e a materiais de origem (Wagenet \& Hutson, 1996).

Todos os resultados acima indicam por que conhecimentos adicionais e dados de precipitação e de conteúdo de matéria orgânica do solo podem ser requeridos para melhorar a aplicação, em escala regional, do LEACHA e de outros modelos de transporte de solutos. Os dados de precipitação, usados por Hutson (1993), podem ser melhorados, usando-se um dos novos métodos de interpolação, o qual prediz as variações espaciais da precipitação, com base em dados de estações agroclimáticas e em modelos 
digitais de terreno, ou seja, latitude, longitude, e dados de elevação (Daly et al., 1994; Hutchinson, 1995; Running \& Thornton, 1996). A variável carbono orgânico do solo representa um problema mais dificil, porque os dados de matéria orgânica publicados são muito generalizados e podem não refletir as condições de matéria orgânica para a unidade de mapeamento que está sendo modelada (Wagenet \& Hutson, 1996).

\subsubsection{O modelo de simulação TOPMODEL.}

O modelo TOPMODEL prediz o total relativo e a distribuição espacial e de subsuperficie, do excesso de infiltração e do excesso de saturação do fluxo superficial, com base na superfície topográfica e nas propriedades do solo (Beven \& Kirkby, 1979; Beven et al., 1984; Sivapalan et al., 1987; Quinn \& Beven, 1993). O modelo tem sido validado com dados de precipitação (Beven et al., 1984; Hornberger et al., 1985; Robson et al., 1993; Obled et al., 1994; Wolok, 1995); diversos e recentes estudos têm examinado essa aplicabilidade para problemas de qualidade de água (Wolock et al., 1990; Robson et al., 1992). A popularidade do TOPMODEL pode ser identificada devido a sua simplicidade estrutural e à parametrização parcimoniosa (Iorgulescu \& Jordan, 1994).

$\mathrm{O}$ modelo assume a taxa de recarga espacialmente uniforme e a resposta da subsuperficie, dada pela lei da continuidade, para derivar uma função, relacionando o armazenamento de umidade do solo, ou profundidade do lençol freático, ao índice topográfico $(\ln (\alpha / \tan \beta))$ de uma bacia, de forma a ter-se 


$$
S_{i}=S+m\left\{\lambda-\ln (\alpha / \tan \beta)_{i}-\left[\delta-\ln \left(K_{i}\right)\right]\right\}
$$

onde $S_{\mathbf{i}}$ é o déficit local de umidade do solo; $\mathbf{S}$, o déficit médio de umidade do solo da bacia; m, um parâmetro que caracteriza a redução na condutividade hidráulica com a profundidade do solo; $\alpha$, a área de drenagem por unidade de comprimento de contorno; $\boldsymbol{\beta}$, a inclinação; $\mathbf{K}_{\mathbf{i}}$, a transmissividade lateral do perfil do solo, quando o nível freático intercepta a superfície, e $\lambda$ e $\delta$, os valores médios de $\ln (\alpha / \tan \beta)$ e $\ln (K)$ para a bacia, respectivamente (Zhang \& Montgomery, 1994). Muitas aplicações ignoram o termo transmissividade do solo na equação, porque a transmissividade espacial do solo é pouco conhecida e assume-se ser constante para toda a bacia (Iorgulescu \& Jordan, 1994). A variável $\mathbf{S}_{\mathbf{i}}$ representa o déficit de umidade no solo, de forma que é igual a zero, quando existe saturação completa de umidade, e maior do que zero, quando ocorre déficit de umidade. $\mathrm{O}$ déficit de umidade médio de uma bacia, no tempo $\mathbf{t}, \mathbf{S}_{\mathbf{t}}$, é calculado por

$$
S_{t}=S_{t-1}-\left(q_{t-1}-r\right) \Delta t
$$

onde $\mathbf{q}$ é o total de runoff na bacia no tempo $\mathbf{t}-1$ dividido pela área da bacia; $\mathbf{r}$, a taxa de recarga unitária no interior da coluna de solo e $\Delta \mathbf{t}$, o intervalo de tempo usado para o modelo de simulação. O déficit de umidade do solo, para todos os pontos (grid de células) na bacia, é, então, computado, usando a equação (3). Os caminhos percorridos pela água escoada para fora da bacia são o runoff subsuperficial, em áreas com déficit de umidade do solo maior que a precipitação, adicionada durante o intervalo de tempo estudado; via subsuperficie e infiltração excedente do fluxo superficial, em áreas cuja intensidade de chuva são maịores que a capacidade de infiltração; via subsuperficie e excesso de saturação do fluxo superficial, em áreas com o 
déficit de umidade menor que $\mathrm{o}$ incremento de precipitação no tempo unitário, ou saturadas previamente durante o tempo (Beven et al., 1984) A taxa de fluxo subsuperficial $q_{b}$ da bacia é calculada por

$$
q_{b}=\exp (-(\lambda-\delta)) \exp \left(-S_{t} / m\right)
$$

$\mathrm{O}$ excesso de saturação devido ao runoff $\mathbf{q}_{\mathrm{o}}$, isto é a soma do excesso de umidade e da precipitação direta que ocorre em áreas saturadas, é calculado por

$$
q_{0}=\left(1 / A_{t}\right) \int_{A s}\left(-S_{i} / \Delta t+r\right) d A
$$

onde $\mathbf{A}_{\mathbf{s}}$ é a área da bacia com superficie saturada $\left(\mathbf{S}_{\mathbf{i}}<0\right)$ e $\mathbf{A}_{\mathbf{t}}$, a área total da bacia. Essa aproximação que estabelece a modelagem do conteúdo de umidade médio do solo formará o resultado, de acordo com o índice topográfico; e a previsão da saturação originada na área expandirá ou sofrerá contração, com as variações no balanço de água do modelo (Quinn et al., 1995). O runoff total q, para cada tempo unitário, é a soma do runoff superficial e subsuperficial (Beven \& Kirkby, 1979; Zhang \& Montgomery, 1994).

O índice $\ln (\alpha / \tan \beta)$ foi calculado manualmente, utilizando-se dados de contorno em aplicações mais fáceis do TOPMODEL; o advento do SIG e de técnicas de análises de terreno permitem automatizar o procedimento (Quinn et al., 1995). Entretanto diversos estudos recentes demonstram que modelos espaciais e distribuições estatísticas de índices topográficos variam segundo diferentes resoluções na grade de pontos e com os procedimento de estimação.

Zhang \& Montgomery (1994) calcularam o ângulo de inclinação, a área da drenagem por unidade de comprimento de contorno e o índice topográfico 
para uma série de DEMs de grades quadrangulares, sem depressões, nas escalas de 2, 4, 10, 30 e $90 \mathrm{~m}$; utilizaram a ferramenta de grade em ARC/INFO e dados locais de elevação, obtidos a partir fotografias aéreas de baixa altitude. Eles concluiram que o tamanho da grade do DEM afetou significativamente os parâmetros de computação topográfica e hidrográfica, para duas áreas estudadas, com relevo de moderado a íngreme, no oeste dos Estados Unidos. O espaçamento da grade em $10 \mathrm{~m}$ permitiu uma melhora substancial sobre os dados de $30 \mathrm{~m}$ e $90 \mathrm{~m}$, mas, para os dados de $2 \mathrm{~m}$ e $4 \mathrm{~m}$, permitiu somente uma melhora marginal adicional. Este último resultado pode ter ocorrido em função da escala dos dados ou do método usado para calcular as áreas de drenagem.

Moore (1996) mostrou que o ângulo de inclinação calculado e os valores do índice topográfico variaram com o tamanho da grade, para uma série de 22 DEMs de grade quadrangular, com escalas de 20 a $680 \mathrm{~m}$, em três áreas de estudo com $100 \mathrm{~km}^{2}$, no sudeste da Austrália. Quinn et al. (1995) computaram áreas de drenagem para uma série de $5,10,25$, e $50 \mathrm{~m}$ de elevação, em DEM, a partir de uma escala de contorno de mapeamento com 1:10.000; observaram que pequenos canais e contornos da bacia tendem a ficar obscurecidos ou perdidos com o aumento no tamanho da grade e que uma grade mais larga exibe tendência a valores de índice topográfico mais amplos. Zhang \& Montgomery (1994) e Quinn et al. (1995) concluíram que DEMs, da ordem de $10 \mathrm{~m}$ ou menores, foram necessários para capturar a variabilidade da topografia, e a inclinação das elevações nas áreas de estudo. A evolução continuada e a difusão da ferramenta dos Sistemas de Posicionamento Geográfico - GPS - pode melhorar a coleção de conjunto de 
dados de alta resolução topográfica em alguns ambientes (Spangrud et al., 1995).

A escolha do método de determinação do fluxo pode também afetar a magnitude e a distribuição espacial dos valores ou índices topográficos computados, e alguns programas permitem múltiplas opções. $\mathrm{O}$ usuário TAPES-G, por exemplo, pode selecionar ou o algoritmo D8 (O'Callaghan \& Mark, 1984), ou o algoritmo quase-aleatório Rho8 (Fairfield \& Leymarie, 1991), ou o algoritmo de fluxo de direção múltipla FD8/FRho8 (Freeman 1991, Quinn et al., 1991), ou ainda o algoritmo DEMON de CostaCabral \& Burges (1994) para calcular as áreas de contribuição morro acima (Gallant \& Wilson, 1996).

A escolha do tamanho da grade e do método de distribuição do fluxo afetará a dinâmica do escoamento superficial no TOPMODEL (Wolock \& McCabe, 1994; Quinn et al., 1995). As predições referentes à hidrografia podem não ser alteradas, devido a que as variações na magnitude e na distribuição do índice topográfico serão equivalentes às variações na condutividade hidráulica e à transmissividade lateral, se o modelo for otimizado. Entretanto tais variações afetarão o padrão das variáveis iniciais de área. Esses efeitos são complicados, devido aos canais representarem feições menores que a grade, na parte superior da bacia, e aos métodos usados para manejar as células contendo canais terem consequênncias importantes no delineamento das variáveis de área em torno dos canais e no próprio canal (Quinn et al., 1995).

Morris \& Heerdegen (1989) usaram as áreas de contribuição morro acima como áreas-limite de início dos canais. Gallant \& Wilson (1996) referem-se a esse limite como uma área transversal, com uma série de cotas 
de nível máxima, determinada pelo software TAPES-G. Eles usam esse procedimento como ponto de partida de um múltiplo algoritmo de fluxo (nas partes mais elevadas), derivando para um algoritmo de fluxo simplificado (nas células de canais) para os possíveis caminhos de saída da água, através da bacia. Quinn et al. (1995) utilizaram essa idéia e sugeriram um novo método de cálculo: o índice topográfico em grades de células contendo um canal. Eles também compararam a distribuição do índice topográfico, para uma série de valores sucessivamente pequenos dos limites de iniciação dos canais (CIT), e encontraram variáveis não-representativas da realidade, pela geraçãoincorreta do CIT no conjunto de áreas iniciais. Eles concluíram que existe um limite ótimo para o início do canal e propuseram como esse valor ótimo, o valor de CIT, que causa uma rápida variação na magnitude e na posição do valor de pico da função de distribuição do índice topográfico. Quinn et al. (1995) reconheceram que tal valor de CIT pode não representar a posição verdadeira dos canais, como medidos no campo, mas recomendam que tais valores podem ser definidos para uma resolução de grade particular, procedimento consistente pela ajuda de TOPMODEL e das hipótese analisadas.

Quinn et al. (1995) também introduziram uma combinação entre CIT, com o índice $(\tan \beta)^{\mathrm{h}}$, o qual assume que os canais permanentes são identificáveis, o fator de inicialização usado para estabelecer o particionamento do início do fluxo e o algoritmo de direção do fluxo múltiplo próximo ao divisor de águas da bacia. Este termo varia de acordo com a área de contribuição, para gerar progressivamente fluxos contínuos, próximos ao canal permanente. Eles propuseram a seguinte equação para modelar esse efeito, morro abaixo 


$$
\mathbf{d}_{\mathbf{i}}=\text { cld. } \tan \beta^{\mathbf{f}}
$$

onde $\mathbf{f}=[(\mathbf{A} / \text { tresh })+1]^{\mathbf{h}}: \mathbf{A}$ é a área corrente morro acima; tresh, o valor corrente de CIT admitido pelo usuário, $\mathbf{h}$ o termo de inicialização ajustável, e cld, o comprimento do divisor de águas. Para baixo, o A/tresh resultante tenderá a 1 e o algoritmo do fluxo de múltipla direção será invocado. Como as células aproximam o valor de CIT especificado, um fluxo contínuo ocorrerá. O grau de continuidade dependerá do valor escolhido para $\mathbf{h}$; os valores mais altos gerarão uma variação da direção do movimento do fluxo múltiplo para o fluxo singular acumulado e tenderá a produzir um forte contraste no mapa de índice topográfico. Quinn et al. (1995) sugerem a escolha de valores de tresh e h que aproximem os índices topográficos das observações de campo.

2.4. Modelo de previsão da resposta produtiva dos cultivos à salinidade da água e do solo.

A água de irrigação contém sais dissolvidos, que se acumulam na zona radicular, com a evapotranspiração das culturas (Et), a qual remove a água e deixa os sais na superfície e em todo o perfil do solo. Com quantidades excessivas de sais solúveis, acumuladas na zona radicular, as plantas e as árvores têm dificuldade de extrair água da solução salina aquosa do solo, o que resulta na redução do crescimento e da produtividade das plantas.

A salinidade excessiva pode ser controlada pela aplicação de um total adicional de água de irrigação, chamado requerimento de lixiviação. O requerimento de lixiviação - Leaching Fraction (LF) - 
constitui uma necessidade extra de água, para expressar a lixiviação como uma fração da porcentagem de água aplicada, que penetra no solo (DD). Como definido pelo U.S. Salinity Laboratory (Richards, 1954), é a fração de água de irrigação (DI) que deve penetrar abaixo da zona radicular, para manter a salinidade em um nível específico

$$
\mathbf{L F}=\frac{\mathbf{D D}}{\mathbf{D I}}
$$

O LF varia com a tolerância à salinidade pela cultura e com a salinidade da água de irrigação. Pode referir-se a uma medida quantitativa da salinidade, ou ser determinante no cálculo da lixiviação de sais específicos.

O LF pode ser calculado pela razão entre a condutividade elétrica da água de irrigação (ECwi) e a condutividade elétrica da água de drenagem abaixo da zona radicular (ECwd). Na prática o valor de ECwd não é facilmente mensurável, e o U.S. Salinity Laboratory recomenda utilizar a condutividade elétrica média da solução extraída do solo (ECe) e o ECwi para determinar o LF, de forma que

$$
\mathbf{L F}=\frac{\text { ECwi }}{5(\mathbf{E C e})-\mathbf{E C w i}}
$$

A redução no crescimento das culturas não ocorrerá se um determinado limite for mantido. Caso contrário, verifica-se uma redução linear da produção, em relação ao aumento da salinidade na solução do solo (Sammis \& Herrera, 1996).

A produção de culturas agrícolas, sob condições de salinidade, depende da tolerância das culturas aos sais e da salinidade ná zona radicular, sendo esta determinada pelo LF. As equações de lixiviação 
expressam a salinidade da zona radicular, em termos de salinidade da água aplicada, e o requerimento de lixiviação. A escolha de uma equação particular dependerá de condições localizadas.

Existe uma série de equações que procuram descrever o fenômeno da lixiviação de sais no solo, como a equação de Rhoades (1974)

$$
\frac{\mathrm{Cs}}{\mathrm{Ci}}=0,5 \mathrm{~K}\left(1+\frac{1}{\mathrm{LF}}\right)
$$

onde Cs é a média linear da salinidade do solo na zona radicular (dS/m); $\mathbf{C i}$, a salinidade média da água aplicada ( $\mathrm{dS} / \mathrm{m}) ; \mathbf{K}$, é um coeficiente empírico na equação e $\mathbf{L F}$, o requerimento de lixiviação.

Um outro exemplo é a equação de Bernistein \& Francois (1973)

$$
\frac{<\mathrm{C}>}{\mathrm{Ci}}=\ln \left(1+\frac{1}{\mathrm{LF}}\right)
$$

onde $<\mathbf{C}>$ é a salinidade média na zona radicular $(\mathrm{dS} / \mathrm{m}), \mathbf{C i}$, a salinidade média da água aplicada, e o $\mathbf{L F}$, o requerimento de lixiviação.

Uma equação que também utiliza o requerimento de lixiviação (LF) e os parâmetros de salinidade do solo é a equação de Hoffman \& Van Genuchten (1983)

$$
\frac{C s}{C i}=\frac{1}{L F}+\left(\frac{\delta}{z} L F\right)\left\{\ln \left[L F+(1-L F) \exp \left(\frac{z}{\delta}\right)\right]\right\}
$$

onde Cs é a média linear da salinidade do solo na zona radicular (dS/m); $\mathbf{C i}$, a salinidade média da água aplicada $(\mathrm{dS} / \mathrm{m}) ; \delta / \mathbf{z}$, uma relação empírica e LF, o requerimento de lixiviação.

O modelo descritivo desenvolvido por Prendergast (1993) para quantificar os efeitos da salinidade da água de irrigação na produção das 
culturas é ilustrado na Figura 1. Condições de fluxo contínuo são assumidas, e toda a quantidade de água, foi expressa como lâmina aplicada.

A concentração de sais da água salina aplicada (Ci ), em $\mathrm{dS} / \mathrm{m}$, para o modelo, pode ser determinada pela salinidade média da água de irrigação e da chuva infiltrada, onde a chuva tem distribuição espacial e temporal, durante a estação de crescimento da cultura. A Ci pode ser calculada como

$$
C i=\frac{[(R-R o) \cdot C r+W \cdot C r]}{(R-R o+W)}
$$

onde $\mathbf{R}$ é a chuva durante a estação de crescimento (m); Ro, é a chuva escoada superficialmente $(\mathrm{m}) ; \mathbf{C r}$, a salinidade da chuva $(\mathrm{dS} / \mathrm{m}) ; \mathbf{W}$, a lâmina de irrigação (m), e Cw, a salinidade da água de irrigação infiltrada $(\mathrm{dS} / \mathrm{m})$.

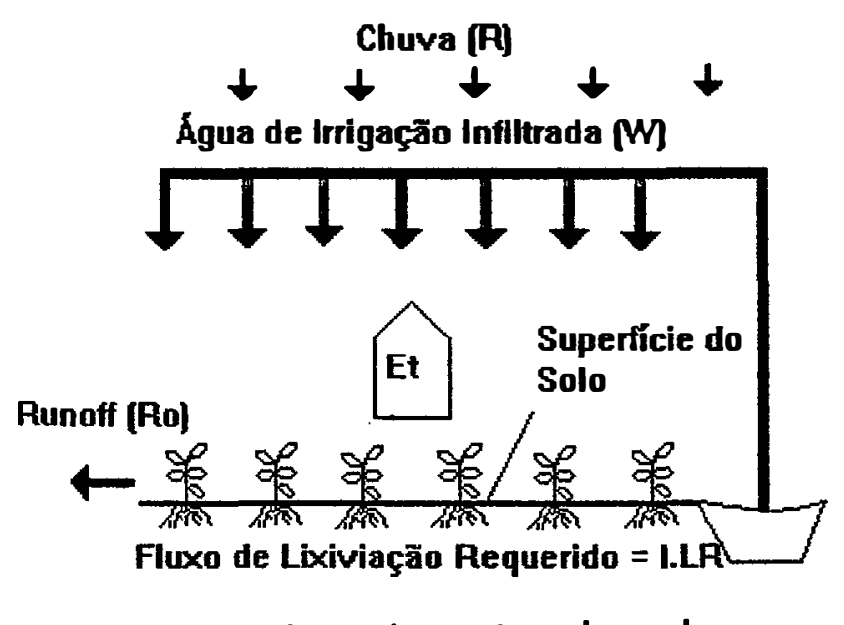

Figura 1 - Modelo representativo para culturas irrigadas. As águas que entram são de chuva e de irrigação, então utilizadas pelas culturas como evapotranspiração, ou como instrumento de lixiviação, abaixo da zona radicular. Alguma chuva é perdida por runoff (Prendergast, 1993). 
A lâmina de irrigação requerida depende do uso da água pela cultura, a qual pode ser estimada para um máximo de produção. Esse máximo de produção é alcançado quando a evapotranspiração atual (ETa) for igual à evapotranspiração máxima (ETm). As medidas de evapotranspiração são determinadas a partir da evaporação de tanque classe A (Ep), multiplicada por um coeficiente de tanque de 0,85 e um coeficiente de cultura (Kc) (Doorembos \& Kassam, 1974), de forma que

$$
\mathbf{E T m}=0,85 \text {. Kc. Ep }
$$

$\mathrm{O}$ efeito da salinidade da água pode ser estimado por uma faixa de níveis de salinidade na zona radicular. Alguns deles resultarão na redução da produção e na redução do uso da água pela cultura. A redução na evapotranspiração pode ser razoavelmente estimada pela hipótese de que o uso da água está linearmente relacionado à produção ( Doorembos \& Kassam, 1974; Hanks, 1974; Stewart et al. 1977), que é,

$$
\left(1-\frac{\mathbf{Y a}}{\mathbf{Y m}}\right)=\text { Ky. }\left(1-\frac{\mathbf{E T a}}{\mathbf{E T m}}\right)
$$

onde Ya e Ym são a produção atual e máxima e Ky, um fator de resposta de produção. Uma maior sensitividade da produção ao stress hídrico ocorre com valores altos de $\mathbf{K y}$.

Prendergast (1993) desenvolveu uma equação geral que permite estabelecer a resposta relativa de uma determinada cultura à salinidade da água de irrigação considerando diferentes LF. A equação engloba alguns dos conceitos anteriormente mencionados, de forma que 


$$
\begin{aligned}
& Y=1+0,01 * B * A-0,002 * B * K *\left(1+\frac{1}{L F}\right) \\
& *\left[\mathrm{Cw}-\frac{(\mathrm{R}-\mathrm{Ro})(\mathrm{Cw}-\mathrm{Cr}) \mathrm{Ky}(1-\mathrm{LF})}{0,85 * \mathrm{Kc} \mathbf{c}^{*} \mathrm{Ep}^{*}(\mathrm{Y}+\mathrm{Ky}-1)}\right]
\end{aligned}
$$

onde $\mathbf{Y}$ é a produção relativa da cultura; $\mathbf{B}$, a redução de produção fracionária por unidade de aumento da salinidade, na zona radicular (dS/m); A, o limite de salinidade na zona radicular de produção de uma cultura na equação de Maas e Hoffman (1977) (dS/m); K, o coeficiente empírico da equação de lixiviação de Rhoades (1974); Cw, a salinidade média da água de irrigação (dS/m); $\mathbf{R}$, a lâmina de chuva durante a estação de crescimento (m); Ro, o escoamento superficial ou runoff $(\mathrm{m}) ; \mathbf{C r}$, a salinidade da água de chuva $(\mathrm{dS} / \mathrm{m})$. Os outros parâmetros foram anteriormente definidos.

Este último modelo, que estabelece uma relação entre as variáveis ambientais e os aspectos produtivos, relacionados aos cultivos, encerra alguns dos principais mecanismos de determinação matemática disponíveis na atualidade, de forma a estabelecer, de modo espacial e temporal, o processo de degradação das terras sujeitas a problemas de salinização. No tópico seguinte, verificam-se alguns procedimentos em sensoriamento remoto, que auxiliam no teste de hipóteses dos modelos anteriormente mencionados.

2.5. Sensoriamento remoto no estudo da vegetação e dos solos salinos.

É essencial o desenvolvimento de técnicas para monitorar o local onde a degradação está ocorrendo e para de finir quais áreas apresentam 
maior risco de degradação, devido à erosão. A eficiente e acurada mensuração da cobertura vegetal de regiões áridas é a chave para a resolução do problema. Além disso, o conhecimento preciso da cobertura vegetal, em regiões áridas, permitirá uma melhor contenção dos fluxos hidrológicos. Plantas de regiões áridas são bem adaptadas ao calor, ao ambiente seco no qual elas vivem e tais adaptações, desenhadas para conservar a água e prevenir seu secamento, têm importantes conseqüências na reflectância, nas regiões, do visível e do infravermelho. Essas adaptações e variações dramáticas no tempo, e entre espécies, fazem com que índices padrão de vegetação sejam imprestáveis para determinações quantitativas. Este capítulo demonstrará que uma das características espectrais singulares da vegetação de regiões áridas é a necessidade de mais alta resolução espectral de dados para monitoramento, em relação a regiões úmidas, e identificará partes específicas do espectro a serem enfatizadas nos índices de vegetação, harmonizando-os para regiões áridas.

\subsection{1. Índices de vegetação}

A seção seguinte aborda as feições espectrais básicas da vegetação verde e descreve como os índices de vegetação, usando-se dados de sensoriamento remoto em bandas largas, foram desenvolvidos. 

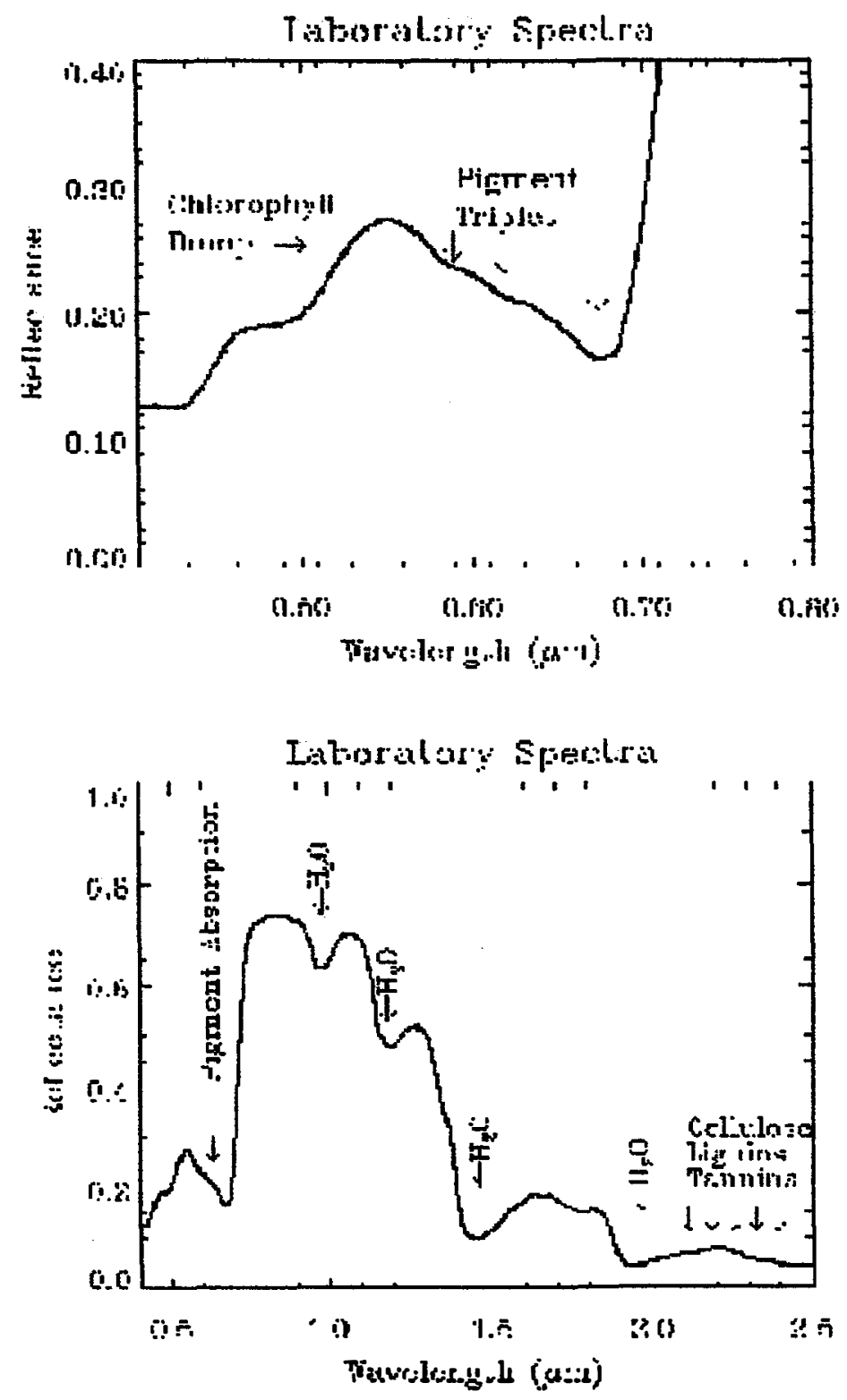

Figura - 2 Espectro típico da vegetação verde. O gráfico superior é uma ampliação da região retangular no gráfico inferior. Observe como a adsorção dos pigmentos na região do visível é causada por um "triplet of pigment" três pigmentos adsortivos. A forte reflectância para a faixa de $0,8-1,2 \mu \mathrm{m}$ é causada pela forte reflexão das células paliçádicas. A água nas folhas é o mais importante absorvente próximo a 1,0 $\mu \mathrm{m}$, mas diversas plantas têm significativa absorção entre 2,0 - 2,5 $\mu \mathrm{m}$ (Gates et al., 1965). 
Os trabalhos em propriedades espectrais de plantas começaram próximo ao ano de 1913 e relataram que a luz, ao penetrar as folhas, é criticamente refletida, na sua porção interna, pela parede de células onde ocorrem variações do índice de refração em relação à água $(1,33)$ e em relação ao ar $(1,00)$. Isso conduz a uma mais alta eficiência de dispersão (espalhamento) de todos os comprimentos de onda da luz. Gates et al. (1965), em seus trabalhos iniciais, relatam as propriedades espectrais das plantas para a faixa entre o ultravioleta e o infravermelho termal. $\mathrm{O}$ trabalho resume as faixas de absorção de alguns componentes chave das plantas. A Figura 2 mostra o espectro de reflectância típica de folhas verdes na faixa espectral do visível e próximo ao infravermelho médio $(0,4 \mu \mathrm{m}-2,5 \mu \mathrm{m})$. Pigmentos de plantas, tais como a clorofila, absorvem fortemente a luz no espectro do visível, a água, no estado líquido, nas folhas das plantas, absorve a luz nos comprimentos de onda maiores que $1,4 \mu \mathrm{m}$.

Muito da atenção em sensoriamento remoto de vegetação verde é focado no forte contraste de reflectância entre o visível e o infravermelho próximo (NIR), os quais formam fortes degraus, no espectro da borda vermelha. Na Figura 3, o espectro do solo é compilado para comparação com o espectro das folhas verdes. Observe que existe alguma diferença no espectro do solo no vermelho e infravermelho próximo, sendo a reflectância do infravermelho próximo sendo um pouco mais alta.

Entretanto, em regiões semi-áridas, as respostas da vegetação verde sofrerão variações, de acordo com o período e a época de aquisição, uma vez que tais respostas relacionam-se diretamente ao período chuvoso. 
Logo, esses degraus deverão ser menores, pela proximidade das respostas nas duas bandas.

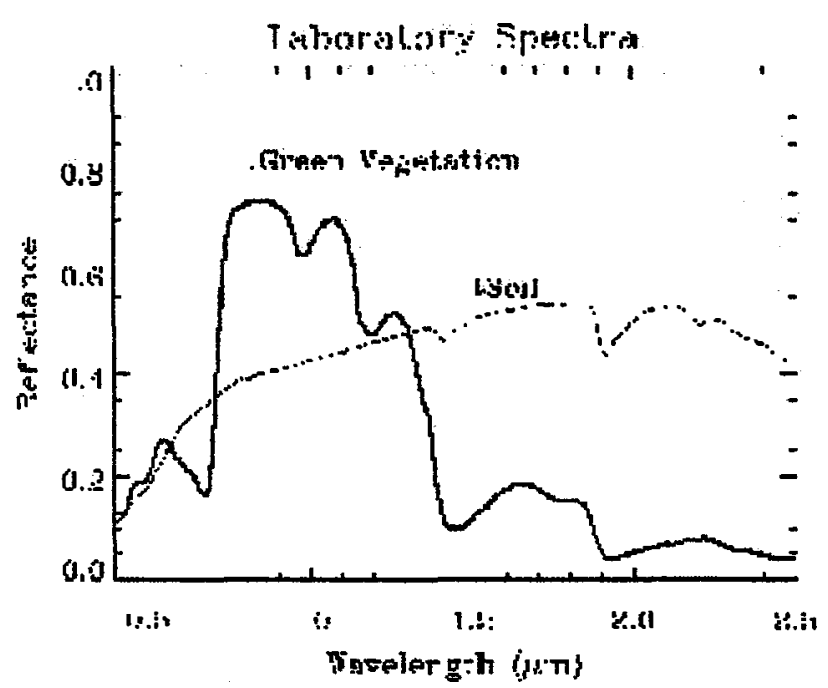

Figura 3 - Espectro da vegetação verde e do solo para a faixa de $0.4-2.5$ $\mu \mathrm{m}$. Observe como a variação na reflectância entre o visível e o infravermelho próximo é muito menor para o solo em relação a vegetação (Gates, et al., 1965).

Uma conseqüência do espectro distinto da vegetação verde é mostrada na Figura 4. O eixo inferior, à direita da nuvem de pontos, forma um contorno, geralmente identificado como a linha de solo. Existe também um pico para o lado oposto da linha de solo, devido a uma elevada reflectância no infravermelho próximo e a uma reflectância relativamente fraca do vermelho, característica da vegetação verde; esse ponto é definido como ponto de vegetação verde. Pontos parcialmente cobertos pelas plantas verdes, e parcialmente cobertos pelo solo, são compilados entre os dois extremos. Esta figura foi denominada por Kauth e Thomas (1976) como um tasseled capagram, ou a cobertura em forma de cacho soltos de fios. 


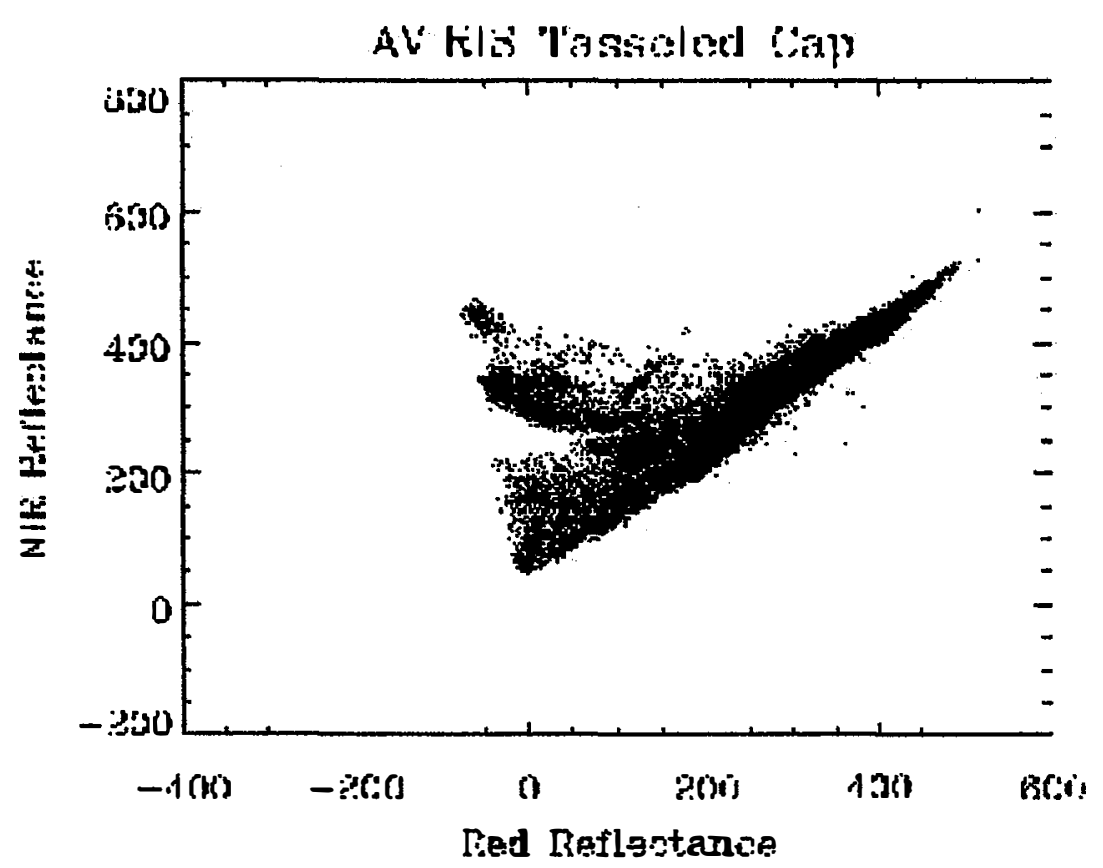

Figura 4 - Neste diagrama, as reflectâncias NIR $(0.755 \mu \mathrm{m})$ e red $(0.674$ $\mu \mathrm{m})$ (normalizadas para 1000) foram compiladas para cada pixel por uma imagem AVIRIS. A linha abaixo é referida como a linha de solo. O pico na direção oposta da linha de solo, o qual apresenta alta reflectância NIR e baixa reflectância red, é referido como linha de vegetação. O restante cobre estes dois extremos.(Kauth \& Thomas, 1976).

Estas são as duas aproximações gerais, feitas para determinar índices para mensuração da cobertura vegetal, baseadas nas características do dossel. A primeira aproximação mede a distância entre o pixel compilado na nuvem de pontos e a linha de solo. A linha de solo é usada pela facilidade em relação ao ponto vegetativo de $100 \%$. O índice perpendicular de vegetação (PVI) de Richardson e Wiegand (1977) assume que a distância perpendicular do pixel para a linha de solo é linearmente relacionada a cobertura vegetal. Este índice é calculado como segue:

$$
\text { PVI }=\operatorname{sen} \alpha(\text { IIR })-\cos \alpha(\text { red })
$$


onde NIR é a reflectância no infravermelho próximo; red, a reflectância no vermelho e $\alpha$, o ângulo entre a linha de solo e o eixo infravermelho. Dessa forma, tem-se que linhas de isovegetação (linhas de igual vegetação) deverão todas ser paralelas à linha de solo. Um caso especial, nesse sentido, é o índice de vegetação (VI) mencionado por Lillesand e Kiefer (1987), batizado de índice da diferença de vegetação (DVI) por Richardson e Everitt (1992):

$$
\text { VI }=\text { DVI }=\text { NIR }- \text { red }
$$

Este caso ocorre quando a linha de solo tem inclinação igual a 1,0.

A próxima possibilidade é assumir que as linhas de isovegetação convergem para um ponto singular. Como uma primeira aproximação, Jordan (1969) desenvolveu o índice de vegetação racional:

$$
\mathbf{R V I}=\frac{\text { NIR }}{\text { red }}
$$

RVI não é, geralmente, utilizado em sensoriamento remoto. $O$ índice utilizado é o índice de vegetação da diferença normalizada (NDVI). Ele é funcionalmente idêntico ao RVI e pode ser escrito como:

$$
\text { NDVI }=\frac{\text { NIR }- \text { red }}{\text { NIR }+ \text { red }}=\frac{\text { RVI }-1}{\text { RVI }+1}
$$

Ambos os índices, RVI e NDVI, basicamente medem o ângulo de inclinação da linha entre a origem do espaço red-NIR e o valor red-NIR do pixel da imagem. A diferença entre RVI e NDVI é a faixa de valores que os dois indicam. A faixa de $-1,0$ a 1,0 para o NDVI é mais fácil de trabalhar, em relação à faixa infinitesimal do RVI. O NDVI pode ser considerado um fator que melhora o DVI, pela eliminação do efeito do albedo de banda-larga redNIR, através da normalização. Crippen (1990) reconhece que a radiância red, 
subtraída no numerador do NDVI é irrelevante e formulou o índice infravermelho de porcentagem de vegetação (IPVI):

$$
\text { IPVI }=\frac{\text { NIR }}{\text { NIR }+ \text { red }}=\frac{1}{2}(\text { NDVI }+1)
$$

O IPVI é funcionalmente equivalente ao NDVI e ao RVI, mas tem uma faixa de valores entre 0,0 e 1,0. Este índice também elimina uma operação, por imagem pixel, importante para o rápido processamento de grande volume de dados. Huete (1988) sugeriu um novo índice de vegetação, desenhado para minimizar o efeito do solo, o qual ele chamou de índice de vegetação soloajustado. Este índice de vegetação tem a seguinte formulação:

$$
\text { SAVI }=\frac{\text { NIR }- \text { red }}{\text { NIR }+ \text { red }+\mathrm{L}}(1+L)
$$

Huete coletou evidências de que as linhas de isovegetação não convergem para um ponto singular. Ele selecionou o fator $\mathbf{L}$ em SAVI, baseado em linhas, onde uma específica densidade de vegetação intersecta a linha de solo. O resultado final é um NDVI, no qual uma origem não é o ponto de reflectância zero red e zero NIR. Para coberturas vegetais densas, o valor de L é 0 , e 1 para coberturas vegetais pobres. Para vegetação intermediária $\mathrm{L}=0,5$, o valor mais intensamente utilizado.

Qi et al. (1994) desenvolveram um índice de vegetação, que é basicamente uma versão do SAVI, onde o fator $\mathbf{L}$ é dinamicamente ajustado, usando-se os dados da imagem. Ele se referiu a esse índice como o índice de vegetação solo ajustado modificado (MSAVI). O fator $\mathbf{L}$ é dado pela seguinte expressão:

$$
\text { L = 1 }-2 \times \text { inclinação } \times \text { NDVI } \times \text { WDVI }
$$


onde WDVI é o Weighted Difference Vegetation Index de Clevers (1988), o qual é funcionalmente equivalente ao PVI e calculado como segue:

WDVI = NIR - inclinação $\times$ red

A variável inclinação, usada em ambas as equações precedentes, é a inclinação da linha de solo, a qual é determinada como descrito acima. Qi et al. (1994) também criaram uma segunda versão deste índice de vegetação, o qual chamou de MSAVI2:

$$
\text { MSAVI2 }=\frac{1}{2}\left(2(\mathrm{NIR}+1)-\sqrt{(2 \times \mathrm{NIR}+1)^{2}-8(\mathrm{NIR}-\mathrm{red})}\right)
$$

Note-se que todos esses índices de vegetação usam somente duas bandas red e NIR (vermelha e infravermelha próxima).

Uma importante dificuldade, encontrada quando utilizam os índices de vegetação, no sentido de minimizar o efeito de variação devido ao solo, é um aumento na sensitividade a variações atmosféricas (Leprieur et al., 1994; Qi et al., 1994). Foram realizadas aproximações no desenvolvimento de índices de vegetação, os quais são menos sensíveis à atmosfera, tais como Atmospherically Resistant Vegetation Index (ARVI), de Kaufman e Tanré (1992) e o Global Enviromental Monitoring Index (GEMI) de Pinty e Verstraete (1991). Qi et al. (1994) demonstraram que um distúrbio no espectro de reflexão, devido ao solo que torna obscuro ou reduz a qualidade de um sinal, provocado por GEMI, inutiliza as emissões de baixa cobertura vegetal, de forma a que todos os índices de vegetação, desenhados para minimizar o efeito da atmosfera, aumentam a sensitividade ao solo, de modo a torna-los completamente inutilizáveis para regiões áridas.

Existem, entretanto, outros especialistas desenvolvendo índices de vegetação, a partir de duas combinações de bandas outras, que não 
NIR-red. Pickup et al. (1993) propuseram um índice similar ao PVI, utilizado para as bandas MSS 4 e 5. Embora Pickup et al. (1993) afirmem que tal índice foi altamente efetivo para a deteç̧ão da vegetação seca e verde, essa combinação de bandas mostra-se sensível às feições de absorção dos óxidos de ferro, presentes em muitos solos. A deteç̧ão de vegetação seca e verde, com esse índice, chamado de PD54, provavelmente se deve ao fato de que a cobertura de vegetação se mostra obscura nessas feições, as quais, contudo, podem variar muito em diversos solos devido a anisotropia.

Jackson (1983) mostrou como um conjunto de $n$ bandas pode ser usado para construir um índice de vegetação perpendicular. $O$ procedimento básico é escolher dois ou mais pontos de solo, para definir a linha de solo no $n$-espaço, e então utilizar a ortogonalização Gram-Schmidt para encontrar a greenness, a linha verde aproximada, a qual passa através do ponto de cobertura vegetal $100 \%$ e é perpendicular à linha de solo. Dois índices, ambos conhecidos como Green Vegetation Index, têm considerável uso. Um GVI para quatro bandas, para dados MSS, foi desenvolvido por Kauth e Thomas (1976), e uma versão de seis bandas foi desenvolvida para dados TM, por Crist e Cicone (1984).

2.5.2 - Aplicações do sensoriamento remoto no estudo da salinidade dos solos.

Nesta seção, a ênfase recairá sobre trabalhos aplicados, de modo a subsidiar a metodologia a desenvolver na bacia do rio Salitre. Embora 
existam trabalhos aplicados, na área de sensoriamento remoto, voltados para 0 estudo da degradação dos solos por efeito da salinidade, pode-se dizer que os números são inexpressivos, em relação a gravidade do problema.

Pode-se, ainda, estabelecer que, ao final do século 20, esse problema encontra-se sem solução, e que os investimentos em pesquisa nessa direção são reduzidos ou inexistentes. Acena-se, com este trabalho, para a possibilidade de um estudo preliminar, no estabelecimento de subsídios iniciais para o desenvolvimento de trabalhos mais efetivos no futuro.

Para as condições do semi-árido nordestino, é de fundamental importância a aplicação de recursos para desenvolvimento de pesquisa na área, o mais rápido possível.

2.5.2.1. Sensoriamento remoto para estudo da degradação das terras.

Informações precisas sobre a natureza, a extensão, a distribuição espacial e a magnitude do problema da degradação das terras constituem os subsídios vitais para a recuperação, a conservação e o manejo científico dessas terras. Faz-se, também, necessário monitorar as terras degradadas a intervalos regulares de tempo, para se conhecer o impacto das medidas de recuperação e conservação implementadas.

$\mathrm{Na}$ interpretação e na análise de dados de sensoriamento remoto, para a extração de informações sobre degradação de terras, utilizamse geralmente os métodos da análise digital e da interpretação visual . A 
interpretação visual envolve identificação e delineamento das terras degradadas, que são manifestadas em composições coloridas em falsa cor false color composite (FCC) -, baseadas em elementos da imagem tais como tamanho, forma, textura, tom, matiz e associações.

A reflectância espectral das terras degradadas forma a base da análise digital. Os dados de sensoriamento remoto, em sistemas de armazenamento compatíveis de computador, são analisados com a ajuda de softwares analisadores de imagem.

Além desses procedimentos, é necessário o trabalho representativo de amostragem de áreas no campo, selecionadas segundo vários graus de degradação . Durante a visita de campo, informações gerais das feições do terreno e das características locais são coletadas; realizam-se estudos de perfis e coletam-se amostras de solo para análise. Os mapas preliminarmente interpretados são, então, modificados, à luz dos dados de campo e dos dados analíticos dos solos e, dessa forma, mapas finais são preparados, com legendas apropriadas.

Os solos afetados por sais têm distinta expressão em composições FCC de imagens de satélite, apresentando-se como pequenos pontos de uma cor de reflectância intensa, num fumdo vermelho brilhante ou de tons magentos caracteriza a vegetação (Venkataratnam, 1994). Nesse caso, pode-se assumir um processo de degradação localizada, com vegetação em torno da área de ocorrência. Os solos afetados por sais, com pobre crescimento de cultivos, aparecem em tons vermelho ofuscado ou tom matizado que permitem o seu mapeamento.

No trabalho de cruzamento de informações, para a análise digital e a obtenção de um mapa de susceptibilidade, Venkataratnam (1994) 
cruzou dados de erosão do solo, declividade, uso da terra, tipo de cobertura e características do solo. Assim, na análise digital, pôde estabelecer a natureza, a magnitude e a extensão do problema, nos seus diversos níveis, e comparálos com os dados em FCC. As informações derivadas, nos vários aspectos da degradação da terra, através de dados de sensoriamento remoto, de métodos convencionais e de pesquisas são armazenadas na base de dados computacionais; a análise de dados é realizadas sobre princípios científicos, em SIG, de forma a subsidiar o planejamento de sistemas de recuperação e de conservação para o incremento da atividade produtiva sobre bases sustentáveis (Venkataratnam, 1994).

Rahman et al. (1994), utilizando dados do satélite SPOT e campos selecionados por suas condições salinas e sódicas, trabalharam na deteç̧ão da salinidade e na deficiência de nutrientes, estabelecendo relações entre as análises estatísticas dos dados de campo e aquelas obtidas nos dados de satélite.

Para interpretação visual, Rahman utilizou FCC, nas bandas 1, 2 e 3 do SPOT, à escala de 1:16.500. Foram usados alguns índices computacionais para a análise com os dados de campo, tais como, o índice de brilho - "brightness index" (BI) -, ou seja, a soma das bandas verde, vermelha e infravermelho próximo (grn + red + NIR), o índice da diferença normalizada NDVI e o índice racional RI (Rahman et al., 1994).

Dessa forma, concluíram que nas imagens em FCC da área estudada, as áreas salinas aparecem como pontos brilhantes em, branco, ao passo que a vegetação saudável apresentou tons entre o vermelho brilhante intenso e o magenta e os corpos de águas profundos registraram tons de azul escuro. A interpretação visual da imagem FCC não indica, quantitativamente, 
nem a salinidade, nem o problema da deficiência de nutrientes. Altas correlações entre XS-3 (banda do infra vermelho próximo), com ECe (condutividade elétrica do extrato de saturação), e o sódio solúvel em água indicaram que o espectro infravermelho é superior ao espectro visível, para a detecção da salinidade do solo. O BI, NDVI e o RI foram capazes de diferenciar as áreas salinas. As análises de variância mostraram que grupos de amostras, possuindo altos valores de BI, tiveram, de forma significativa, altas ECe, $\mathrm{Na}^{+}$solúvel em água, $\mathrm{Ca}^{2+}, \mathrm{Mg}^{2+}$, e baixos conteúdos de zinco e manganês. Os pontos de amostragem de baixo NDVI e NIR/red tiveram mais elevada ECe e sódio solúvel em água, de forma significativa (Rahman et al., 1994).

Um estudo foi conduzido, no sudoeste do Texas por Everit et al. (1988), para avaliar o potencial do imageamento de vídeo - video imagery -, para distinguir solos salinos em ambientes agrícolas. $\mathrm{O}$ objetivo deste estudo foi o de avaliar o potencial das imagens de vídeo na determinação de solos salinos em três campos distintos: faixa de terra nativa, pastagens e terras áridas de cultivo, utilizando-se a classificação dos solos salinos pelo modelo de Richards, (1954).

Entre as conclusões do trabalho de Everitt, citem-se: os locais salinos distinguem-se nas bandas do verde e do infravermelho próximo, mas são mais claramente distintos na imagem vermelha; a habilidade em distinguir solos salinos e não salinos foi primariamente atribuída à menor cobertura de plantas nos solos salinos; a superfície de encrostamento, presente nos solos salinos, ajudou também nessa distinção, uma vez que os solos não salinos apresentam rugosidade superficial; entretanto, mesmo utilizando-se técnicas 
computacionais, o modelo foi incapaz de distinguir estradas de solos salinos (Everitt et al., 1988).

Os exemplos anteriores mostram aspectos de distinção, no nível de campo, de características inerente aos solos afetados por sais. Tais características podem subsidiar o trabalho de aquisição das informações, como também servem de exemplos para trabalhos futuros.

Entretanto são modelos relativos. Apresentam uma análise instantânea e não realizam a discussão temporal do fenômeno. A salinidade é um fenômeno que ocorre com o tempo e a análise de aspectos produtivos, fisiológicos e temporais parece de fundamental importância no estabelecimento de conclusões úteis aos projetos de manejo, conservação e recuperação.

O trabalho de Wiegand et al. (1992) sinaliza para uma análise mais dinâmica e procura estabelecer relações entre medidas específicas de terra (solos) e observações espectrais, para três sistemas individuais de campo; busca além disso, determinar correlações entre sistemas de dados, para amostras locais comuns, e produzir mapas de salinidade, por classificação espectral não supervisionada, a partir de mapas baseados nas equações estimativas de condutividade elétrica desenvolvidas para correlação entre amostras espectrais locais e as de salinidade.

Como método, Wiegand et al. subdividiram o trabalho em quatro etapas: amostragem de campo, dados espectrais, extração de dados digitais e análise de dados.

$\mathrm{Na}$ amostragem de campo, as áreas foram subdivididas e várias coletas, realizadas, com determinação da média e do desvio padrão da EC em cada uma. Os transects foram pré-planejados para prover pelo menos 
100 amostras por campo. As amostragens de solos contemplaram a superficie $(2 \mathrm{~cm})$, a subsuperficie $(30 \mathrm{~cm})$ e as camada mais profundas $(30 \mathrm{a} 60 \mathrm{~cm})$. Foram determinadas também a altura de plantas e a porcentagem de área coberta (dossel).

Para os dados espectrais, foram utilizados os índices NDVI e o GVI3. Este último, foi obtido através do procedimento de Jackson (1983) para as bandas verde, vermelha e infravermelha próxima, utilizando-se três sistemas diferentes de imageamento, fotografia, videografia e imagens SPOT.

No nível da análise, os dados de campo foram utilizados para determinar como as observações se inter-relacionavam, para examinar a uniformidade e para selecionar uma profundidade de medição representativa da salinidade como um todo. Gráficos de pares de dados e matrizes de correlação foram os procedimentos utilizados para a análise de dados.

Os resultados mostraram que a salinidade, na camada de 30 $\mathrm{cm}$ do solo, teve a melhor correlação com a planta e com as observações espectrais. Das correlações entre as medições espectrais (bandas individuais e índices de vegetação NDVI e GVI3), a altura de plantas e a EC a $30 \mathrm{~cm}$, pode-se concluir que a magnitude dos coeficientes de correlação foram similares e os sinais opostos, para as duas últimas variáveis. Foi concluído também que as bandas vermelha e verde continham mais informações que a banda NIR e que diferenças na resolução, por si, não foram a principal fonte de variação (Wiegand et al., 1992). 
2.5.2.2 O ambiente de desenvolvimento Linux como base operacional para o sistema de informações geográficas Spring.

Para que se compreenda a base computacional da análise de dados deste trabalho de pesquisa, faz-se necessária uma breve explanação sobre essa base operacional e sobre o sistema de informações geográficas utilizados.

O termo Sistema de Informação Geográfica (SIG) é aplicado para sistemas que realizam o tratamento computacional de dados geográficos. Um SIG armazena a geometria e os atributos dos dados georeferenciados, isto é, localizados na superfície terrestre e numa projeção cartográfica. Os dados tratados em geoprocessamento tem como principal carcterística a diversidade de fontes geradoras e de formatos apresentados (Câmara, 1996).

$\mathrm{O}$ requisito de armazenar a geometria dos objetos geográficos e de seus atributos representa uma dualidade básica para SIGs. Para cada objeto geográfico, o SIG necessita armazenar seus atributos e as várias representações gráficas a eles associadas. Devido a sua ampla gama de aplicações, que inclui temas como agricultura, floresta, cartografia, cadastro urbano e redes concessionárias, há pelo menos três grandes maneiras de utilizar um SIG: como ferramenta para a produção de mapas, como suporte para a análise espacial de fenômenos, como um banco de dados geográficos, com funções de armazenamento e de recuperação da informação espacial (Câmara, 1996). 
O Unix é um dos mais populares sistemas operacionais veiculado pelo mundo, por causa de sua larga base de suporte e de distribuição. Ele foi originalmente desenvolvido como um sistema multitarefa para minicomputadores e mainframes, em meados da década de 70 , e é o mais popular e largamente utilizado na atualidade.

O Linux é uma versão livremente distribuída do Unix desenvolvida primariamente por Linus Torvalds, na Universidade de Helsinki, Finlândia. O Linux foi concebido como um socorro a muitos programadores Unix e encantou-os através da Internet, permitindo a qualquer pessoa com bastante conhecimento e inteligência, a habilidade de desenvolver e manipular o sistema. O "kernel"1 do Linux não usa um código da AT\&T, ou qualquer outro recurso proprietário, e muitos dos softwares disponiveis para Linux são desenvolvidos pelo projeto GNU da Free Software Foundation Cambridge, Massachusetts. Entretanto todos os programadores do mundo têm contribuído para o crescimento de softwares com base operacional em Linux (Tauber, 1995).

Nos dias de hoje, Linux é um Unix completo, capaz de inicializar Xwindows, TCP/IP, emacs, UUCP, mail, e novos softwares, entre eles o Sistema de Processamento de Imagens e Informações Geográfica SPRING -, desenvolvido pelo Instituto de Pesquisas Espaciais - INPE (INPE, 1997). Além disso, a maior parte dos softwares livres têm sido desenvolvidos para Linux. Dessa forma, seguindo a mesma premissa, o INPE disponibilizou o SPRING via rede e posssibilitou a utilização dessa poderosa ferramenta de desenvolvimento, aliás utilizada neste trabalho de pesquisa.

\footnotetext{
1o núcleo do programa, que serve como interface entre o hardware e o sistema operacional.
} 
Dentre outras possibilidades fornecidas ao usuário pelo SPRING, podem-se citar aqui: tratar dados geográficos de forma contínua, sem se procupar com fronteiras, a que ele suporta um grande volume de dados, mantendo a identidade de objetos geográficos em todo o banco; integrar dados de sensoriamento remoto, mapas temáticos e cadastrais e modelos numéricos de terreno; administrar diversas formas de representação de dados, tanto matriciais como vetoriais; operar nos mais diversos ambientes computacionais.

Dentre o grande número de funções disponíveis no SPRING, destacam-se: álgebra de mapas em LEGAL-, consultas por atributos e por restrições espaciais, geração de grade (regular e triangular), mapas de declividade e exposição, visualização 3D, manipulação de histograma, filtragem, transformação IHS e de componentes principais, restauração, tratamento de imagens de radar, segmentação, classificação por pixel e por região.

O Linux é um sistema operacional de 32 bits destinado para uso em microcomputadores PCs. Tecnicamente, o Linux é um sistema operacional Unix, o que significa que ele responde a qualquer comando padrão Unix, assim como programas executáveis.

O SPRING está disponível para o ambiente Linux, e testado apenas para versões que incluem o Slackware 96. Por ser um sistema operacional freeware, assim como o SPRING, muitos usuários têm optado por utilizar, em seus micros, Linux+Spring, como opção mais acessível à tecnologia de geoprocessamento. Para este trabalho, foi utilizada a versão 2.0.4 do SPRING (INPE, 1997) em conjunto com a versão completa Slackware 96 do sistema operacional Linux. 


\section{MATERIAIS E MÉTODOS}

O trabalho de laboratório em sensoriamento remoto foi dividido em três fases. Na primeira, realizou-se a inserção dos dados através de digitalização de mapas, na escala 1:500.000 (BAHIA, 1986), para a caracterização fluviomorfológica e agroclimática da bacia do rio Salitre, para a formação dos Planos de Informações (PIs) e para a definição do esquema conceitual. Na segunda etapa, foram realizados os cruzamentos entre planos de informações através da LEGAL, e as variáveis ambientais, contidas nos diferentes PIs, e necessárias às definições contidas no modelo conceitual de produção de cultivos, sob condições de salinidade. E, por fim, realizaram-se os estudos em sensoriamento remoto, necessários ao processo de quantificação das condições atual e futura, para regiões específicas da Bacia.

\subsection{Definindo o esquema conceitual}

Num SIG existem duas formas de organização de um ambiente de trabalho: organização baseada num banco de dados geográficos e organização baseada em projetos. No primeiro caso, o usuário define, inicialmente, o esquema conceitual associado às entidades do banco de dados geográficos, indicando cada tipo de dado para seus atributos não-espaciais e as representações geométricas a eles associadas. Procede-se da mesma forma 
que num banco de dados tradicional, onde a estrutura do banco precede a entrada dos dados. O SPRING é um exemplo de sistema organizado como banco de dados geográficos.

No segundo caso, o usuário define, inicialmente, um referencial geográfico (que delimita uma região de trabalho) e, a seguir, as entidades geográficas que compõem o projeto. Note-se que um banco de dados geográficos pode ser particionado em projetos, e que as definições do esquema conceitual valem para todos os projetos do banco, mesmo que não haja continuidade espacial entre eles.

Um projeto é usualmente composto por um conjunto de níveis, camadas ou planos de informação (PIs), que variam em número, tipos de formatos e de temas, conforme as necessidades de cada tarefa ou estudo. Por exemplo, caso se desejasse fazer um estudo de uso atual do solo e de seus impactos sobre o ambiente de uma região, definida em um projeto, seria necessário que tal projeto fosse composto de PIs com os seguintes temas: rede de drenagem, cidades, rodovias e ferrovias, altimetria, geomorfologia, unidades e associações de solos, tipologia vegetal, tipos de uso e ocupação das terras. Alguns PIs, quando superpostos, vão caracterizar a região de estudo, ou mapa topográfico, de acordo com um modelo, ou não. Os PIs restantes são os mapas espaciais ou temáticos, necessários para atingir o objetivo proposto, isto é, cada PI representa uma mesma área com informações diferentes.

Tal organização da informação espacial é muito conveniente para permitir que diferentes variáveis sejam integradas ao banco de dados e que diferentes tipos de estudo possam ser realizados, combinando tão somente os fenômenos de interesse. Desse modo, pode-se dizer que o 
Geoprocessamento, ao organizar no computador os dados geográficos, modifica qualitativamente o tipo de análise possível (Câmara, 1996).

3.1.1. Inserção dos dados de caracterização fisiográfica da bacia do rio Salitre em planos de informação.

Uma caracterização preliminar da bacia hidrográfica do rio Salitre é a exiguidade de reservas hídricas, aliada a fatores climáticos adversos, que acarretam sérios problemas de desgaste na economia hídrica regional, promovendo a paulatina degradação dos reduzidos recursos.

A análise das características climáticas e fluviomorfológicas da bacia assume importância fundamental no estudo das potencialidade dos recursos naturais. A potencialidade hídrica, representada pelas vazões em trânsito nos cursos d'água, depende essencialmente do clima e das características fisicas da bacia contribuinte. Torna-se fácil, portanto, compreender a ênfase atribuída a esses dois fatores, como preliminar de qualquer estudo hidrológico.

A representação das características fluviomorfológicas de uma bacia, através de parâmetros definidores, não só facilita a síntese dos seus aspectos dominantes, como também possibilita as comparações entre diferentes bacias, permitindo a transferência de dados mais completos, ou mais confiáveis, em regiões fisiograficamente semelhantes.

A bacia do rio Salitre faz parte da bacia do rio São Francisco e encontra-se localizada entre as latitudes $9^{\circ} 27^{\prime}$ e $11^{\circ} 30^{\prime}$ Sul e entre as longitudes $40^{\circ} 22^{\prime}$ e $41^{\circ} 30^{\prime}$ Oeste, limitada pelas bacias dos rios Tourão e 
Jacaré. O seu curso d'água principal - o rio Salitre - nasce na Chapada Diamantina, no município de Morro do Chapéu, e deságua no rio São Francisco, à $20 \mathrm{~km}$ à montante da cidade de Juazeiro.

A área da bacia, delimitada em documento cartográficos, na escala 1:500.000 foi avaliada em $14.510 \mathrm{~km}^{2}$; a topografia muito plana e a ausência de rede hidrográfica no seu trecho inferior podem prejudicar a precisão desta estimativa (SEPLANTEC, 1986).

3.1.1.1 O plano de informação geologia.

Predominam, na bacia, as rochas do Pré Cambriano superior, representadas pelos grupos Bambuí e Chapada Diamantina. As rochas sedimentares antigas ocorrem em todo o médio e alto vale, sendo constituídas de arenitos, folhelhos, siltes, argilitos e calcários. Identifica-se ao longo de toda a bacia a presença de rochas calcárias mais recentes (Terciário e Quaternário), recobrindo indiscriminadamente as rochas do complexo précambriano. A Figura 5 mostra as principais classes de ocorrências minerais, reproduzidas a partir do módulo SCARTA do SPRING .

As rochas mais antigas do complexo cristalino somente afloram na porção inferior da bacia. Os depósitos aluvionares ocorrem ao longo de quase todo o vale, em uma estreita faixa de pouca espessura, estendendo-se às proximidades da foz e chegando a confundir-se com os colúvios que descem das encostas dos vales (BAHIA, 1986). 


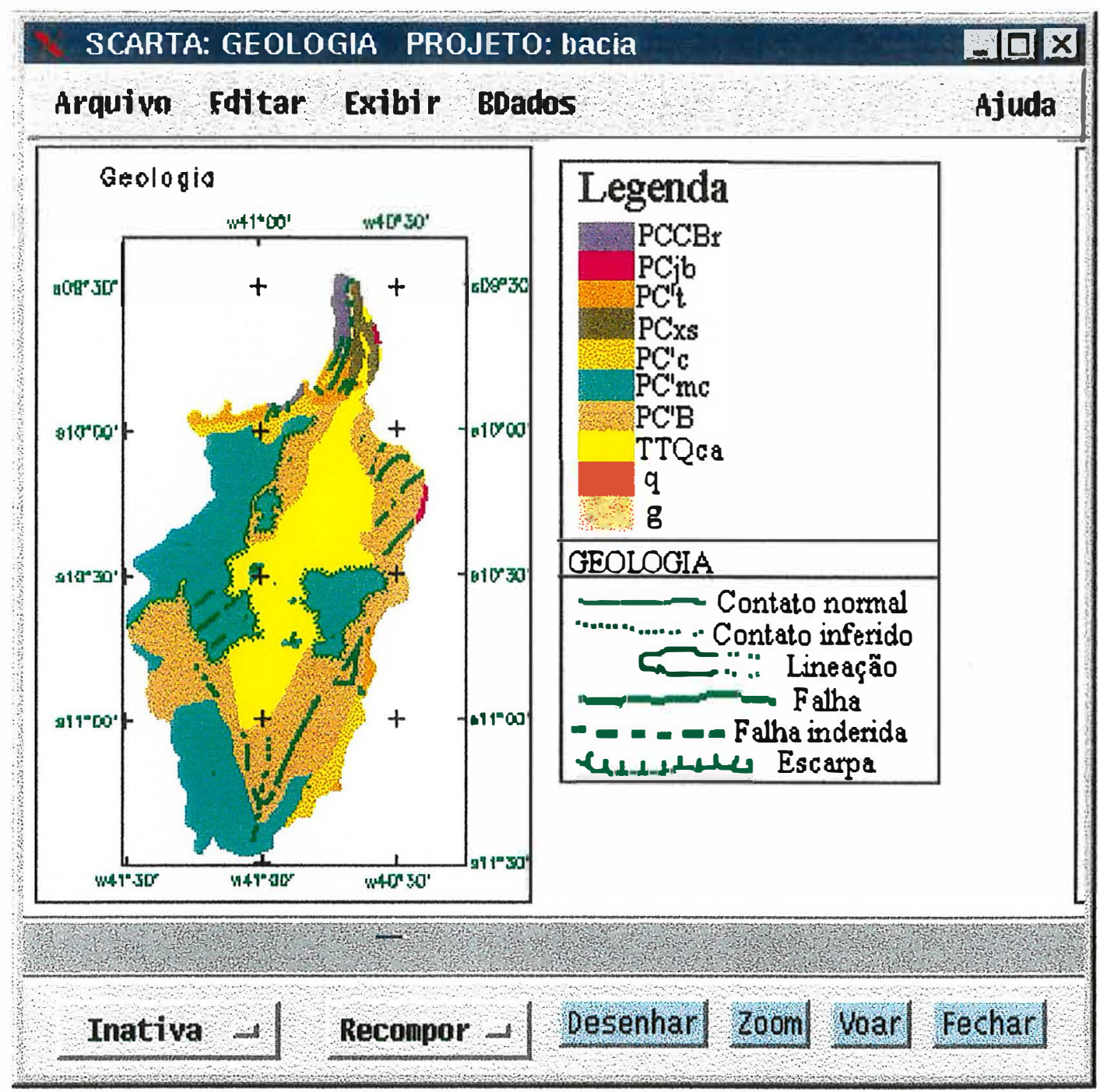

Figura 5 - Principais classes de ocorrências minerais da Bacia do Rio Salitre visualizadas através do modo SCARTA do SPRING versão 2.0.4.

As rochas calcárias, recentes, do interior do continente, situadas na região sanfranciscana, são englobadas sob o nome de Formação Caatinga. São descritas como margas contendo areias e matacões, depositadas sobre rochas cristalinas, ou sobre calcários pré-cambrianos. São depósitos de reduzida espessura, que contêm restos de animais pertencentes a gêneros ainda vivos, principalmente gastrópodes. Esses depósitos são de origem 
fluvial, favorecidos pelas condições climáticas locais. As águas que fluem sobre os calcários pré-cambrianos conduzem carbonato de cálcio dissolvido. Nos períodos de cheia, grandes áreas são inundadas e, no período de águas baixas, o lento recuo das águas de inundação permite que elas sejam aquecidas pelo calor do sol. $\mathrm{O}$ dióxido de carbono é, então, parcialmente liberado e o óxido de cálcio é depositado no fundo, sobre os sedimentos terrígenos, normais do ambiente fluvial. A repetição do processo, que se supõe iniciado no Pioceno, produziu a mistura de terrígenos com a massa calcífera, observável na região de Juazeiro.

O grupo Chapada Diamantina apresenta rochas de idade précambriana, representadas por Metaarenitos, Metaconglomerados, Metassiltitos e Metargilitos. Possuem boa seleção granulométrica, são bem estratificados e de colorações variando entre os tons de rosa e branco. É subdividido em três formações, assim descritas, da base para o topo, Formação Tombador, Formação Cabloco e Formação Morro do Chapéu.

A Formação Tombador constitui-se de arenitos róseos, formando-se bancos à medida que as rochas mostram maiores sinais de cataclase. A granulação varia de fina a grosseira, enquanto estratificações cruzadas de médio porte são freqüentes. Níveis de arenito conglomerático e conglomerados finos podem ser reconhecidos. Podem também ser silificados e fraturados, adquirindo uma coloração branca.

A Formação Cabloco apresenta coberturas de solos bem desenvolvidas, que podem prejudicar a sua caracterização. Os afloramentos descritos registram a presença de siltitos e argilitos, com diferentes graus de silificação, além de calcários. 
A Formação Morro do Chapéu é aquela do grupo Chapada Diamantina mais bem representada na bacia do Rio Salitre. Litologicamente constituí-se de um nível conglomerático basal, seguido de bancos de metarenitos róseos, médios a finos, culminando com metarenitos brancos com intercalações argilosas. Sua espessura é estimada em 390 metros.

Os grupos Jacobina, Cabrobó e Xisto Salitre ocorrem pouco na área. Aparecem como afloramentos de pequena extensão na porção norte da bacia, e em uma pequena faixa da borda leste. São representados por metaclásticos diversos, xistos verdes e lentes de quartizitos associados, correspondendo ao grupo Jacobina. Gnaiss, leptinitos, xistos e quartizitos representam o grupo Cabrobó. Micaxistos e filitos representam o Salitre.

O gnupo Bambuí, cujas rochas repousam discordantemente sobre o grupo Chapada Diamantina ou mesmo sobre rochas mais antigas, é subdividido em duas formações distintas a saber: a Formação Bebedouro e a Formação Salitre.

A Formação Bebedouro caracteriza-se pela presença de Metassedimentos siltico-argilosos, aos quais se associam lentes contínuas de metagrauvacas conglomeráticas, com seixos de formas angulares, tamanhos variáveis, esparsamente distribuídos na matriz síltico-argilosa. Sua espessura é variável, podendo chegar até os 70 metros. Sua ocorrência típica centra-se na localidade de Laje do Batata. É considerada por muitos autores como uma formação de origem glacial.

A Formação Salitre, denominação proveniente da designação dada ao rio, é constitui-se por uma seqüência de calcários cinza, microcristalinos, bem estratificados, com níveis dolomíticos e intercalações de ardósias. 
A Tabela 1 mostra uma coluna estatigráfica, com o período, a unidade litoestatigráfica, em relação a cada símbolo da legenda da Figura 5, e a litologia da $\bar{B}$ acia Hidrográfica do Rio Salitre.

Tabela 1 - Coluna estatigráfica com o período geológico, unidade litoestatigráfica, o símbolo da unidade de mapeamento na Figura $\overline{5}$, e a litologia da Bacia Hidrográfica do Rio Salitre.

\begin{tabular}{|c|c|c|c|}
\hline PQPEOTHO & 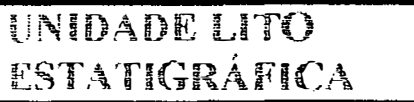 & 3月R日P & DT \\
\hline $\begin{array}{l}\text { QUATERNÁRIO E } \\
\text { TERCIÁRIO }\end{array}$ & Calcário Caatinga & TTQca & $\begin{array}{l}\text { Calcário branco, } \\
\text { maciço } \\
\text { pulverulento }\end{array}$ \\
\hline \multirow[t]{4}{*}{$\begin{array}{l}\text { PRE-CAMBRIANO } \\
\text { SUPERIOR }\end{array}$} & $\begin{array}{l}\text { Grupo Bambuí } \\
\text { Grupo Chapada } \\
\text { Diamantina } \\
\text { - Formação MORRO }\end{array}$ & $\mathrm{PC}^{\prime} \mathrm{B}$ & $\begin{array}{l}\text { Calcários, } \\
\text { dolomitos, } \\
\text { ardósias. }\end{array}$ \\
\hline & DO CHAPÉU & PC'mc & $\begin{array}{l}\text { Arenitos } \\
\text { ortoquartizitos } \\
\text { claros e bem } \\
\text { estratificados }\end{array}$ \\
\hline & 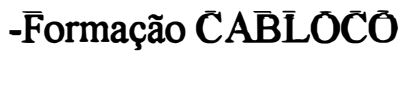 & $\overline{\mathrm{P}} \bar{C}^{\prime} \mathrm{c}$ & $\begin{array}{l}\text { Folhelhos, argilas, } \\
\text { siltitos }\end{array}$ \\
\hline & 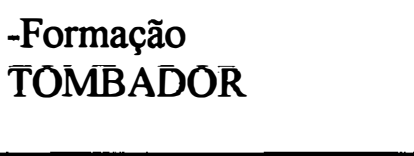 & $P C^{\prime} t$ & $\begin{array}{l}\text { Arenitos } \\
\text { grosseiros, mal } \\
\text { estratificados. }\end{array}$ \\
\hline \multirow[t]{2}{*}{$\begin{array}{l}\text { PRÉ-CAMBRIANO } \\
\text { MÉDIO E INFERIOR }\end{array}$} & $\begin{array}{l}\text { Xisto SALITRE } \\
\text { Grupo CABROBÓ }\end{array}$ & $\begin{array}{l}\text { PCxs } \\
\text { PCCbr }\end{array}$ & $\begin{array}{l}\text { Micaxistos, filitos. } \\
\text { Gnaisses, } \\
\text { leptinitos, xistos e } \\
\text { quartizitos }\end{array}$ \\
\hline & Grupo JAC $\overline{\mathrm{C}} \overline{\mathrm{B}} \overline{\mathrm{IN}} \mathrm{A}$ & $\overline{\mathrm{P}} \mathrm{C} \mathrm{jb}$ & $\begin{array}{l}\text { Metaclasticos, } \\
\text { gnaisses, xistos } \\
\text { verdes e lentes } \\
\text { quartizíticas }\end{array}$ \\
\hline \multirow[t]{2}{*}{ INDIFERENCIADO } & & $\mathrm{q}$ & Quartizitos \\
\hline & & g & Granitos \\
\hline
\end{tabular}


A Formação Caatinga repousa discordantemente sobre os calcários Bambuí, ou sobre rochas do próprio embasamento cristalino. Tratase de um calcário branco, de textura fragmentária, maciço e muito compacto, de aspecto pulverulento, quando alterado, explorado como mármore comercial em muitos locais. É considerado de idade bem recente, Quaternário e Terciário.

\subsubsection{O plano de informação solos.}

A Figura 6 mostra uma visão geral das potencialidades dos recursos de solos da área. com suas principais classes de solos reproduzidas a partir do módulo SCARTA do SPRING, após digitalização.

Foram mapeadas as seguintes unidades: Cambissolo, Latossolo Vermelho Amarelo, Litólico, Planossolo, Bruno-Não-Cálcico, Podzólico Vermelho Amarelo, Areia Quartzosa, Regossolo, Vertissolo e vestígios de Solonetz associado ao Planossolo.

O Cambissolo constitui a unidade de mapeamento predominante, com $40,34 \%$ da área total da bacia; encontra-se distribuído de norte a sul da bacia, concentrando-se principalmente na parte oriental do submédio Salitre e corresponde geralmente a áreas de substrato calcário.Tais solos são muito porosos, bem drenados, de textura franco-argilosa, rasos a moderadamente profundos, praticamente neutros a fortemente alcalinos. 


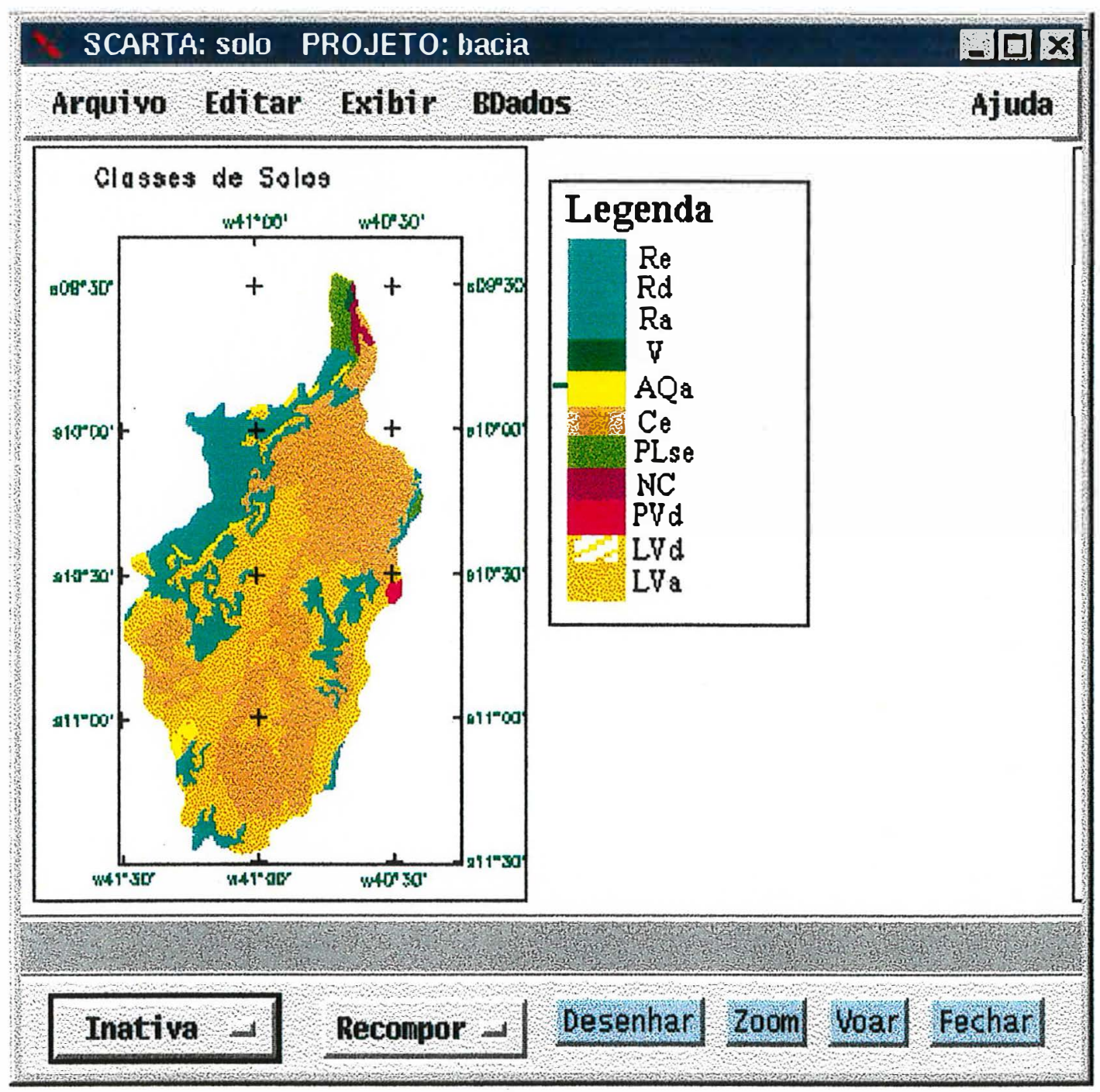

Figura 6 - Mapa das classes de solos da bacia hidrográfica do rio Salitre visualizadas através do módulo SCARTA do SPRING.

Consideram-se esses como os melhores solos da bacia, para o desenvolvimento da agricultura, com excelente permeabilidade e aeração. Possuem boa reserva mineralógica, permitindo regular produção por longo tempo. São utilizados para pecuária extensiva de caprinos/ovinos na caatinga, como também para culturas irrigadas e de sequeiro, nas áreas mais propícias para o cultivo. 
O Latossolo Vermelho Amarelo ocupa uma superficie equivalente ao Cambissolo, com $31,83 \%$ da área total da bacia. Ocorre no médio e alto curso da bacia, mais acentuadamente na parte ocidental. Esse solo encontra-se disseminado em relevo suave e ondulado e nos topos planos de pendentes longas e deriva-se de Metassedimentos do grupo Chapada Diamantina, sobressaindo-se as formações Morro do Chapéu, Tombador e Cabloco.

Caracterizam-se pelo avançado grau de intemperização de arenitos grosseiros, mal estratificados. Apresentam como maior limitação ao uso agrícola, a baixa fertilidade natural, embora sejam fisicamente bons, de manejo fácil, praticamente sem problemas de erosão, podendo ser trabalhados com diversos tipos de máquinas agrícolas, devido ao relevo favorável. Apresentam-se pouco cultivados, conservando quase intacta a vegetação natural.

Os solos Litólicos, com $22,39 \%$ da área total da bacia, ocorrem em áreas dissecadas, com relevo variando de suave ondulado a fortemente ondulado, estando a maior concentração localizada a noroeste da bacia, evidenciando-se outras ocorrências, em elevações situadas a leste da bacia, entre Riachão e o vereda da Caatinga do Moura e pequenos manchas em trechos dissecados a nordeste e sudeste da bacia. São solos pouco desenvolvidos, rasos ou muito rasos, apresentando bastante pedregosidade e rochosidade na superficie, que condicionam a pequena profundidade do solo, que restringe a sua utilização agrícola. $O$ uso principal é a pecuária extensiva e pequenas culturas de subsistência.

Os Planossolos, com 1,92\% da área total, situam-se nas proximidades da foz, à margem esquerda do rio Salitre. Tais solos, geralmente 
pouco profundos, imperfeitamente drenados, devido à topografia, possuem baixa permeabilidade e são bastante susceptíveis à erosão. Apresentam-se moderadamente ácidos a praticamente neutros, com solução e saturação de bases altas.

Os solos Bruno-Não-Cálcicos detêm $0,65 \%$ da área total e situam-se à margem direita do rio Salitre, próximo a sua foz. São pouco profundos a rasos, moderadamente ácidos, de alta fertilidade natural, imperfeitamente drenados e bastante susceptíveis à erosão. Quanto ao uso atual, observam-se a pecuária extensiva, na área da caatinga, e culturas irrigadas, nas proximidades do rio Salitre.

As demais unidades mapeadas, isto é, Podzólico Vermelho Amarelo, Areias Quartzosas, Regossolo, Vertissolo e Solonetz, que na sua totalidade representam $0,85 \%$ da área da bacia, ocorrem em áreas restritas $\mathrm{e}$ apresentam baixa fertilidade e susceptibilidade a erosão, exceção feita aos Vertissolos e Solonetz.

Cabe salientar que o método de obtenção das porcentagens em área de cada unidade de mapeamento, é realizado através do SPRING, de forma automática.

\subsubsection{O plano de informação vegetação.}

A bacia do rio Salitre apresenta-se constituída das seguintes formações vegetais: Caatinga, Cerrado e Vegetações Secundárias. A Figura 7 mostra as principais formações vegetais, reproduzidas a partir do módulo SCARTA do SPRING . 


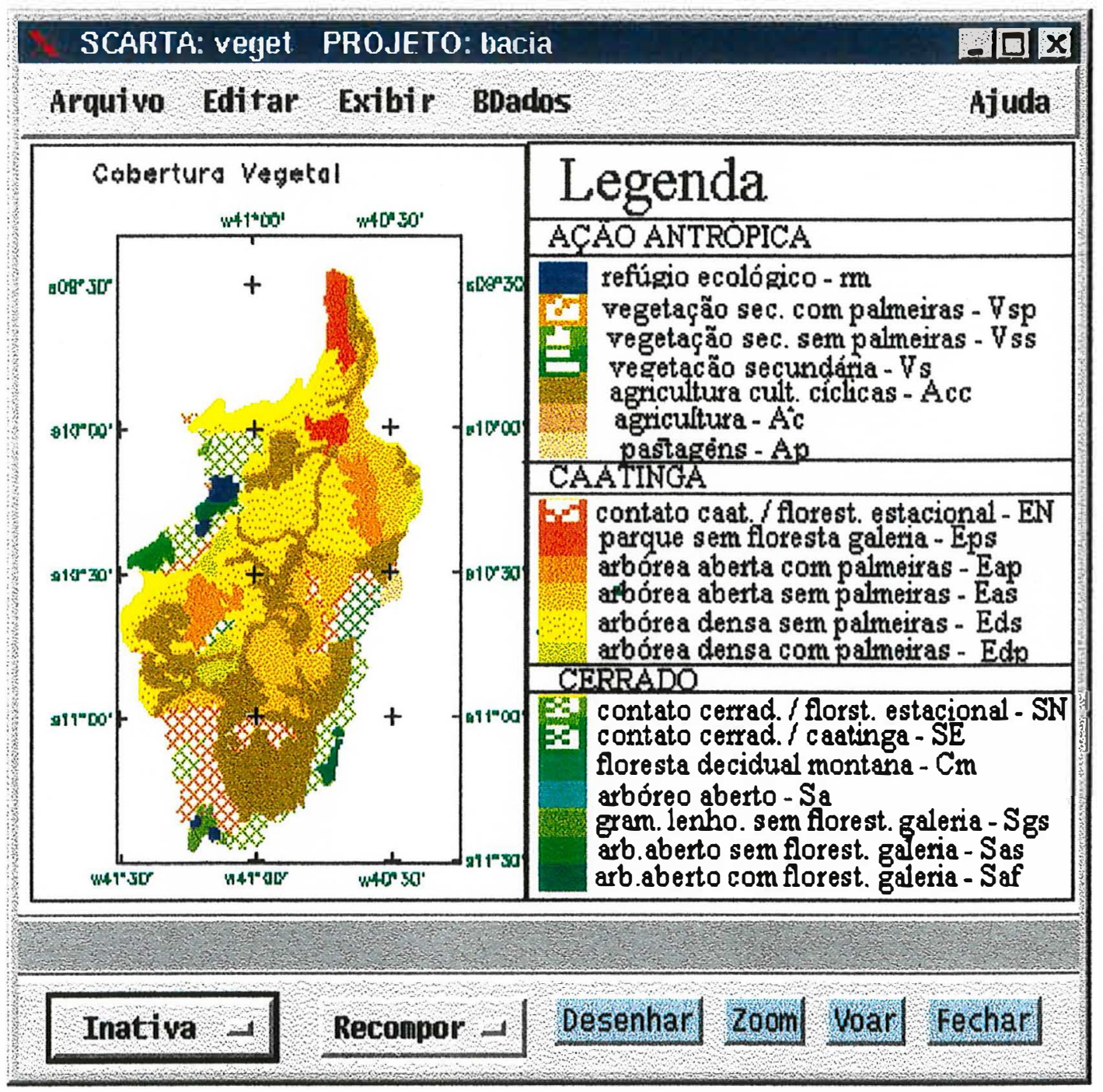

Figura 7 - Reprodução do plano de informação Formações Vegetais através do módulo SCARTA do SPRING.

A Caatinga é a vegetação dominante, compreendendo $8.567,76 \mathrm{~km}^{2}$ de área, que correspondem a 59,16\% da área total, distribuída uniformemente por toda a bacia. Evidenciam-se as formas biológicas de: umbuzeiro, quixabeira, aroeira, marmeleiro, jurema, variedades de cactáceas como xique-xique, mandacaru, facheiro, coroa de frade e capins do tipo 
panasco, burro e carrapicho de boi. Constata-se a presença de duas subformações: Caatinga Arbórea Densa e Arbórea Aberta.

A Caatinga Arbórea Densa, ocorre nas baixadas do rio Salitre, recobrindo os terrenos do Quaternário e do Terciário, caracterizados por Cambissolos Eutróficos e Latossolos Vermelho Amarelo. Registra-se a ocorrência de caatinga arbórea densa com palmeira, em alguns locais à margem esquerda do rio Salitre, a montante da localidade Pedra Vermelha, a noroeste de Delfino (município de Campo Formoso), e individualizando-se pela distribuição expressiva das palmeiras ouricuris e licuriboia.

A Caatinga Arbórea Aberta encontra-se vinculada ao Cambissolo Eutrófico, utilizado grandemente com a finalidade agrícola, restando poucos agrupamentos remanescentes da cobertura original. Os testemunhos concentram-se a leste da bacia.

O Cerrado ocorre a noroeste, sul e sudeste da bacia, correspondendo a uma área de $2.274,79 \mathrm{~km}^{2}$, que correspondem a $15,71 \%$ da área total da bacia, nas áreas areníticas-quartzíticas do Planalto Diamantino, principalmente onde se evidencia uma cobertura de Latossolo Vermelho Amarelo Álico e Distrófico e de solos Litólicos de textura arenosa. O Cerrado encontrado na área, é do tipo Arbóreo Aberto, apresentando dois sub-tipos: Arbóreo Aberto sem Floresta de Galeria e Arbóreo Aberto com Floresta de Galeria.

O Cerrado Arbóreo aberto com Floresta de Galeria surge nos prolongamentos a nordeste da Chapada de Morro do Chapéu, ladeando a parte frontal da Serra do Tombador, ocorrendo também nas áreas de encraves próximas a Campo Formoso. Essa formação vegetal assenta-se sobre o Latossolo Vermelho Amarelo e Litólicos, ambos associados a Areias 
Quartzosas. Nas áreas de influência de pequenos córregos que drenam a área, há um acréscimo na densidade e na estrutura dos indivíduos, bem como na florística, aparecendo a contribuição de espécies caracteristicamente florestais.

O Cerrado Arbóreo Aberto sem Floresta de Galerias, ocorre entre as serras da Caiçara, do Alegre, de Angelim e da Gameleira, a oeste de Delfino (município de Campo Formoso), nos Blocos Planálticos Setentrionais, com terrenos do Pré-Cambriano, e preponderando os solos Litólicos distróficos, textura arenosa, sobre o Latossolo Vermelho Amarelo distrófico.

Registra-se a presença de Vegetação Secundária com Palmeira, nas áreas de serras mais úmidas, com altitudes variando de $700 \mathrm{a}$ $800 \mathrm{~m}$, ressaltando-se a palmeira babaçu, e de Floresta Estacional Semidecidual ou Decidual, identificadas nas áreas mais conservadas do Planalto Diamantino, na Chapada de Morro do Chapéu.

O Refúgio Ecológico, compreende a formação vegetal que constitui uma comunidade herbáceo-graminosa, associada a pequenos arbustos lenhosos, dispersos sobre solos Litólicos Álicos e Quartzosos, encontrado na serra da Jacobina e na Chapada de Morro do Chapéu.

As áreas cultivadas, mais o refúgio ecológico, compreendiam, em 1987, 25,13\% da área total da bacia, concentrando-se nos trechos de solos derivados da alteração dos calcários, ao longo dos principais cursos d'água (BAHIA, 1986).

Cabe salientar que os dados de cobertura vegetal foram digitalizados a partir de mapas na escala de 1:500.000 da bacia, no intuito de formar o banco de dados georreferenciados; as porcentagem, na área de cada 
formação vegetal, foram determinadas, de forma automática através do SPRING.

3.1.1.4. O plano de informação densidade de drenagem.

A análise das características climáticas e fluvio-morfológicas da bacia assume importância fundamental no estudo das potencialidades dos recursos naturais.

A potencialidade hídrica, representada pelas vazões em trânsito nos cursos d'água, depende essencialmente do clima e das características fisicas da bacia contribuinte. Torna-se fácil, portanto, compreender a ênfase atribuída a esses dois fatores como preliminar de qualquer estudo hidrológico.

Funciona a bacia de drenagem como coletor de águas pluviais, recolhendo-as e conduzindo-as, como escoamento, ao exutório. É assim que o relevo, a forma, a rede de drenagem, a declividade, a cobertura vegetal e a natureza do solo da bacia condicionam, no espaço e no tempo, a relação precipitação-vazão nos rios.

A representação das características flúvio-morfológicas de uma bacia, através de parâmetros definidores, não só facilita a síntese dos seus aspectos dominantes, como também possibilita as comparações entre diferentes bacias, permitindo a transferência de dados mais completos, ou mais confiáveis, em regiões fisiograficamente semelhantes.

Assim foram estabelecidos alguns parâmetros flúviomorfológicos que definissem a bacia e as sub-bacias de contribuição. Tais 
parâmetros foram determinados utilizando-se os dados cartográficos, obtidos automaticamente através do SPRING.

O comprimento do curso d'água principal, expresso pelo comprimento do rio Salitre, medido desde suas cabeceiras, na Chapada Diamantina, no município de Morro do Chapéu, até a sua foz, na confluência com o rio São Francisco, perfaz um total de $270 \mathrm{~km}$.

A partir dos dados de área da bacia e comprimento do curso d'água principal foi definido a fator de forma da bacia (Villela \& Mattos, 1975), expresso pelo quociente entre a área da bacia e o quadro do comprimento do curso d'água principal.

$$
\mathbf{F}=\frac{\mathbf{A}}{\mathbf{L}^{2}}
$$

onde F é o fator de forma; $\mathbf{A}$, a área total da bacia determinada pelos divisores de água em $\mathrm{km}^{2}$; e $\mathbf{L}$, o comprimento do curso d'água principal em $\mathrm{km}$. O valor de F definido para a bacia do rio Salitre foi de 0,2.

O coeficiente de compacidade é expresso pela relação entre o perímetro da bacia e o perímetro de um círculo com a mesma área, expresso pela relação

$$
K c=\frac{P}{2 \sqrt{\pi \cdot A}}
$$

onde Kc é o coeficiente de compacidade; $\mathbf{P}$, o perímetro da bacia em $\mathrm{km}$ e $\mathbf{A}$, a área da bacia em $\mathrm{km}^{2}$. Para a bacia do rio Salitre, cujo perímetro é de 640 $\mathrm{km}$, o coeficiente de compacidade tem valor de 1,5.

A forma da bacia tem grande importância no escoamento e, portanto, no comportamento da bacia aos estímulos de chuva: sendo estreita e alongada, o seu tempo de concentração é maior e mais dificilmente se terá a 
ocorrência de uma chuva simultânea sobre toda a bacia; de maneira inversa ocorrerá, se a bacia for compacta e arredondada.

No caso da bacia do rio Salitre, os valores dos coeficientes encontrados definem a bacia como ligeiramente alongada, relativamente compacta e regular. Vale dizer que, sem levar em conta outro fatores, estará sujeita a cheias intensas, porém de curta duração.

Outro elemento de auxílio para a comparação entre bacias, introduzido por hidrologistas franceses é o retângulo equivalente. Esse elemento foi definido com o intuito de comparar a influência das características da bacia sobre o escoamento. Considerando-se homogêneas as condições climáticas e de cobertura vegetal, supõe-se que o escoamento de uma bacia seja igual ao de um retângulo de mesma área, de mesmo coeficiente de compacidade e de análoga repartição hipsométrica.

Sendo $\mathbf{P}$ o perímetro da bacia $\mathrm{em} \mathrm{km}, \mathbf{A}$ a área da bacia em $\mathrm{km}^{2}$, Kc o coeficiente de compacidade, $\mathbf{L}$ o lado maior do retângulo equivalente em $\mathrm{km}$ e b o lado menor do retângulo equivalente em $\mathrm{km}$, chegase às seguintes relações (Villela \& Mattos, 1975):

$$
L=\frac{K c \cdot \sqrt{A}}{1,12}\left[1+\sqrt{1-\left(\frac{1,12}{K c}\right)^{2}}\right]
$$

e para o lado menor do retângulo equivalente tem-se

$$
b=\frac{K c \cdot \sqrt{A}}{1,12}\left[1-\sqrt{1-\left(\frac{1,12}{K c}\right)^{2}}\right]
$$

Portanto o retângulo equivalente da bacia do rio Salitre tem $265,31 \mathrm{~km}$ de comprimento por $54,69 \mathrm{~km}$ de largura. 
A rede hidrográfica da bacia é formada pelo rio Salitre (rio principal) e pelos seus afluentes principais da margem direita: o Riacho Conceição, Riacho Baixa do Sangrador, Vereda Caatinga do Moura, Riacho Riachão, Riacho das Piabas. Na margem esquerda são o Riacho do Orlando, Riacho do Marim, Rio Preto, Rio Pacuí e o Riacho Escurial.

Todos os rios e riachos das sub-bacias da bacia do rio Salitre foram identificados por uma cor de acordo com a classificação de Strahler para o sistema de ordenamento de canais, conforme Tucci (1993). Outros rios menores, ou cuja denominação não foi possível identificar, foram agrupados segundo a sua localização em sub-bacias, denominadas de acordo com a sua ordem.

Os atributos armazenados no banco de dados georreferenciados, utilizando-se o SPRING, foram o nome da sub-bacia, a área $\mathrm{em} \mathrm{km}^{2}$, o comprimento do rio principal da sub-bacia em $\mathbf{k m}$, o fator de forma calculado, o coeficiente de compacidade, a altitude máxima em $\mathrm{m}$, a altitude mínima em $\mathrm{m}$, a altitude média em $\mathrm{m}$, o retângulo equivalente comprimento $\mathbf{L}$ em $\mathrm{km}$ e largura $\mathbf{b} \mathrm{em} \mathrm{km}$, o índice de declividade global, o desnível específico e a extensão superficial média em $\mathrm{km}$.

Uma boa noção da drenagem de uma bacia obtém-se pela relação entre a extensão total dos cursos d'água e a área da bacia. A esse parâmetro, denominamos densidade de drenagem

$$
\operatorname{Dd}=\frac{\sum \mathbf{L}}{\mathbf{A}}
$$

onde Dd é a densidade de drenagem; $\Sigma \mathbf{L}$, o somatório de todos os cursos d'água em m que compõem a bacia e $\mathbf{A}$, a área total da bacia estabelecida pelos divisores de águas em $\mathrm{km}^{2}$. Para a bacia do rio Salitre foi encontrada 
uma densidade de drenagem de $137,4 \mathrm{~m} / \mathrm{km}^{2}$. Tal resultado mostra que a bacia do rio Salitre dispõe de uma rede de drenagem pouco densa.

O procedimento utilizado para a obtenção dos valores de densidade de drenagem, para toda a bacia, foi a adoção da célula com traçado de 4 linhas transversais e 4 linhas verticais, efetuando-se a contagem dos pontos de interseção, conforme se verifica na Figura 8. Para evitar superposição da contagem de pontos optou-se por incluir no âmbito da célula a linha limítrofe vertical esquerda e a horizontal inferior, excluindo a vertical da direita e a horizontal superior, que são incluídas na célula vizinha.

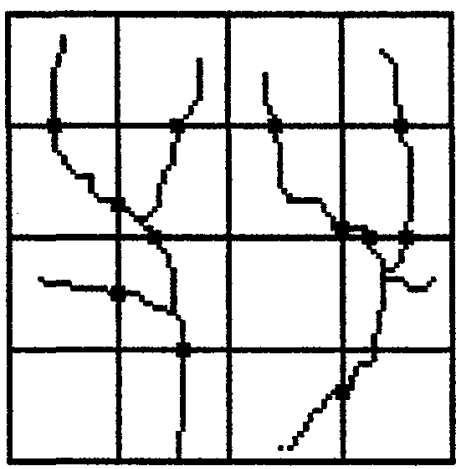

Figura 8 - Exemplo de malha de interseção de pontos com a rede de drenagem para determinação da Densidade de Drenagem.

O valor da Densidade de Drenagem foi calculado usando-se o quociente de número de interseções (No) pelo comprimento das linhas (Lo), multiplicado por uma constante, de modo que Dd é igual a 1,83 da razão No/Lo; utilizaram-se mapas na escala de 1:100.000 (BAHIA, 1986).

A densidade de drenagem é representativa da extensão dos canais de escoamento por unidade de área. Indica a quantidade e a 
disponibilidade de canais, para o escoamento do fluxo de água, e de materiais detríticos.

A distribuição dos valores da densidade de drenagem expressa a ordem qualitativa e não quantitativa de expressão absoluta e real. Consideram-se, portanto, as diversas classes em função do escalonamento, tomando-se o critério de valorização da ordem de baixa para alta densidade, uma vez que, quantitativamente, a densidade de drenagem total da bacia pode ser considerada baixa.

As classes estabelecidas foram dispostas na Legenda da Figura 9. O mapa de densidade de drenagem foi digitalizado a partir de carta na escala de 1:500.000 (BAHIA, 1986) utilizando-se o SPRING.

As classes de densidade de drenagem estabelecidas foram agrupadas em baixa e alta densidade cujas características são descritas a seguir.

Verifica-se que $71,2 \%$ da área se encontram-se nas classes $4 \mathrm{e}$ 5 , sendo que a classe 5 representa $24,08 \%$ e a classe 4 representa, $47,12 \%$. A classe 3 ocupa $25,11 \%$ da área, as classes 2 e 1 representam 2,92\% e 0,75\%, respectivamente.

Os rios são intermitentes cursos d'água, de regime cortado, permanecendo escoamento da calha durante algum tempo após a cessação das chuvas;são abastecidos pelos lençóis aqüíferos que, de início, alimentadores (rios afluentes) passam a alimentados (rios influentes), até que os lençóis abastecidos anulem a vazão de calha. Por ocasião da ausência do escoamento de calha, surge, em largo espaço de tempo, o escoamento subaveolar. 


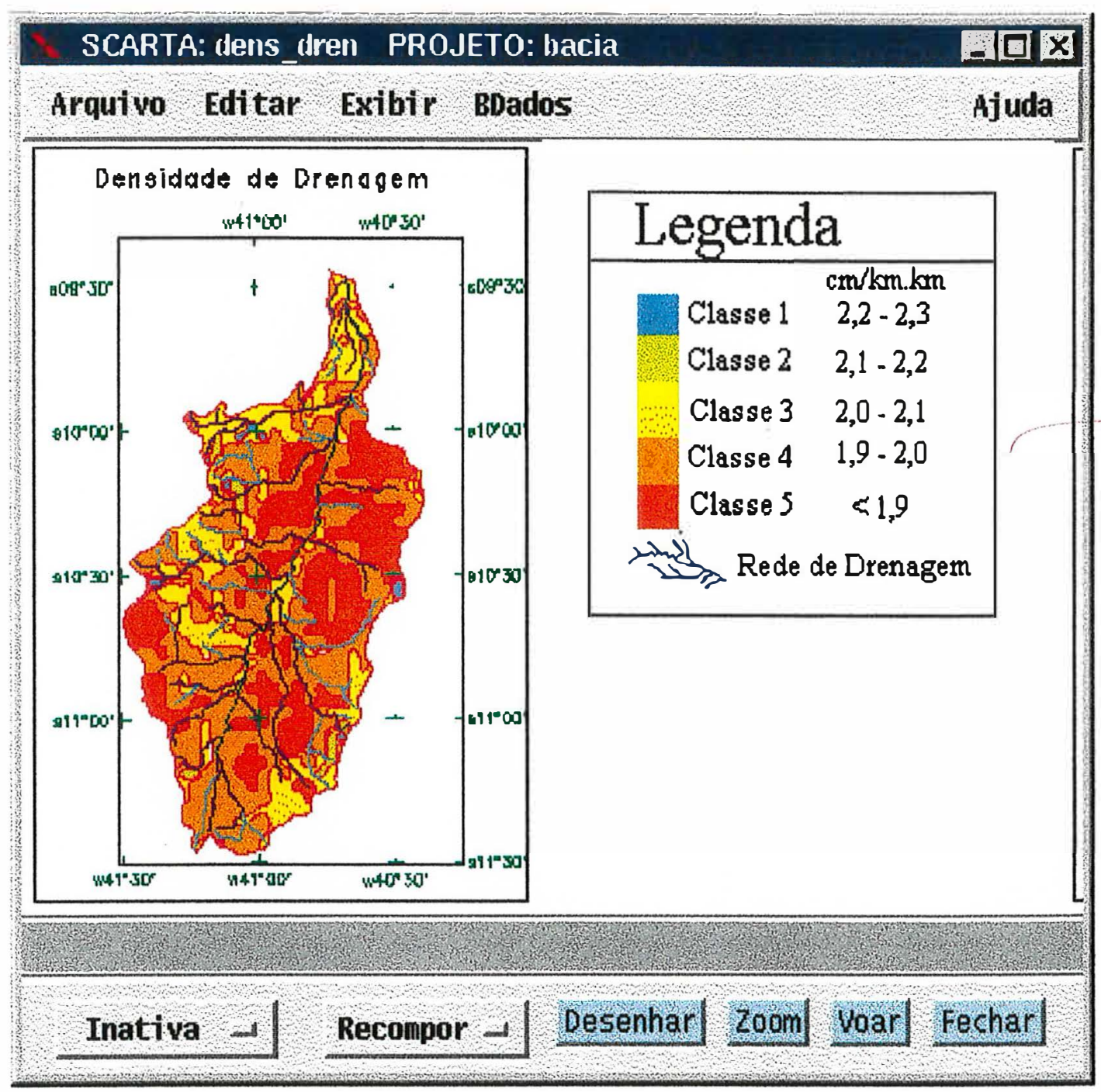

Figura 9 - Classes de Densidade de Drenagem digitalizadas para a formação do Plano de Informação temático Densidade de Drenagem no SPRING.

As áreas com baixa densidade de drenagem compreendem as classes 4 e 5 . São constituídas por terrenos de relevo plano e suave, com afloramentos sedimentares predominantemente calcários, cuja condição de alta permeabilidade permite a rapidez de infiltração de água e a conseqüente formação de lençóis aqüíferos. $\mathrm{O}$ regime fluvial apresenta um escoamento superficial pouco significativo e gera mecanismos de erosão hídrica, ligados 
ao processo inicial da ação da gota de chuva; provoca assim, a erosão laminar ou em lençol, decorrente do atrito do próprio escoamento superficial, que conduz material erodido dos pontos abaixo das encostas para as calhas fluviais, incorporando-se às descargas dos rios.

As áreas de alta densidade correspondem às classes com valor superior a 2,0. Apresentam terrenos com relevo de maior movimentação topográfica, aflorando, nas bordas, os Metassedimentos do grupo Jacobina e, em trechos do baixo curso, o Complexo Paramirim, Barreira, ambos constituídos por rochas de reduzida permeabilidade. Nos trechos mais elevados das bordas da bacia, as isoietas médias anuais chegam a $800 \mathrm{~mm}$. Os rios são efềmeros, existindo apenas durante, ou imediatamente após, as chuvas; não recebem contribuição de lençol aqüífero, exceção feita ao trecho do curso inferior da bacia. $\mathrm{O}$ escoamento mais rápido nas encostas provoca $\mathrm{o}$ aparecimento da ação erosiva em sulco e voçoroca, que, em época de chuvas, abrem grandes fendas, por onde o escoamento concentrado tende a alargar a escavação, progredindo para montante e transformando a voçoroca em ravina (BAHIA, 1986).

O mapa de distribuição da densidade de drenagem, Figura 9, mostra nitidamente que a quase totalidade da bacia possui classes de baixa densidade, concentrando-se as áreas mais rarefeitas em setores situados no centro-leste. As áreas de altas densidades surgem em trechos de ocorrência de maiores elevações, correspondentes aos divisores topográficos e às elevações residuais. No trecho inferior da bacia, onde se forma uma espécie de garganta, incidem também valores de alta densidade, apresentando variações, no que concerne a um regime hídrico mais regular, escoamento lento e calhas fluviais de maior porte. 
3.1.2. Inserção dos dados de caracterização climática da bacia do rio Salitre.

Com base nos dados pluviométricos observados em 21 estações, localizadas no interior e na circunvizinhança da bacia, e referentes ao período de 1912 a 1977, foi caracterizada a distribuição espacial dos totais anuais de chuva, através da rede de isoietas e do déficit hídrico apresentados nas Figuras 10 e 11, respectivamente.

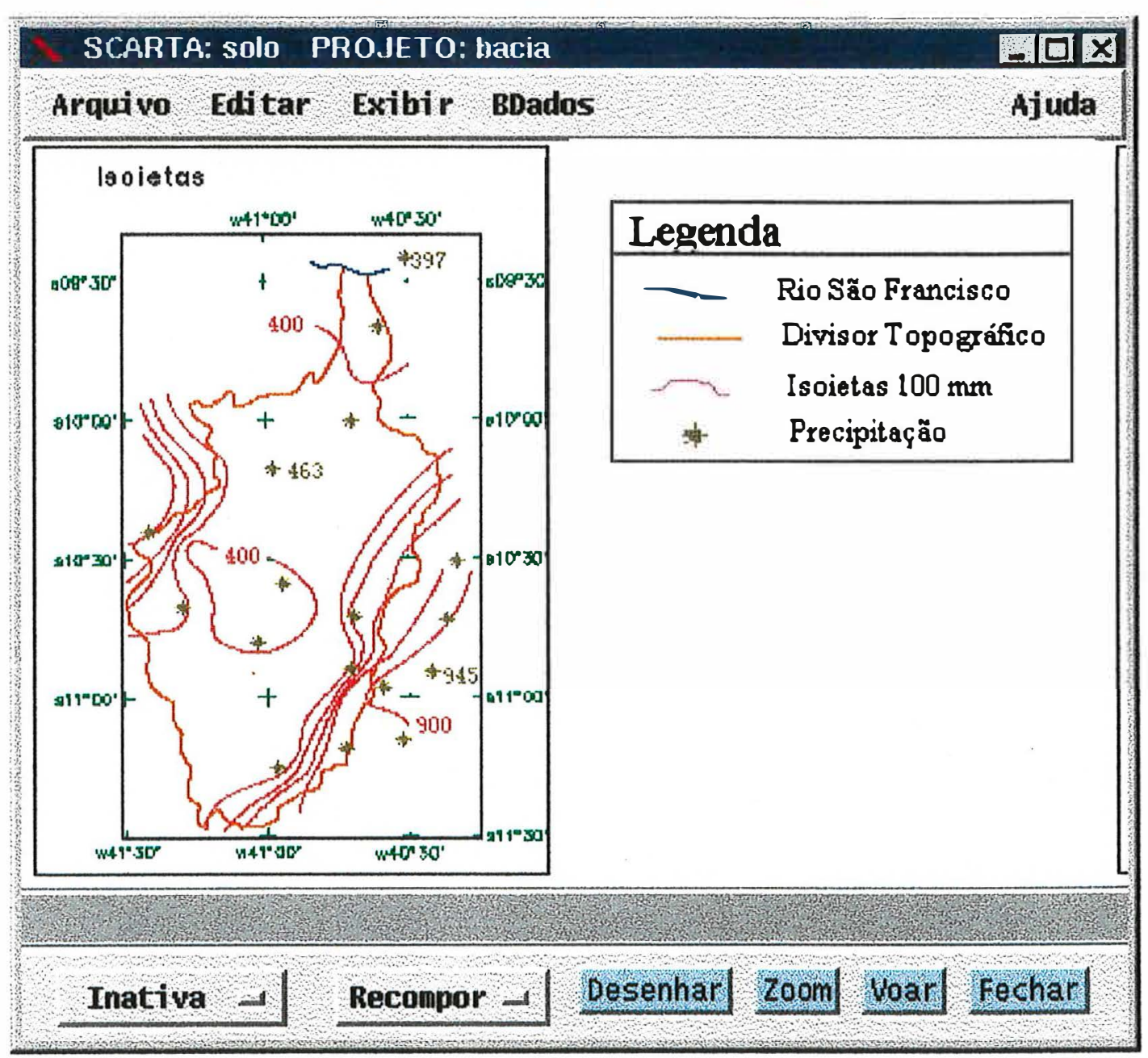

Figura 10 - Plano de Informação da distribuição média das chuvas na bacia do rio Salitre para o período de 1912 a 1977. 


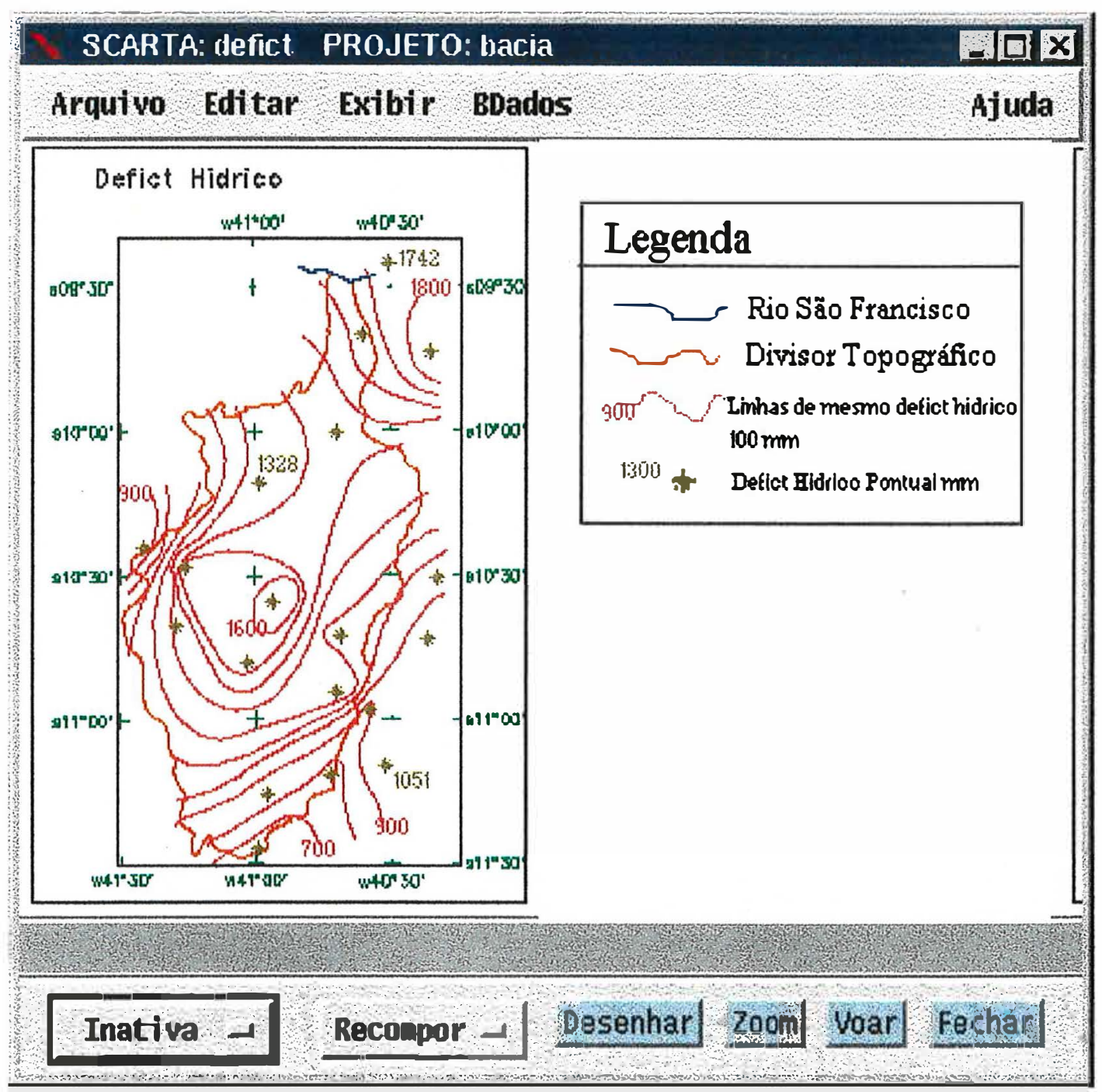

Figura 11 - Plano de Informação da distribuição média do déficit hídrico para o período de 1912 a 1977.

O clima na bacia do rio Salitre é do tipo Bsh'W', segundo a classificação de Koeppen, ou seja, um clima semi-árido, com precipitação média anual inferior a $600 \mathrm{~mm}$ e curta estação chuvosa, temperatura média anual superior a $18^{\circ} \mathrm{C}$ e pouca variação ao longo do ano, o que acarreta altos índices de evaporação e conseqüente déficit hídrico.

Analisando-se a rede de isoietas, observa-se que há uma concentração maior de chuvas nos limites sudeste e oeste da bacia, 
coincidindo com as maiores altitudes. Ao longo dos vales, e na quase totalidade da bacia, os totais anuais oscilam entre 400 e $500 \mathrm{~mm}$.

A precipitação anual média, na bacia, é de $490 \mathrm{~mm}$ e sua distribuição, ao longo do ano, faz-se de forma bastante irregular, com forte concentração nos meses de janeiro a março, quando a precipitação corresponde a cerca de $50 \%$ do total anual, e grande escassez nos meses de junho a setembro, quando, de modo geral, a precipitação é nula. $O$ período chuvoso inicia-se no final do mês de novembro e estende-se até o mês de abril. As Figuras 12 e 13 são gráficos da distribuição espacial das chuvas observadas nas estações de Upamirim, Juazeiro, São Tomé, Morro do Chapéu e Jacobina, e selecionadas em função da distribuição espacial. das chuvas na maior parte da bacia.

Um dos principais fatores a influenciar a produção de precipitação no Nordeste do Brasil é a posição e a intensidade da Zona de Convergência Intertropical (ZCIT). Essa zona é formada pela confluência dos ventos alísios do Hemisfério Norte (alísios de nordeste) e do Hemisfério Sul (alísios de sudeste). Esses ventos advectam umidade para a faixa equatorial, com conseqüentes movimentos ascendentes na banda longitudinal para que convergem. Os movimentos ascendentes provocam a condensação de vapor d'água, com o aparecimento de nuvens numa faixa conhecida como a de mais alta taxa de precipitação do globo terrestre. A faixa de convergência é facilmente reconhecida em fotos de satélites, pela presença quase constante de nebulosidade convectiva. 


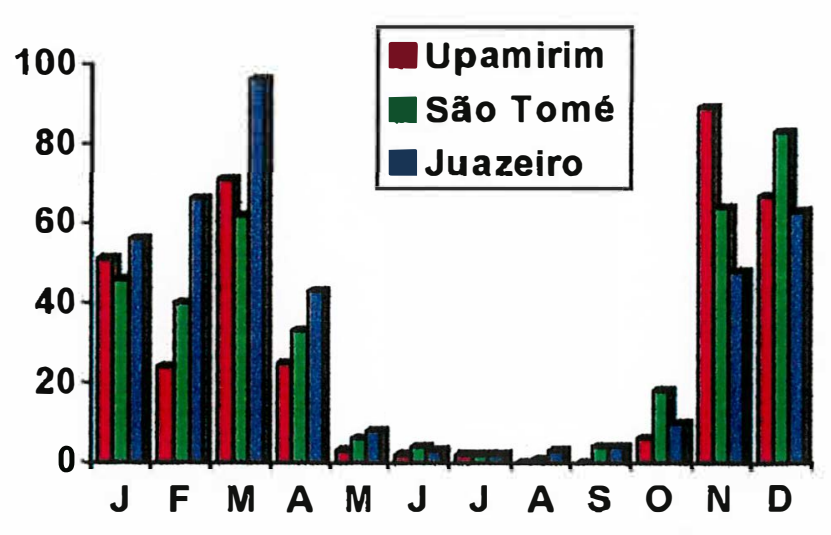

Figura 12 - Distribuição anual das chuvas para as localidades de Upamirim, Juazeiro e São Tomé.

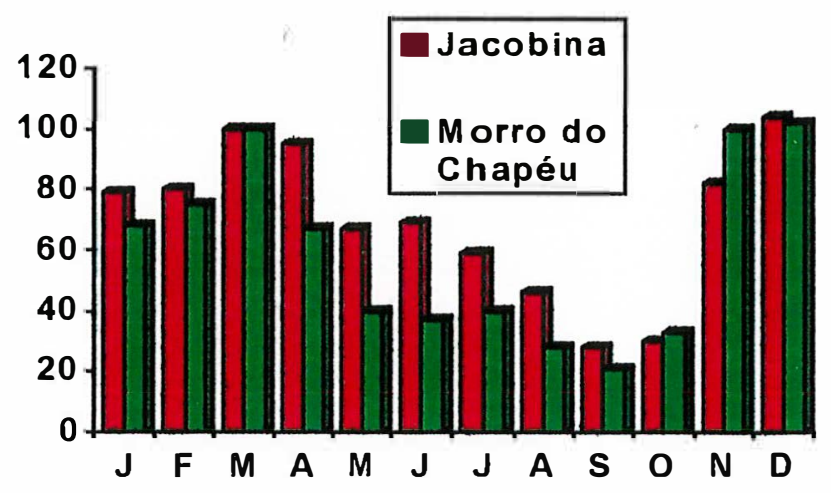

Figura 13 - Distribuição anual das chuvas para Jacobina e Morro do Chapéu.

O eixo da ZCIT varia latitudinalmente durante o ano, e sua atividade depende da circulação geral da atmosfera, bem como do aquecimento da superficie. Esse eixo acompanha o deslocamento aparente do Sol, com um atraso médio de aproximadamente dois meses. Na faixa do Atlântico - América do Sul, sua posição mais ao norte se dá em agosto ou 
setembro, quando alcança $15^{\circ} \mathrm{N}$; sua posição mais ao sul acontece em março ou abril quando chega a $2^{\circ} \mathrm{S}$. Essa posição mais ao sul pode variar em cerca de 3 a $4^{\circ}$ de latitude para norte ou para sul, em alguns anos. Essa variação na posição do eixo da ZCIT está associada com a ocorrência de secas (posição mais ao norte) e chuvas acima da média (posição mais ao sul).

As partes do Nordeste do Brasil que mais sofrem a influência da ZCIT são a norte e a central. Essa sub-região é constituída pelos estados do Maranhão (norte e centro), Piauí (norte e centro), Ceará (todo o estado), sertões do Rio Grande do Norte, Paraíba, Pernambuco e norte-nordeste da Bahia. Nessa grande área o período chuvoso vai de janeiro até junho, com máximos de precipitação durante março e abril. Esses são os dois meses em que a ZCIT alcança sua posição mais ao sul.

O movimento, para o norte, das massas de ar frio provenientes das regiões sub-árticas, constitui, junto com a ZCIT, o principal mecanismo para produzir precipitação no Nordeste do Brasil. A freqüência desses sistemas é, aproximadamente, um por semana, na região sul do Brasil; somente alguns desses sistemas, ou parte deles, penetram mais para o norte. Dessa maneira, são poucos os sistemas que influenciam a precipitação na parte central, norte e leste do Nordeste durante todo o ano.

A parte sul da região nordeste do Brasil, inferior à latitude de $10^{\circ} \mathrm{S}$, ou seja , grande parte do estado da Bahia, deve o maior quinhão de sua precipitação a sistemas frontais que penetram no Brasil, no período de novembro a fevereiro com um pico máximo em dezembro.

Uma vez que a bacia do rio Salitre se encontra no limiar desses dois fenômenos naturais, as diferenças nos gráficos observados para 
distintas localidades na mesma região, evidenciam o processo aditivo dos fenômenos nos meses recorrentes.

A partir dos Pis, digitalizados, de precipitação e de déficit hídrico, foram gerados, de forma automática, por média simples entre os pontos, grades de modelo numérico do terreno, utilizando-se o SPRING. Com a obtenção dessas grades, viabilizou-se a construção de um plano de informação temático, para diferentes faixas de precipitação e de déficit hídrico. Tais planos formaram a base de entrada de dados climáticos no esquema conceitual, para a análise simulada de um modelo de recuperação e de resposta produtiva de cultivos aos efeitos da salinidade da água e do solo.

A Figura 15 mostra o plano temático de precipitação, gerado a partir dos dados de modelo numérico, visualizados na Figura 10. Observe que foi realizada uma superposição de planos na Figura 15, entre o plano temático gerado para a formação da composição de cores e o modelo numérico de terreno (MNT) da Figura 10. Ela foi realizada no intuito de melhor visualizar a distribuição dos índices pluviométricos na região.

A Figura 16, como a figura 15, remete a uma superposição entre o plano temático, gerado de forma automática por média simples, através do SPRING, e o MNT para o déficit hídrico observado na Figura 11. Os espaços em branco, observados na Figura 15, representam áreas com reduzida homogeneidade dos dados, devido à utilização de uma linha de quebra no divisor topográfico da bacia.

A Figura 17 apresenta uma homogeneização do plano de informação, gerado na Figura 16, pela supressão da linha de quebra. A supressão permite que o algoritmo de interpolação analise o retângulo envolvente sob a forma contínua, extrapolando as informações para fora do 
limite estabelecido pela linha de quebra, representativa do divisor de águas da bacia.

A variação inter-anual da precipitação é expressiva, apresentando a série de valores anuais analisados coeficiente de variação de $40 \%$. A seqüência dos 5 anos mais secos na região correspondem ao período de 1951 a 1955, enquanto o período mais úmido corresponde aos anos de 1964 a 1968 (BAHIA, 1986).

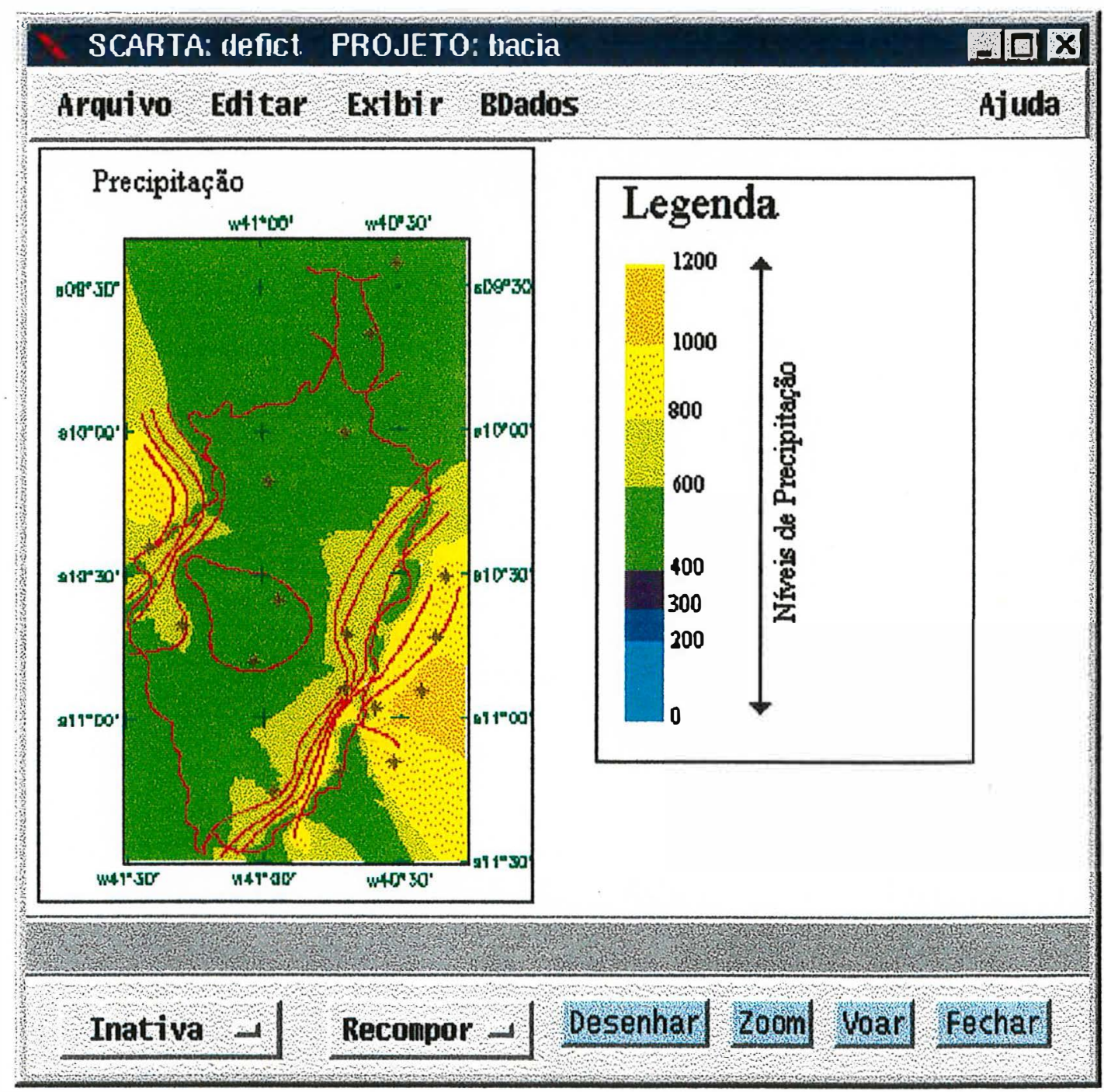

Figura 15 - Composição entre o plano temático dos níveis de precipitação e o seu MNT . 
A temperatura média anual, na bacia, é de cerca de $23^{\circ} \mathrm{C}$, aumentando de montante para jusante $\left(19^{\circ} \mathrm{C} \mathrm{em}\right.$ Morro do Chapéu e $26^{\circ} \mathrm{C} \mathrm{em}$ Juazeiro). A amplitude térmica anual é da ordem de $5^{\circ} \mathrm{C}$, sendo julho o mês mais frio, e janeiro e setembro, os mais quentes.

A umidade relativa é de cerca de $70 \%$, apresentando valor mínimo em outubro, aproximadamente $67 \%$, e máxima em julho, em torno de 73\% (BAHIA, 1986).

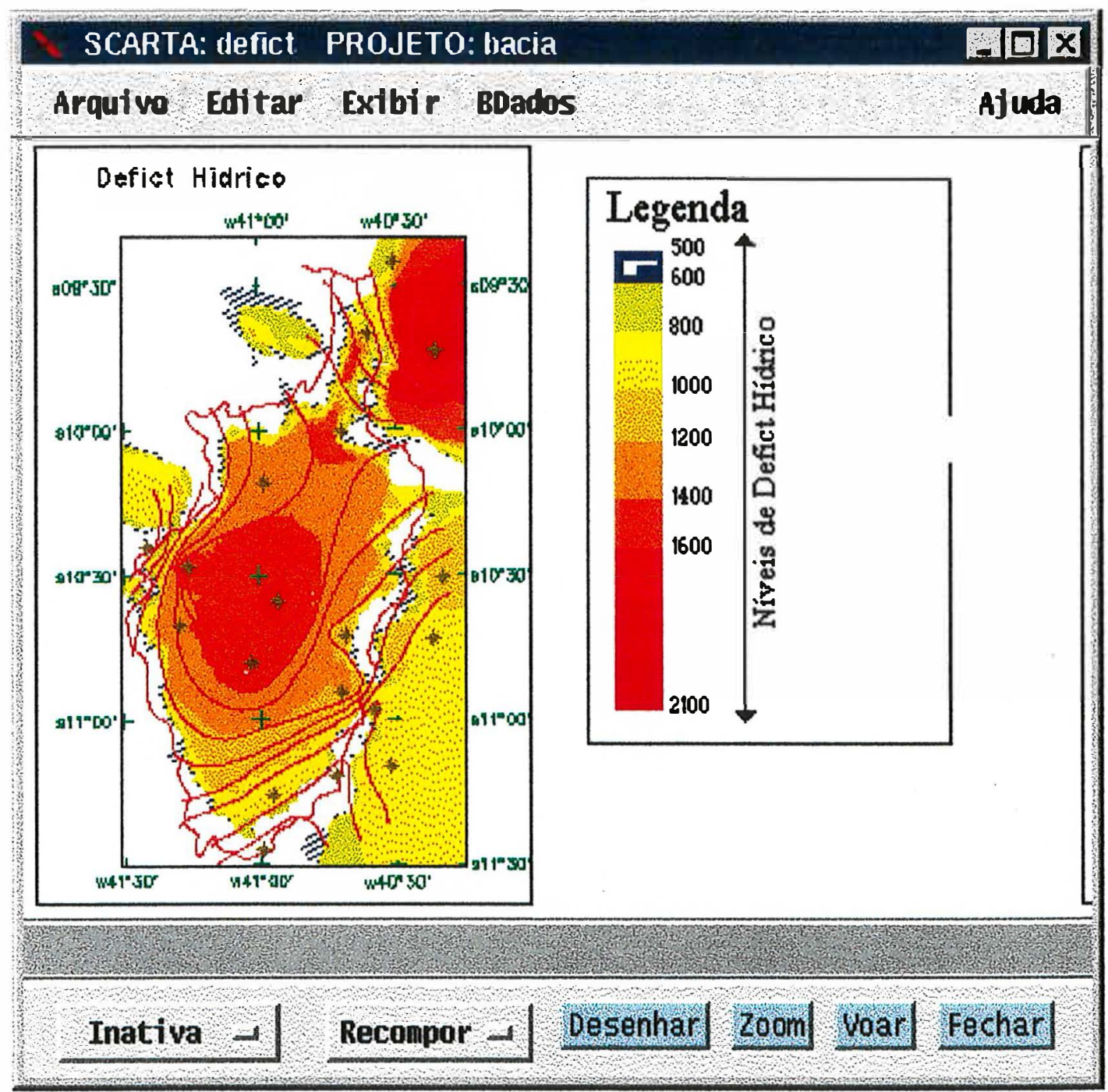

Figura 16 - Composição entre o plano temático dos níveis de déficit hídrico e o seu MNT. 
A bacia do rio Salitre, da mesma maneira que o nordeste semiárido está sujeita a forte insolação. O número médio de horas de exposição ao sol por dia é de 7,7 horas, atingindo um máximo de 9 horas no mês de outubro e o mínimo de 7 horas em julho.

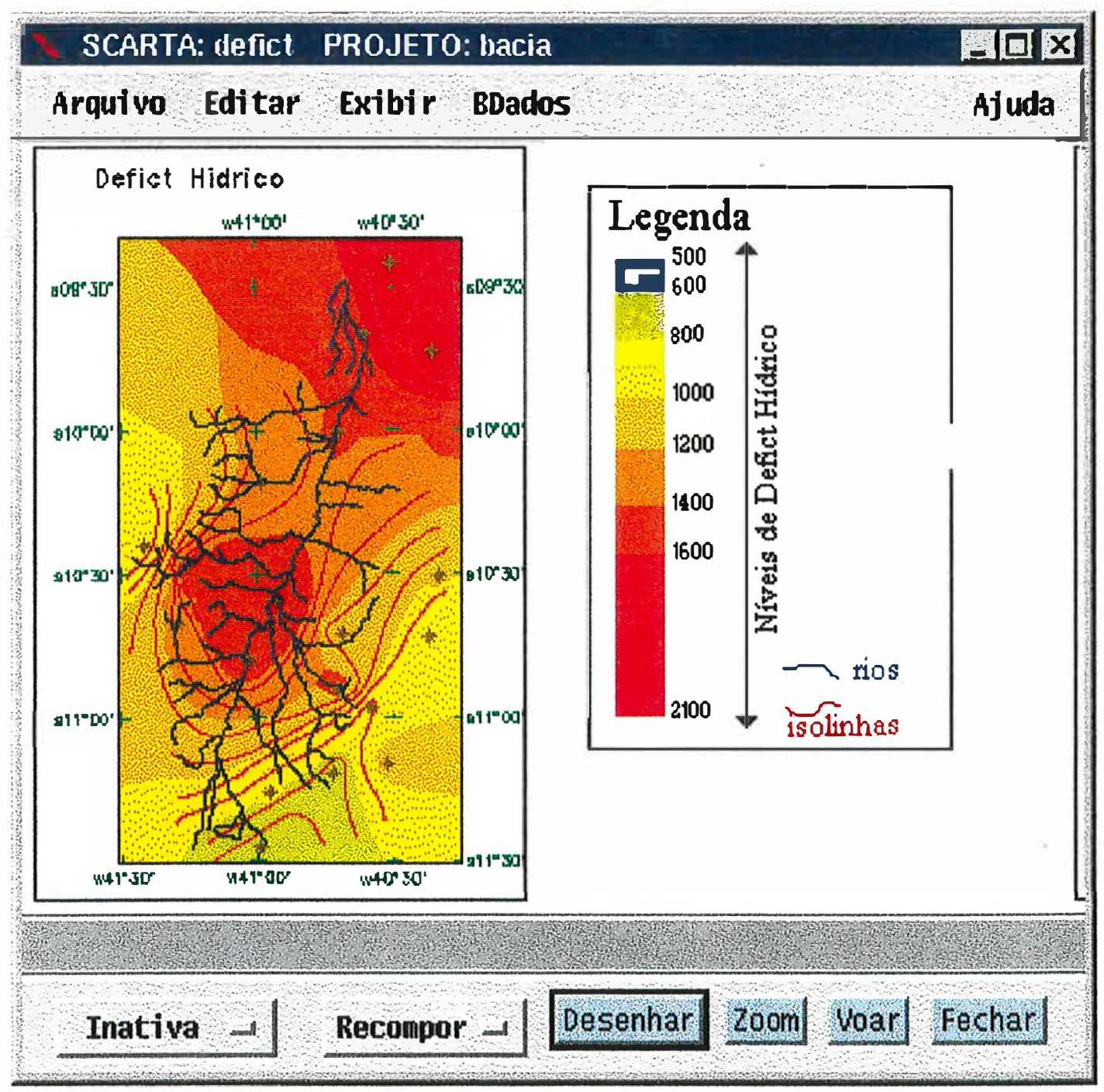

Figura 17 - Superposição dos planos de informação temático hidrologia, temático de classes de déficit hídrico e de modelo numérico de terreno do déficit hídrico, sem a linha de quebra do divisor topográfico.

Com base nos dados observados nas estações de Juazeiro, Jacobina e Morro do Chapéu, conclui-se que os ventos na região apresentam a 
direção predominante de leste e sudeste e a velocidade média de cerca de 3,0 $\mathrm{m} / \mathrm{s}$.

Devido à alta temperatura, ao longo de todo o ano, e à forte insolação, o vale do rio Salitre apresenta elevado índice evaporimétrico que, em conjunto com a baixa pluviosidade, aumenta consideravelmente o risco de sucesso na atividade agrícola, dependente de chuvas e sob irrigação.

$\mathrm{O}$ balanço agroclimático visa a determinar as necessidades hídricas para o plantio, envolvendo as variáveis relativas à evapotranspiração, a quantidade de água absorvida pelo solo e posta à disposição da planta, a quantidade de água armazenada no solo e o excesso de água precipitada, que dá origem ao escoamento superficial.

$\mathrm{O}$ déficit hídrico, segundo os conceitos que envolvem a aplicação do balanço agroclimático, vem representar a água que deixa de ser evapotranspirada, pela insuficiência de umidade do solo; corresponde a uma quantificação da ação climática e permite avaliações preliminares das necessidade de água de irrigação. $O$ déficit hídrico foi obtido a partir dos resultados do balanço agroclimático, realizados para as localidades selecionadas no interior e circunvizinhanças da bacia do rio Salitre.

A Figura 18 mostra a distribuição dos dados de evaporação determinados por interpolação com o $\quad$ SPRING de 21 estações evaporimétricas presentes no interior da bacia e nas regiões circunvizinhas. Os fortes níveis de evaporação, observados ao longo de toda a região, pressupõem a necessidade de métodos de controle da salinidade da água aplicada e da lixiviação de sais, além de estruturas que visem ao abastecimento das populações, como reservatórios e poços. No caso dos poços, importa estabelecer seus níveis de salinidade para o abastecimento 
humano e animal, além do uso dessas águas na agricultura. Métodos alternativos de redução dos índices de evaporação como a utilização de irrigação localizada, o mulching, cultivos arbustivos em consórcio com cultivos arbóreos, podem ser viáveis sob condições localizadas.

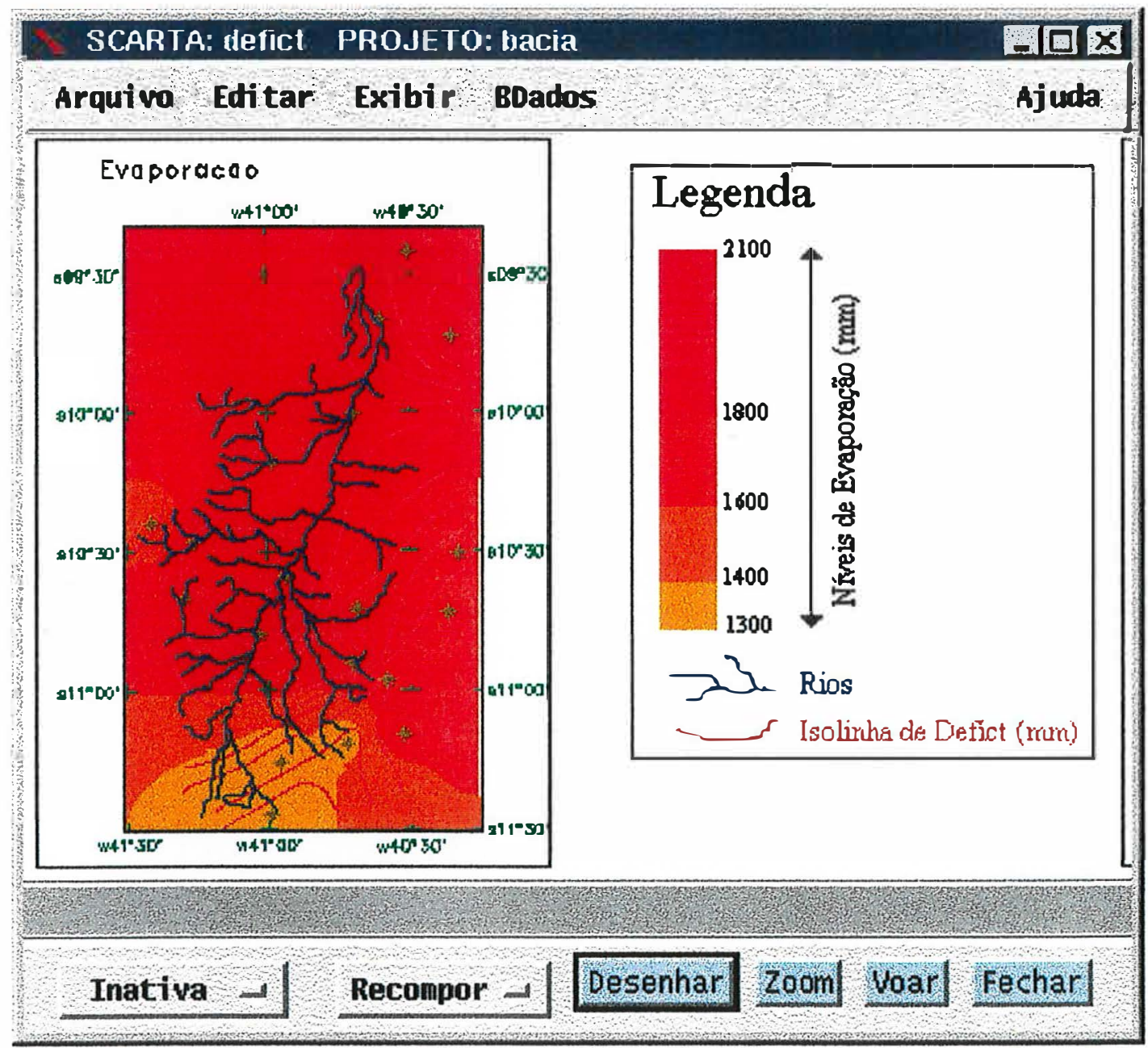

Figura 18 - Superposição dos planos de informação temático hidrologia, temático de classes de evaporação e de modelo numérico de terreno do déficit hídrico sem a linha de quebra do divisor topográfico.

Um outro aspecto importante a considerar em relação aos elevados índices de evaporação, é a exposição do solo entre cultivos sucessivos. A irrigação que utiliza métodos de superficie, como a irrigação 
por sulcos, em conjunto com a exposição das terras entre os cultivos, constitui forte fator de progressão do fenômeno da salinidade, principalmente quando o manejo da irrigação é inadequado e apresenta baixa eficiência de armazenamento e de distribuição.

3.1.3. Plano de informação sobre salinidade das águas superficiais e subterrâneas.

Os solos das zonas semi-áridas, onde a evaporação é alta e a pluviosidade, é baixa, quando submetidos à irrigação, sujeitam-se a um aumento no teor de sais solúveis e sódio trocável, dependendo, entretanto, das características do solo, da qualidade da água e do manejo agrícola.

A qualidade da água e os fertilizantes são fatores que se devem considerar no manejo das áreas irrigadas, pois podem contribuir, de modo acentuado, para o aumento da salinidade e da quantidade de sódio trocável nos solos, principalmente aqueles de textura argilosa, com camadas endurecidas e baixa condutividade hidráulica.

Os sais solúveis, em alta concentração, afetam o desenvolvimento das plantas sob dois aspectos: o aumento da pressão osmótica do meio, dificultando a retirada de água do solo pela planta e, com seu efeito tóxico, reduzindo a produtividade do cultivo. Conclui-se, assim, que a baixa qualidade das águas superficiais e subterrâneas constitui fator limitante ao pleno desenvolvimento agrícola de uma dada área.

As características mais importantes para determinar a qualidade da água de irrigação são a concentração de sais solúveis e a 
concentração de sódio em relação a outros cátions. A concentração total de sais solúveis para fins de diagnóstico e de classificação, pode ser expressa em termos da condutividade elétrica. As águas são divididas em quatro classes, de acordo com a sua condutividade elétrica, sendo os pontos de divisão entre essas classes os valores de 250,750 e $2.250 \mu \mathrm{mhos} / \mathrm{cm}$.

As águas usadas para irrigação devem de um modo geral, ter uma condutividade elétrica inferior a $2.250 \mu \mathrm{mhos} / \mathrm{cm}$. O uso de águas com concentrações superiores a esta é possível, com o uso de modernas tecnologias de manejo, de filtragem e de aplicação, que envolvem elevados investimentos e custos operacionais, porém com resultados satisfatórios.

As águas cuja condutividade elétrica varia entre 750 e 2.250 $\mu$ mhos/cm são utilizadas, obtendo-se ,com elas, o crescimento adequado das plantas, sendo necessário, porém, um bom manejo da terra e uma drenagem eficiente. Existirá o perigo de salinização dos solos, se a lixiviação de sais e a drenagem não forem adequadas (BAHIA, 1986).

Em geral, as águas cuja condutividade elétrica é inferior a 750 $\mu \mathrm{mhos} / \mathrm{cm}$ são as mais indicadas para a irrigação, ainda que cultivos sensíveis sejam afetados adversamente, quando se usam águas de condutividade variável entre 250 e $750 \mu \mathrm{mhos} / \mathrm{cm}$.

A proporção relativa entre o sódio e outros cátions na água de irrigação pode ser expressa pela razão de adsorsão de sódio (RAS), que é fornecida pela relação

$$
\mathbf{R A S}=\frac{\mathbf{N a}^{+}}{\sqrt{\frac{\mathrm{Ca}^{++}+\mathbf{M g}^{++}}{2}}}
$$


onde $\mathrm{Na}^{+}$é a concentração de sódio em $\mathrm{mg} / \mathrm{l} ; \mathbf{C a}^{++}$, a concentração de cálcio em mg/l e $\mathbf{M g}^{++}$, a concentração de magnésio em mg/l.

A classificação das águas de irrigação, em relação a RAS, baseia-se, primordialmente, no efeito que tem o sódio intercambiável sobre as condições físicas do solo. Em solos de textura leve, o sódio representa um perigo considerável, acentuado, caso esses solos possuam uma alta capacidade de intercâmbio de cátions, especialmente sob condições de lavagem deficientes. Ocasionalmente, a água de irrigação pode colocar, em solução, uma boa porcentagem de cálcio nos solos calcários, de tal maneira, que diminui notavelmente o perigo de sodificação, porém aumenta o riso de salinização por cálcio ou magnésio.

A Tabela 2 apresenta um cadastro dos pontos de água perfurados, no vale do rio Salitre, com a coordenada geográfica, a profundidade do poço, a vazão, o teor de sólidos totais dissolvidos (STD) e a concentração de cálcio, magnésio, sódio, além do $\mathrm{pH}$ e da condutividade elétrica da água.

A Figura 19 apresenta os dados digitalizados do zoneamento da salinidade total da bacia do rio Salitre utilizando-se o SPRING. Com base nos dados georreferenciados do teor de sólidos totais das águas superficiais e subterrâneas da bacia, foram estabelecidas as condutividades elétricas prováveis regionalizadas das águas de irrigação, conforme procedimento estabelecido pela SEPLANTEC (BAHIA, 1986) e conforme os métodos estabelecidos pôr Rhoades et al. (1992) para a conversão dos sólidos dissolvidos totais em condutividade elétrica. 
Tabela 2 - Cadastro das análises químicas de poços da bacia do rio Salitre.

\begin{tabular}{|c|c|c|c|c|c|c|c|c|c|c|c|}
\hline $\mathrm{N}^{\circ}$ & ANO & $\mathbf{L A T ^ { 1 }}$ & LONG ${ }^{2}$ & $\begin{array}{c}\text { PROF }^{3} \\
\text { (m) }\end{array}$ & $\begin{array}{l}Q^{4} \\
(1 / s)\end{array}$ & pH & $\begin{array}{c}\mathrm{CE}^{4} \\
\mu \mathrm{mhos} / \mathrm{cm}\end{array}$ & $\begin{array}{l}\text { STD }^{5} \\
\mathrm{mg} / 1\end{array}$ & $\underset{\mathrm{mgh}}{\mathrm{Ca}}$ & $\begin{array}{l}\text { Mg } \\
\text { mg/l }\end{array}$ & $\begin{array}{c}\mathrm{Na} \\
\mathrm{mg} /\end{array}$ \\
\hline 1 & 1984 & $40^{\circ} 38^{\prime} 41^{\prime \prime}$ & 9'37'37" & 60 & & 6,9 & 1800 & 1316 & 144 & 87 & 58,3 \\
\hline 2 & 1984 & $40^{\circ} 38^{\prime} 54^{\prime \prime}$ & 932'39"' & 45 & & 7,2 & 2950 & 2096 & 147 & 105 & 270 \\
\hline 3 & & $40^{\circ} 37^{\prime} 52^{\prime \prime}$ & $9^{\circ} 55^{\prime 25}$ & 8,5 & & 7,5 & 1600 & 1024 & 135 & 62 & 78,3 \\
\hline 4 & & $40^{\circ} 41^{\prime} 40^{\prime \prime}$ & 9054'43"' & & & 7,4 & 635 & 356 & 60 & 28 & 2,2 \\
\hline 5 & 1980 & $41^{\circ} 14^{\prime} 36^{\prime \prime}$ & $10^{\circ} 28^{\prime} 21^{\prime \prime}$ & 80 & 2,5 & 5,8 & 155 & 174 & 8,8 & 2,4 & 11,5 \\
\hline 6 & 1984 & $41^{\circ} 06^{\prime} 18^{\prime \prime}$ & $10^{\circ} 27^{\prime} 47^{\prime \prime}$ & 90 & 3,38 & 5,7 & 122 & 106 & 6,4 & 0,48 & 12,6 \\
\hline 7 & & $41^{\circ} 12^{\prime} 23^{\prime \prime}$ & $10^{\circ} 27^{\prime} 26^{\prime \prime}$ & 70 & 5,0 & 7,3 & 300 & 188 & 29,6 & 11,2 & 8,6 \\
\hline 8 & & $40^{\circ} 59^{\prime} 16^{\prime \prime}$ & $10^{\circ} 11^{\prime} 32^{\prime \prime}$ & 49,5 & 4,0 & 6,6 & 1120 & 928 & 80 & 24,3 & 50,2 \\
\hline 9 & 1983 & $40^{\circ} 37^{\prime} 31^{\prime \prime}$ & $1024 ' 02 "$ & 118 & 2,68 & 6,7 & 1860 & 1560 & 192 & 63 & 141,5 \\
\hline 10 & 1984 & $40^{\circ} 24^{\prime} 34^{\prime \prime}$ & $10^{\circ} 28^{\prime} 18^{\prime \prime}$ & 85 & 0,44 & 7,1 & 4400 & 4260 & 400 & 146 & 451 \\
\hline 11 & 1984 & 4037'57'" & $10^{\circ} 07^{\prime} 01 "$ & 100 & 0,28 & 6,9 & 850 & 592 & 97 & 42 & 20,9 \\
\hline 12 & & $40^{\circ} 35^{\prime} 51 "$ & 1009'02"' & 50 & & 7,4 & 1000 & 670 & 124 & 42 & 28,8 \\
\hline 13 & & $40^{\circ} 50^{\prime} 41^{\prime \prime}$ & $10^{\circ} 26^{\prime} 18^{\prime \prime}$ & & & 7,0 & 1280 & 1026 & 132 & 40 & 7,3 \\
\hline 14 & 1980 & $41^{\circ} 16^{\prime} 15^{\prime \prime}$ & $10^{\circ} 53^{\prime} 28^{\prime \prime}$ & 120 & 1,46 & 6,7 & 1930 & 1390 & 120 & 104 & 149,5 \\
\hline 15 & 1980 & 4119’07' & 1053'56" & 60 & 2,65 & 6,7 & 1310 & 848 & 184 & 41,3 & 37,3 \\
\hline 16 & & $41^{\circ} 19^{\prime} 51^{\prime \prime}$ & $10^{\circ} 44^{\prime} 04^{\prime \prime}$ & 60 & 3,01 & 7,4 & 1940 & 1588 & 122 & 58 & 276,5 \\
\hline 17 & & $41^{\circ} 02^{\prime} 00^{\prime \prime}$ & $10^{\circ} 58^{\prime} 21^{\prime \prime}$ & 106 & & 7,5 & 868 & 522 & 28 & 9,7 & 169,3 \\
\hline 18 & 1983 & $41^{\circ} 00^{\prime} 24^{\prime \prime}$ & $10^{\circ} 42^{\prime} 34^{\prime \prime}$ & 33 & 0,46 & 6,8 & 1370 & 1208 & 94 & 42 & 98,7 \\
\hline 19 & 1977 & $41^{\circ} 18^{\prime} 28^{\prime \prime}$ & $10^{\circ} 49^{\prime} 20^{\prime \prime}$ & 73 & 4,4 & 7,0 & 1730 & 1252 & 162 & 71 & 157,4 \\
\hline 20 & & $41^{\circ} 23^{\prime} 10^{\prime \prime}$ & 10'51'03" & 180 & 1,3 & 7,5 & 1600 & 1026 & 89,7 & 62 & 190,6 \\
\hline 21 & 1984 & $41^{\circ} 15^{\prime} 51^{\prime \prime}$ & $10^{\circ} 48^{\prime} 41^{\prime \prime}$ & 85 & & 7,1 & 2830 & 2338 & 230 & 136 & 195 \\
\hline 22 & 1981 & $40^{\circ} 50^{\prime} 32^{\prime \prime}$ & $10^{\circ} 44^{\prime} 19^{\prime \prime}$ & 100 & 0,56 & 6,7 & 3370 & 3024 & 239 & 129 & 316 \\
\hline 23 & 1983 & $40^{\circ} 38^{\prime} 04^{\prime \prime}$ & $10^{\circ} 44^{\prime} 13^{\prime \prime}$ & 120 & 0,49 & 7,4 & 614 & 318 & 44 & 22 & 46 \\
\hline 24 & 1984 & $40^{\circ} 50^{\prime} 10^{\prime \prime}$ & $10^{\circ} 37^{\prime} 57^{\prime \prime}$ & 34 & 1,94 & 7,2 & 730 & 424 & 72 & 32 & 29 \\
\hline 25 & 1984 & $40^{\circ} 50^{\prime} 46^{\prime \prime}$ & $10^{\circ} 42^{\prime} 16^{\prime \prime}$ & 98 & 0,71 & 7,8 & 941 & 610 & 47 & 38 & 97,1 \\
\hline 26 & 1972 & $40^{\circ} 41^{\prime} 18^{\prime \prime}$ & $10^{\circ} 56^{\prime} 25^{\prime \prime}$ & 90 & & 7,9 & 742 & 644 & 56 & 31 & 49,5 \\
\hline 27 & & $40^{\circ} 32^{\prime} 03^{\prime \prime}$ & $10^{\circ} 31^{\prime} 30^{\prime \prime}$ & 90 & 0,22 & 7,1 & 7500 & 7000 & 621 & 207 & 1018 \\
\hline 28 & 1984 & $40^{\circ} 40^{\prime} 39^{\prime \prime}$ & $10^{\circ} 45^{\prime} 02^{\prime \prime}$ & 180 & 0,16 & 7,2 & 2850 & 2536 & 288 & 132 & 217 \\
\hline 29 & 1977 & $41^{\circ} 01^{\prime} 09^{\prime \prime}$ & $11^{\circ} 12^{\prime} 42^{\prime \prime}$ & 100 & 0,85 & 7,2 & 3320 & 2836 & 199 & 126 & 403,4 \\
\hline 30 & 1979 & 4104'27'" & $11^{\circ} 16^{\prime} 45^{\prime \prime}$ & 48 & 2,93 & 7,3 & 2660 & 2394 & 261 & 169 & 244,7 \\
\hline 31 & 1983 & $41^{\circ} 06^{\prime} 12^{\prime \prime}$ & $11^{\circ} 13^{\prime} 52^{\prime \prime}$ & 36 & 2,0 & 6,9 & 1260 & 904 & 128 & 33 & 79,6 \\
\hline 32 & & $41^{\circ} 05^{\prime} 32^{\prime \prime}$ & $11^{\circ} 05^{\prime} 32^{\prime \prime}$ & 123 & 0,39 & 8,1 & 2080 & 1500 & 104 & 63 & 340 \\
\hline 33 & 1974 & $40^{\circ} 41^{\prime 2} 24^{\prime \prime}$ & $11^{\circ} 19^{\prime} 30^{\prime \prime}$ & 24 & 1,23 & 5,3 & 86 & 272 & 4,0 & 1,2 & 7,0 \\
\hline 34 & 1979 & 40'55'03" & $11^{\circ} 15^{\prime} 42^{\prime \prime}$ & 150 & 1,25 & 7,6 & 3650 & 1640 & 256,3 & 174,9 & 273 \\
\hline 35 & 1980 & $40^{\circ} 46^{\prime} 43^{\prime \prime}$ & $11^{\circ} 03^{\prime} 12^{\prime \prime}$ & 115 & 0,25 & 7,3 & 4140 & 3390 & 424,5 & 131,2 & 324 \\
\hline 36 & 1983 & $40^{\circ} 52^{\prime} 21^{\prime \prime}$ & $11^{\circ} 18^{\prime} 56^{\prime \prime}$ & 150 & 0,27 & 7,5 & 1510 & 870 & 68 & 31,6 & 209 \\
\hline 37 & 1983 & $40^{\circ} 50^{\prime} 08^{\prime \prime}$ & $11^{\circ} 11^{\prime} 00^{\prime \prime}$ & 120 & 1,02 & 7,4 & 2540 & 2172 & 136 & 120 & 183,5 \\
\hline 38 & 1983 & $40^{\circ} 48^{\prime} 54^{\prime \prime}$ & $11^{\circ} 13^{\prime} 52^{\prime \prime}$ & 78 & 6,47 & 7,6 & 380 & 102 & 33,6 & 17,5 & 11,7 \\
\hline 39 & 1983 & $40^{\circ} 48^{\prime} 48^{\prime \prime}$ & 1107'58'" & 150 & 1,57 & 7,0 & 6300 & 6248 & 400 & 364 & 575 \\
\hline 40 & 1972 & $40^{\circ} 56^{\prime} 42^{\prime \prime}$ & $11^{\circ} 15^{\prime} 34^{\prime \prime}$ & 62 & 3,0 & 5,6 & 1730 & 1440 & 152,2 & 26,7 & 153,4 \\
\hline 41 & & 40'59'30" & 1109'33" & 81 & 4,0 & 7,1 & 2400 & 1896 & 272 & 46,2 & 173,3 \\
\hline 42 & 1972 & $40^{\circ} 05^{\prime} 12$ & $11^{\circ} 16^{\prime} 27^{\prime \prime}$ & 70 & 1,25 & 7,7 & 730 & 384 & 64 & 32 & 23,7 \\
\hline
\end{tabular}

Fonte: BAHIA, 1986.

1-LAT=Latitude; 2-LONG=Longitude;3-PROF=profundidade em m; 4-Q=vazão em l/s, pH=potencial Hidrogeniônico;5-CE=Condutividade Elétrica em mmhos/cm;6-STD = Sólidos Dissolvidos Totais em $\mathrm{mg} / \mathrm{l}, \mathrm{Ca}, \mathrm{Mg}$ e $\mathrm{Na}=$ teores de cálcio, magnésio e sódio em $\mathrm{mg} / \mathrm{l}$, respectivamente. 


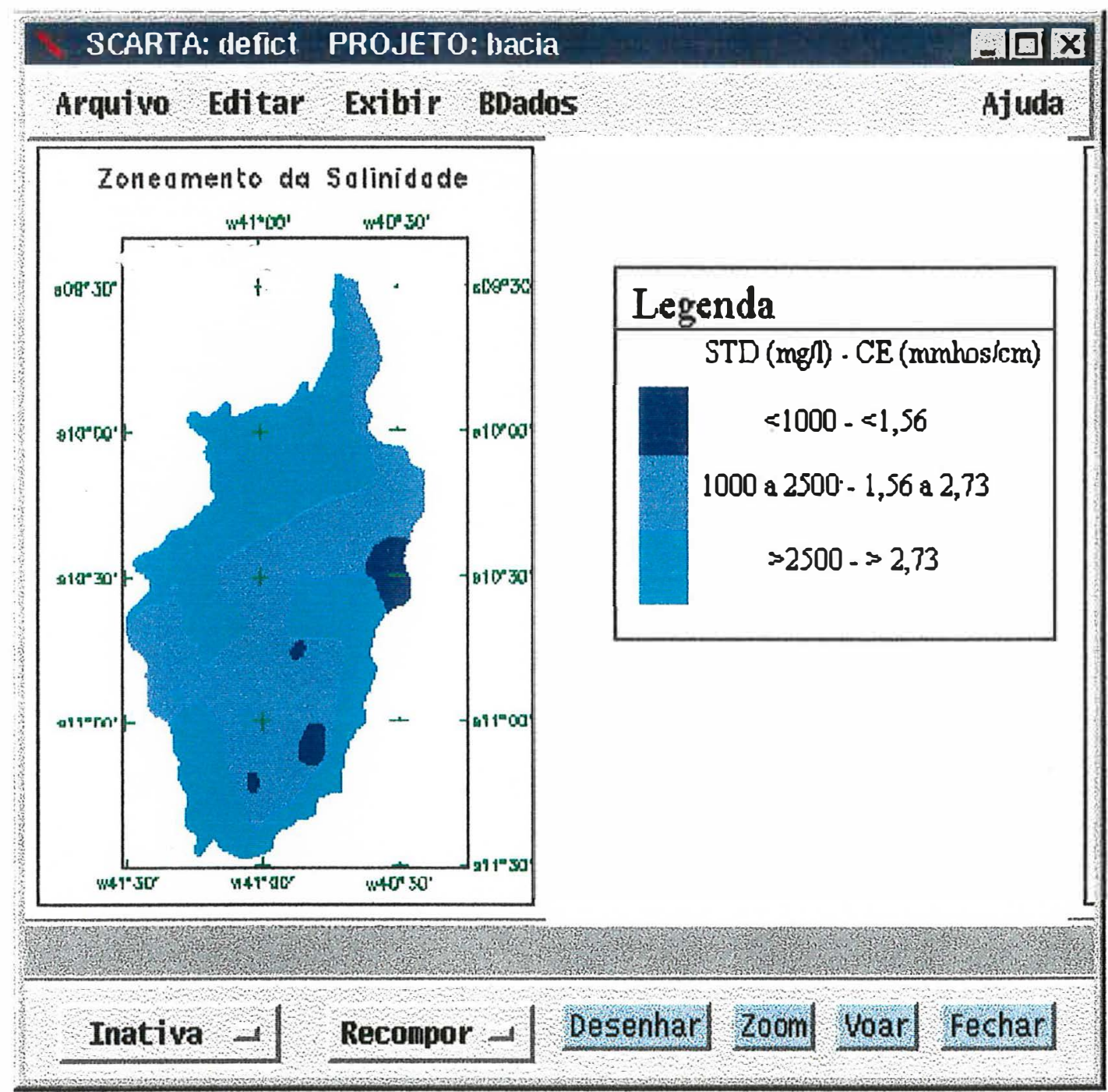

Figura 19 - Plano de informação sobre o zoneamento da salinidade das águas subterrâneas e superficiais da bacia do rio Salitre em relação à quantidade de sólidos dissolvidos totais.

3.1.4. Plano de informação sobre o zoneamento agroecológico.

O estudo integrado de uma bacia, com vistas ao planejamento sob múltiplos objetivos, e numa perspectiva dinâmica, permite verificar o melhor desempenho hídrico, compatível com o desenvolvimento regional 
pretendido. Essa é uma forma nova e mais ampla de se realizar o planejamento de recursos hídricos, por bacia hidrográfica. Anteriormente, os estudos visavam a objetivos simples ou parciais, restringindo-se à otimização de um único uso de água, ou de um único aproveitamento.

Dentro dessa nova ótica de planejamento integrado de toda a bacia, existe a necessidade de se destacar em frações interiores às unidades hidrográficas, definidas pela análise do meio físico. Elas corresponderão às microregiões, sub-bacias ou zonas homogêneas, com características ou problemas semelhantes, e permitirão uma análise conjunta dessas áreas, procurando-se atingir o equilíbrio ideal entre recursos hídricos e desenvolvimento.

O estudo do meio físico, apresentado nos planos de informação anteriores, buscou essencialmente estruturar uma regionalização, para efeito do planejamento dos recursos hídricos. A divisão em zonas homogêneas foi o procedimento utilizado pela SPLANTEC (BAHIA, 1986), para definir um zoneamento agroecológico integrado de toda a bacia, e teve, por objetivo, dividir o espaço territorial em unidade geográficas regionais e sub-regionais que, facilitassem o processo de fommulação de um plano de ação.

O principal critério de fracionamento é o fisiográfico, e, dentre as características fisiográficas, a hidrografia desempenha o papel principal. As características climáticas, geológicas, geomorfológicas e edafológicas foram consideradas fatores adicionais no processo de regionalização. DesSa forma, a bacia foi subdividida em zonas hidrológicamente homogêneas, zonas fisiográficas homogêneas e zonas susceptíveis à erosão (BAHIA, 1986). 
A Figura 20 mostra os dados de regionalização agroecológica, para o modelo de simulação da resposta produtiva dos cultivos, considerandose o zoneamento agroclimático estabelecido.

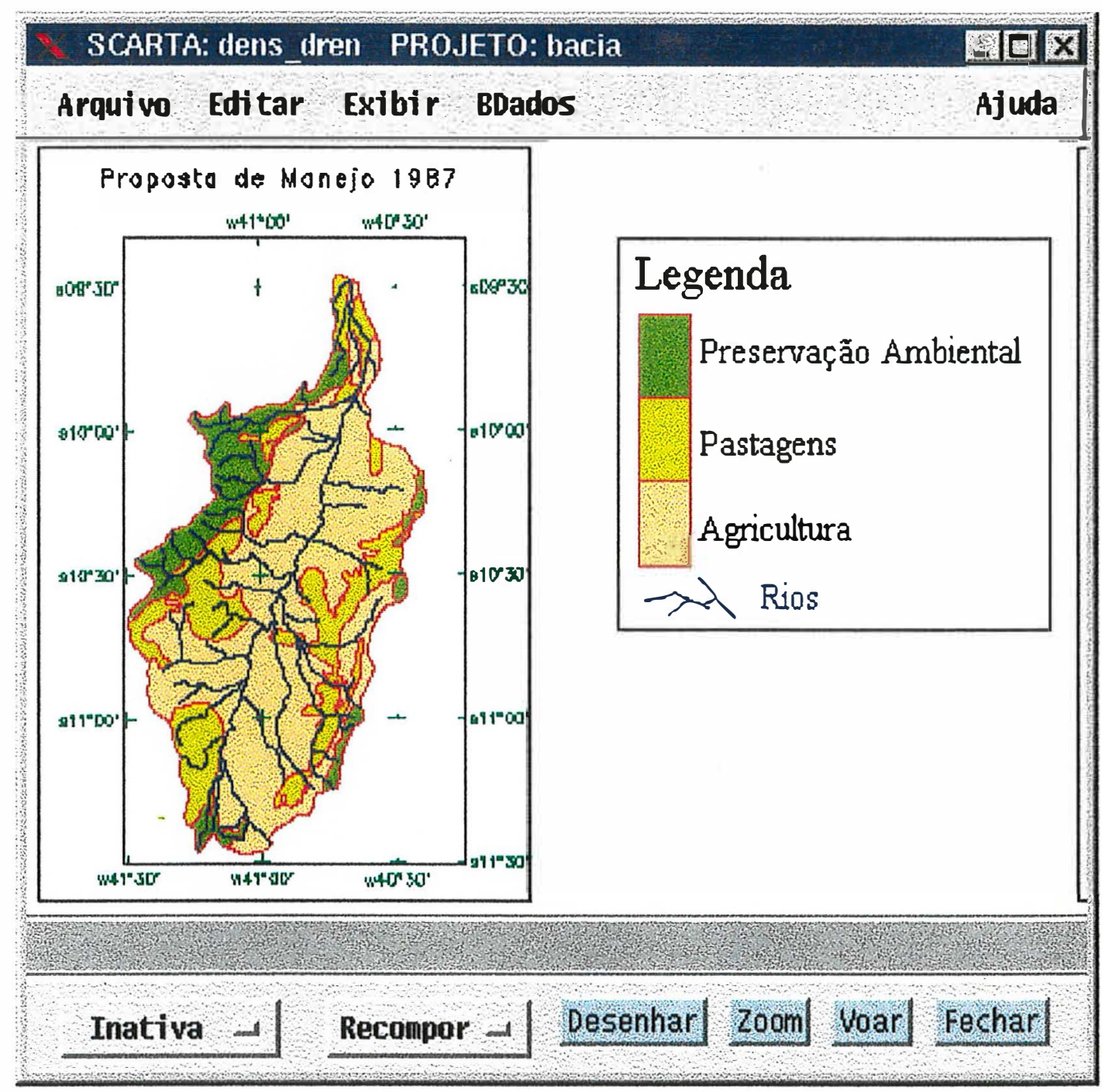

Figura 20 - Plano de Informação do zoneamento agroecológico proposto pela SEPLANTEC (BAHIA, 1986).

A quantificação das categorias do zoneamento agroclimático remete a $59,33 \%$ da área para a agricultura, $25,21 \%$ para pastagens e 15,47 $\%$ para reserva ecológica, ou da biodiversidade. 
A importância que assume esse plano de informação reside na determinação, por área, da utilização mais provável e que caracteriza um processo de domínio territorial com vistas ao desenvolvimento econômico regional. Isso implica que, no modelo de determinação do potencial de salinização das terras pelos cultivos, as áreas consideradas principais para a inserção serão as de utilização agrícola, dominantes neste plano de informação. As áreas de pastagens e de reserva natural não serão consideradas como áreas de inserção no modelo.

Outros planos de informação foram gerados, principalmente para determinação das zonas hidrologicamente homogêneas, conforme procedimento estabelecido pela SEPLANTEC (BAHIA, 1986). A Tabela 3 apresenta um resumo de todos os planos de informação gerados com o nome de suas respectivas categorias, além de uma descrição e uma definição à qual pertence cada categoria. Dessa forma procuro-se ter um banco de dados georreferenciados da bacia do rio Salitre. Cabe salientar também que alguns planos de informação, ali presentes, foram gerados pela aplicação do modelo de Prendergast utilizando-se a LEGAL, os quais serão estudado nas próximas seções.

\subsubsection{Esquema conceitual.}

A digitalização dos dados para a criação dos diferentes planos de informação, culmina com a formação do esquema conceitual. Ele representa o desenvolvimento do algoritmo de interpolação e de cruzamento de dados, para a aplicação em um modelo, que permitirá uma resposta 
baseada em simulação matemática das interações entre as variáveis ambientais.

TABELA 3 - Banco de dados georreferenciados da bacia do rio Salitre.

\begin{tabular}{|c|c|c|}
\hline Categorias & Planos de Informação & Modelo e Descrição \\
\hline Solo & Classes & Temático - classes de solos da bacia \\
\hline Cobertura Vegetal & cob_veget_87 & $\begin{array}{l}\text { Temático - cobertura vegetal da bacia em } \\
1987\end{array}$ \\
\hline \multirow[t]{2}{*}{ Isoietas e Declives } & Isoietas & Numérico - precipitação pluviométrica \\
\hline & Evaporação & $\begin{array}{l}\text { Numérico - amostras de evaporação de } \\
\text { tanque }\end{array}$ \\
\hline Défict Hidrico & Defict_hidrico & $\begin{array}{l}\text { Numérico - grade retangular do defict } \\
\text { hídrico }\end{array}$ \\
\hline $\begin{array}{l}\text { Zoneamento } \\
\text { Salinidade }\end{array}$ & Sal_hidric & $\begin{array}{l}\text { Temático - teor de sólidos dissolvidos das } \\
\text { águas }\end{array}$ \\
\hline Permeabilidade & Permeabilidade & Temático - permeabilidade dos solos \\
\hline \multirow[t]{2}{*}{$\begin{array}{ll}\text { Suscetibilidade dos } \\
\text { Solos }\end{array}$} & Suscetib_solos87 & $\begin{array}{l}\text { Temático - classes de suscetibilidade aos } \\
\text { sais }\end{array}$ \\
\hline & Solo salinity & Temático - cnuzamento classes $\mathrm{x}$ sal hidric \\
\hline Manejo & Asilpas87 & Temático - proposta de manejo 1987 \\
\hline \multirow[t]{2}{*}{ Drenagem } & Hidrografia & Rede - rede hidrográfica da bacia \\
\hline & Hidrogrf 100 & Rede - rede hidrográfica no Baixo Salitre \\
\hline Geologia & Gelogia2 & Temático - formações geológicas da bacia \\
\hline Imagens AVHRR & AVHRR_jun92a_ml & $\begin{array}{l}\text { Imagem - AVHRR Baixo Salitre NDVI } \\
\text { jun/92 }\end{array}$ \\
\hline \multirow[t]{4}{*}{ Imagens Landsat TM } & Imagem TM3 baixo & Imagem - baixo salitre Landsat TM banda 3 \\
\hline & Imagem TM4 baixo & Imagem - baixo salitre Landsat TM banda 4 \\
\hline & Imagem TM5 baixo & Imagem - baixo salitre Landsat TM banda 5 \\
\hline & IVDN & Imagem - LEGAL NDVI TM3 x TM4 \\
\hline \multirow[t]{3}{*}{ Produção } & Prod_rel_LF10\% & \begin{tabular}{|llll}
$\begin{array}{l}\text { Temático - produção para LF } \\
\text { (LEGAL) }\end{array}$ & 10\% \\
\end{tabular} \\
\hline & \begin{tabular}{|l|} 
Prod rel LF5\% \\
\end{tabular} & Temático - produção para LF 5\%(LEGAL) \\
\hline & Prod rel LF1\% & Temático - produção para LF 1\% (LEGAL) \\
\hline \multirow[t]{2}{*}{ Climatologia } & Ep & Temático - dados de evaporação \\
\hline & $\mathbf{R}$ & \begin{tabular}{|l}
$\begin{array}{l}\text { Temático - dados de precipitação } \\
\text { pluviométrica }\end{array}$ \\
\end{tabular} \\
\hline
\end{tabular}

Os dados pertencentes a cada plano de informação formarão o conjunto dos valores para cada variável ambiental, fisiográfica ou climática. 
Utilizou-se como modelo de cruzamento dos dados, o proposto por Prendergast (1993) . Os planos de informação, obtidos como dados de resposta do modelo, compreendem a informação georreferenciada sobre a resposta produtiva de uma determinada cultura à aplicação de uma determinada lâmina de lixiviação, consideradas as variáveis ambientais necessárias ao modelo.

A Figura 21 apresenta o modelo conceitual do algoritmo, desenvolvido em Linguagem Espacial para Geoprocessamento Algébrico LEGAL - para a aplicação do modelo de Prendergast utilizando-se o SPRING.

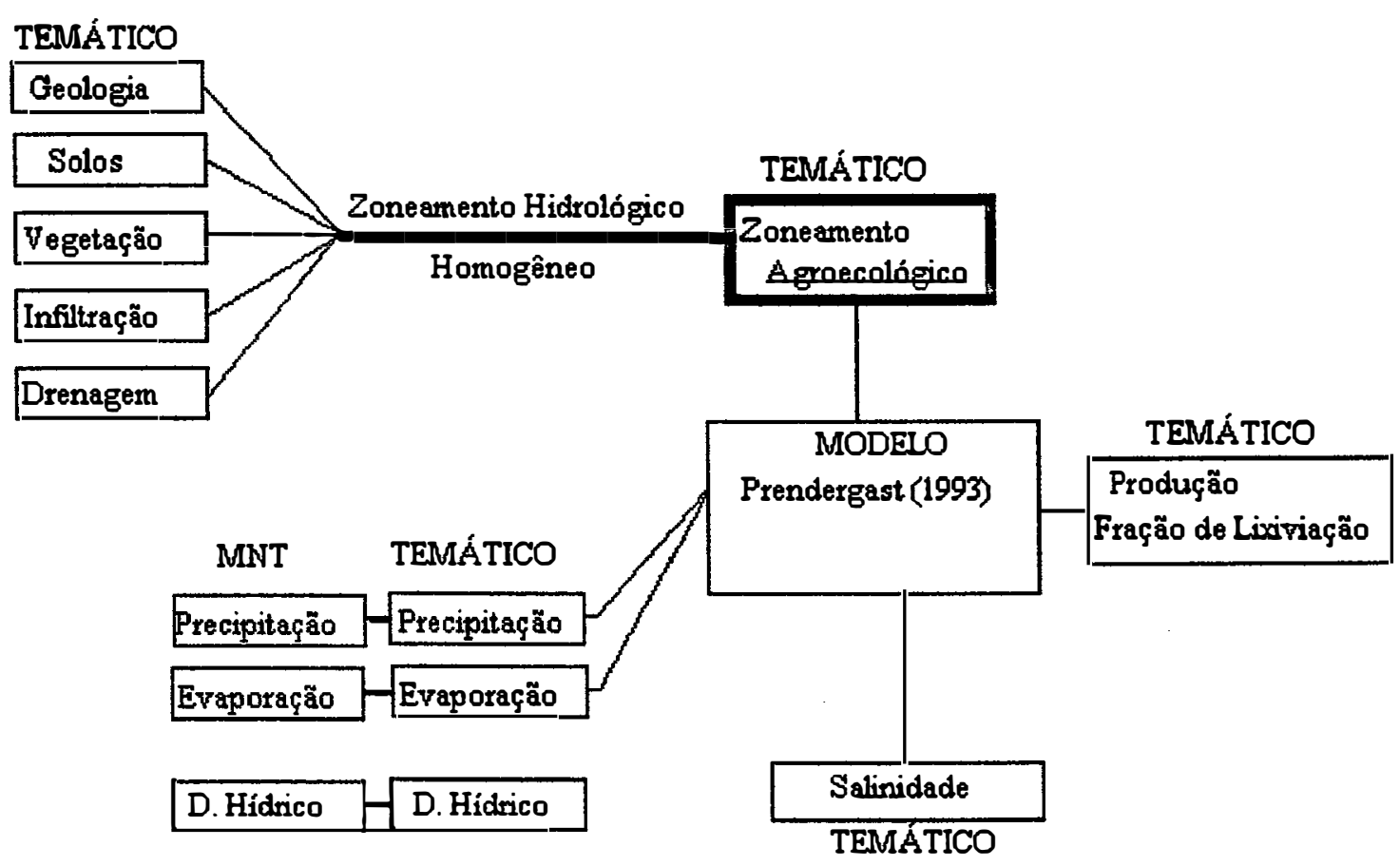

Figura 21 - Esquema conceitual para aplicação do modelo de Prendergast. 


\subsection{Utilizando a LEGAL para o modelo Prendergast.}

Este capítulo apresenta os procedimentos necessários para a realização de operações sobre dados dos tipos mapa temático, modelo numérico de terreno e imagem, implementados através de uma linguagem de consulta e de manipulação espacial, chamada de Linguagem Espacial para Geoprocessamento Algébrico - LEGAL -, ou módulo de análise algébrica do SPRING (INPE, 1997).

O que distingue um SIG de outros tipos de sistemas de informação são aquelas funções que possibilitam a realização de análises espaciais. Elas utilizam os atributos espaciais e não-espaciais das entidades gráficas, armazenadas na base de dados espaciais, buscando fazer simulações (modelos) sobre os fenômenos do mundo real, seus aspectos ou parâmetros.

As operações algébricas, em LEGAL, envolvem dados georeferenciados, representados sob a forma matricial ou vetorial. Permitem a realização dos procedimentos, sob a forma descritiva, onde dados e procedimentos são declarados e organizados segundo regras gramaticais, sob a forma de um programa, permitindo a modelagem de variadas aplicações em geoprocessamento.

Os Pis, caracterizados como geo-campos (Temático, Numérico, e Imagem), utilizam a representação matricial para operações algébricas, apesar de PI temático, por exemplo, poder ter a representação vetorial associada. Já os PIs cadastrais, representados por mapas de geoobjetos, trabalham somente com a representação vetorial, de modo que o 
operador sobre objetos, oferecido pelo LEGAL, a reclassificação por aributos, permite gerar a partir de um mapa cadastral, dados temáticos em representação vetorial (INPE, 1997).

Outra possibilidade para a utilização de dados vetoriais é gerar dados do modelo numérico (grade numérica matricial), com base na representação temática vetorial, segundo as classes representadas no PI temático, através de operações de reclassificação por atributos.

Um programa em LEGAL é constituído de sentenças (linhas de comando), estruturadas em três partes: declarações, instanciações e operações. A declaração define as variáveis de trabalho. Cada variável deve ser declarada explicitamente, isto é, deve fornecer um nome e associar-se a uma categoria no esquema conceitual. A instanciação recupera os dados já existentes no banco de dados, ou cria um novo PI. Este poderá, então, associar-se ao resultado de operações em LEGAL. A operação realiza os procedimentos relativos à álgebra de mapas (INPE, 1997).

Cada sentença, em LEGAL, pode envolver símbolos (por exemplo, "\{", "(", ";", ","), operadores (por exemplo, ‘+', ‘*’, ‘\&\&', '\|l' , '<c, '<=', '!='), palavras reservadas (por exemplo, Novo, Temático, Nome, Resx), nomes de variáveis e nomes de dados (PIs). Os nomes dos PIs, categoria e classes temáticas devem ser escritos entre aspas ("'). As palavras reservadas iniciam-se com maiúscula e não utilizam acentos (por exemplo, Tematico).

No desenvolvimento aqui proposto, a linguagem LEGAL foi utilizada com dois propósitos. Em primeiro lugar, para proporcionar a criação de planos de informação temáticos sobre a produção relativa dos cultivos, em relação à fração de lixiviação aplicada no manejo da irrigação; 
consideram-se as variáveis ambientais necessárias ao modelo Prendergast. Num segundo momento, a linguagem permitiu estabelecer o cruzamento e a álgebra de imagens Landsat, em diferentes bandas, com o objetivo de utilizando-se índices de vegetação, quantificar o processo atual de degradação e as perspectivas futuras. Dessa forma, foram criados basicamente dois algoritmos em LEGAL para os dois objetivos acima propostos, descritos a seguir.

De acordo com o modelo acima exposto e com os dados georreferenciados dos diversos planos de informação da bacia, foi estabelecido um cruzamento entre planos temáticos que caracterizassem as variáveis ambientais do modelo de Prendergast.

Assim, foi estabelecida a hipótese inicial de que para dados históricos médios de precipitação pluviométrica e de evaporação poder-seia regionalizar a informação sobre quais as terras mais propícias à atividade agrícola; procurou-se determinar a redução provável da produção agrícola se, uma determinada fração de lixiviação fosse aplicada ao processo produtivo.

Foram consideradas as frações de lixiviação de $10 \%, 5 \% \mathrm{e}$ $1 \%$, uma vez que a reduzida demanda hídrica não permite elevadas frações de lixiviação, sob pena de escassez de recursos e aumento da demanda de conflitos pelo uso da água. Além disso, estabeleceu-se, como critério, a utilização racional das águas das chuvas no processo de lixiviação de sais, ou seja, toda a água de chuva devia ser utilizada para tal fim.

Com base nos dados georreferenciados do teor de sólidos totais das águas superficiais e subterrâneas da bacia, determinaram-se as condutividades elétricas prováveis regionalizadas das águas de irrigação, 
conforme descrito anteriormente, para a criação do plano de informação sobre o zoneamento da salinidade.

Os fatores relativos à produção, ou seja, os coeficientes de cultivo, os fatores de produção de cultivos e a tolerância do cultivo agrícola à salinidade, para fins de exemplificação, foram utilizados aqueles disponíveis para tomate (Lycopersicon esculentum), um cultivo agroindustrial muito desenvolvido na região do Médio São Francisco. A regionalização pode ser efetuada da mesma forma para outros cultivos, desde que se tenha dados disponíveis. Para tomate, os coeficientes utilizados foram $K=1,03 ; \mathrm{Kc}=0,7 ; \mathrm{Ky}=1,05, A=2,50$ e $B=9,90$.

Dois outros fatores, necessários à análise espacial, que merecem uma discussão mais detalhada são a runoff e a salinidade da água das chuvas. Ambos são espacialmente distribuídos e deveriam ser determinados através de trabalhos de campo. Entretanto, como a bacia apresenta a superfície mais propícia à prática agrícola bastante homogênea e plana, e estes dados não estão disponíveis, foi generalizada a informação de $25 \%$ da chuva incidente (Villela \& Mattos, 1975). Para o segundo fator, a salinidade das águas das chuvas, foi utilizado o valor de $0,08 \mathrm{dS} / \mathrm{m}$, empregado para as condições australianas. Optou-se por usar este valor devido à completa falta de dados de pesquisa disponíveis sobre o assunto, para a região Nordeste do Brasil (Holanda \& Amorim, 1997).

Foram utilizadas a lógica boolena e as operações matemáticas pertencentes à LEGAL, de forma que os planos de informação Ep (Evaporação) e P (Precipitação) da categoria Climatologia, asilpas87 da categoria Manejo e sal_hidric da categoria Zoneam_da_Salinidade, fossem cruzados para se obter os planos de informação Prod_rel_LF10\%, 
Prod_rel_LF5\% e Prod_rel_LF1\%, da categoria Produção. Eles caracterizam a regionalização das respostas produtivas de tomate à aplicação de lâminas de lixiviação de $10 \%, 5 \%$ e $1 \%$, respectivamente. No Anexo tem-se a descrição detalhada do programa em LEGAL.

Para ilustrar o procedimento utilizado, com a linguagem LEGAL para trabalhar com imagens em sensoriamento remoto, foi feito um programa de cálculo do índice de vegetação, a partir das bandas 3 e 4 do satélite Landsat, computado a partir da fórmula a seguir:

$$
\text { IV }=(\text { banda } 4 \text { - banda3) } /(\text { banda } 4 \text { + banda3) }
$$

Para trabalhar com imagens Landsat, bandas 3 e 4, e gerar uma nova banda de índice de vegetação, temos que declará-las através de variáveis, com os respectivos nomes de "banda3", "banda4" e "ivdn". Essas variáveis devem pertencer a uma categoria Imagem, por exemplo "Landsat", como nos exemplos:

Imagem banda3 ("Imagem_TM");

Imagem banda4 ("Imagem_TM");

Imagem ivdn ("Imagem_TM").

O próximo passo é fazer a instanciação, isto é, recuperar os PIs correspondentes à imagem Landsat, banda 3 e banda 4, (cujos nomes no projeto ativo são "TM3" e "TM4"), utilizando-se o comando Recupere:

$$
\begin{aligned}
& \text { banda } 3=\text { Recupere }(\text { Nome="baixo_TM3"); } \\
& \text { banda } 4=\text { Recupere }(\text { Nome }=" \text { "baixo_TM4"); }
\end{aligned}
$$

Para criar um novo PI, com o resultado da operação de cálculo de índice de vegetação, utiliza-se o comando Novo, onde se deve indicar o nome da variável, o nome que será utilizado pelo banco de dados e a resolução da imagem resultante: 


$$
\operatorname{ivdn}=\text { Novo }(\text { Nome }=\text { "IVDN", } \operatorname{ResX}=30, \operatorname{Res} Y=30) \text {; }
$$

Para executar a operação entre as bandas e criar uma imagem correspondente ao índice de vegetação, aplique a fórmula:

$$
\operatorname{ivdn}=127 *(\text { banda } 4 \text { - banda } 3) /(\text { banda } 4+\text { banda })+128 \text {; }
$$

Para não saturar a imagem resultante, multiplicamos o resultado por $127 \mathrm{e}$ somamos 128, para que o valor resultante fique entre 0 e 255 .

O programa completo em LEGAL será o seguinte:

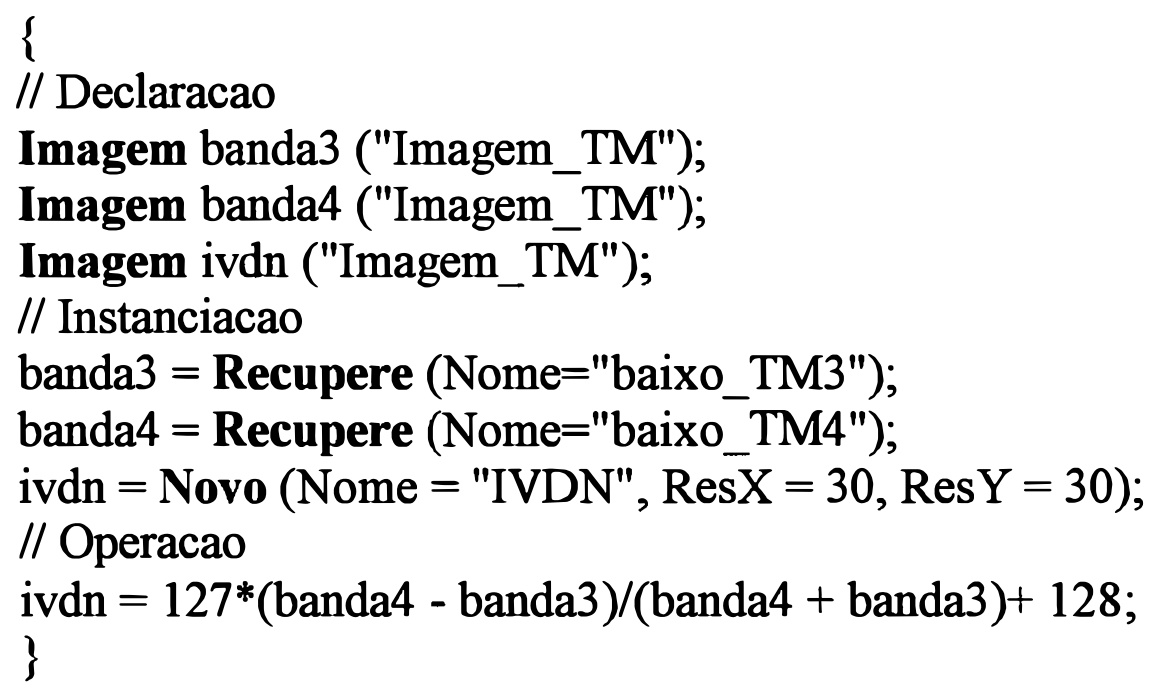

Observe que um programa está sempre contido entre dois colchetes e que comandos entre duas barras são comentários. 


\section{RESULTADOS E DISCUSSÃO}

Os resultados da aplicação e da análise de um modelo de simulação residem em novas hipóteses de trabalho, no intuito de descrever a realidade atual e propor ações em relação a ela, de forma a reduzir o impacto da degradação no futuro.

Basicamente, a região do Médio São Francisco é produtora das culturas de algodão (Gossypium hirsutum L.), cana-de-açucar (Saccharum offcinarum L.), cebola (Allium cepa L.), feijão (Phaseolus vulgaris L.), melancia (Citrillus vulgaris Schrad.), melão (Cucumis melo L.), milho (Zea mays L.), tomate (Lycopersicon esculentum Mill.) e uva (Vitis vinifera $\mathrm{L}$.).

A Tabela 5 apresenta, de forma resumida os coeficientes específicos, relacionados aos cultivos, e que podem ser utilizados na equação de Prendergast, para a determinação da produção relativa da cultura a uma determinada fração de lixiviação aplicada. Está sendo considerado o valor de Kc da fase de maior exigência hídrica da cultura; já o valor de Ky é representativo para todo o período de produção.

$\mathrm{O}$ modelo pode ser aplicado indistintamente, para qualquer fase de desenvolvimento da cultura. $O$ estudo da caracterização agroclimática, aplicada às diferentes fases, pode ser de enorme validade na 
identificação por sensoriamento remoto das fases mais críticas, e no comportamento dos cultivos sob a condição regionalizada.

A aplicação da condição mais crítica generaliza a informação conceitual dos parâmetros de produção relacionados, principalmente, ao coeficiente de cultivo, mas esse procedimento permite, pelo menos, estabelecer as máximas necessidades hídricas e as necessidades de lixiviação a elas associadas. Em outras fases, um sistema compensatório entre as necessidades hídricas da cultura e a lixiviação de sais do solo pode ser aplicado, enquanto, na fase de maior exigência hídrica, esse sistema compensatório fica reduzido a um valor mínimo, estabelecido pelo modelo de Prendergast.

Tabela 5 - Coeficientes médios aplicados para os cultivos mais importantes da região do Médio São Francisco.

\begin{tabular}{ccccc}
\hline Cultura & Kc & Ky & A & B \\
\hline algodão (Gossypium hirsutum L.) & 1,10 & 0,85 & 7,7 & 5,2 \\
cana (Saccharum offcinarum L.) & 1,20 & 1,20 & 1,7 & 5,9 \\
cebola (Allium cepa L.) & 1,10 & 1,10 & 1,2 & 16,0 \\
feijão (Phaseolus vulgaris L.) & 1,20 & 1,15 & 1,0 & 19,0 \\
melancia (Citrillus vulgaris Schrad.) & 1,05 & 1,10 & 2,5 & 13,0 \\
melão (Cucumis melo L.) & 1,05 & 1,10 & 2,5 & 13,4 \\
milho (Zea mays L.) & 1,20 & 1,25 & 1,7 & 12,0 \\
tomate (Lycopersicon esculentum Mill.) & 1,25 & 1,05 & 2,5 & 9,9 \\
uva (Vitis vinifera, L.). & 0,90 & 0,85 & 1,5 & 9,6 \\
\hline
\end{tabular}


Dessa forma, pode-se aplicar o modelo para qualquer um dos cultivos acima, no intuito de regionalizar tanto as necessidades para as respostas produtivas, quanto as necessidades hídricas para a lixiviação de sais. Para fins de exemplificação do método que este trabalho apresenta, foi escolheu-se o cultivo do tomate como modelo de simulação, para a análise da utilização de água por um determinado cultivo, de forma a racionalizar a recuperação dos solos afetados por sais.

\subsection{Exemplo de resposta produtiva para a cultura do tomate.}

A Figura 22 mostra a resposta produtiva provável do cultivo de tomate utilizando-se uma lâmina de lixiviação de $1 \%$ em toda a bacia hidrográfica.

A situação apresentada na Figura 22 caracteriza uma condição de escassez de recursos hídricos para a produção da cultura, de forma que a água aplicada é utilizada quase somente para a produção agrícola, sem respeitar a variável ambiental de tolerância da cultura aos sais presentes na água de irrigação. O que se observa como resposta, é uma grande área com uma produção no intervalo entre 40 e $20 \%$, ou seja, a produção provável de tomate, na área agricultável na bacia do rio Salitre, não ultrapassará $40 \%$ da produção máxima possível, se uma fração de lixiviação de $1 \%$ for adotada na prática da irrigação, sob regime dependente de chuvas. 


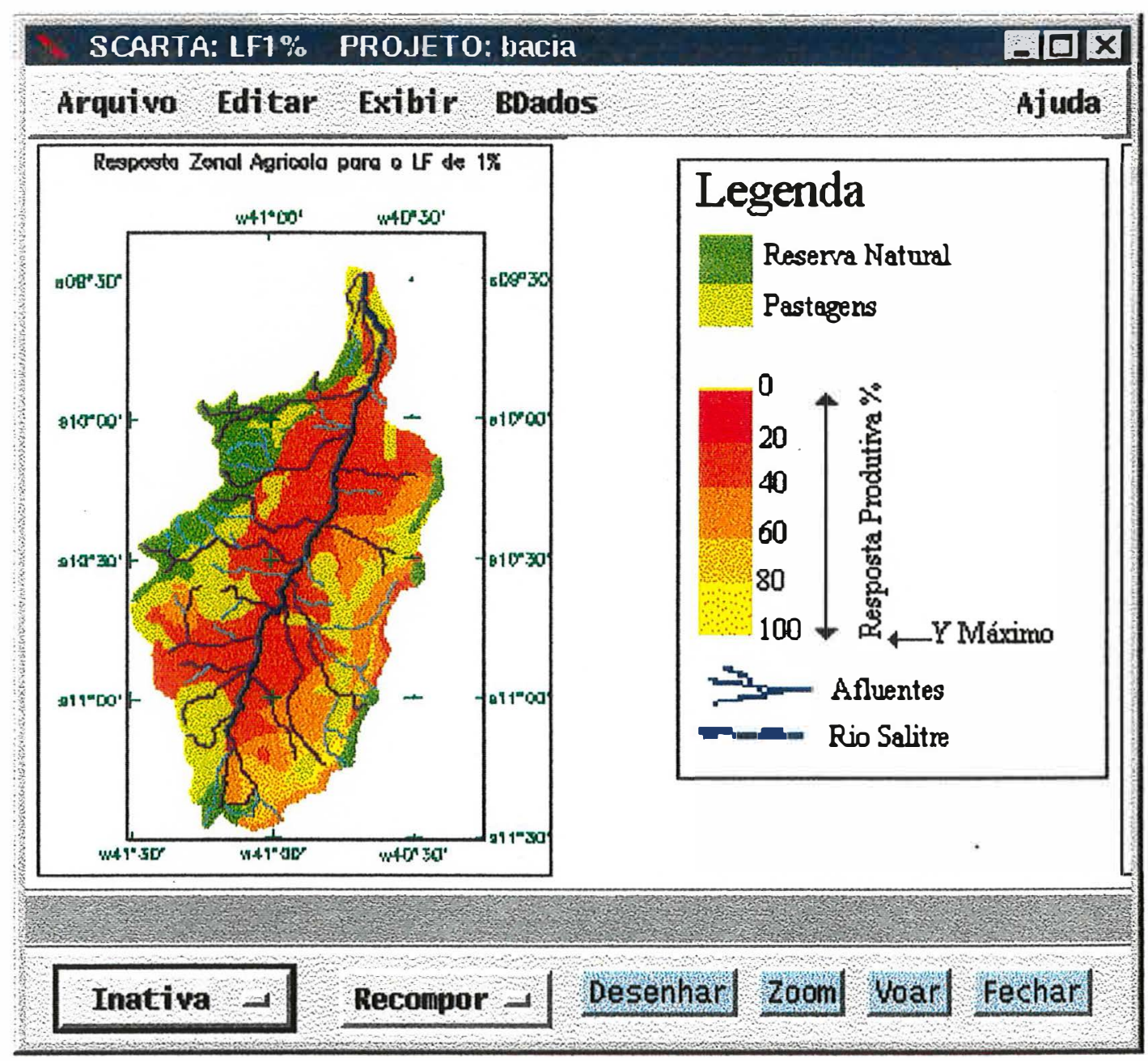

Figura 22 - Zoneamento da resposta produtiva para uma fração de lixiviação de $1 \%$.

A ravés dessa observação pode-se estabelecer uma nova hipótese de que, havendo escassez hídrica, os recursos produtivos concorrerão para a salinização das terras, se não se tomarem medidas de controle da demanda hídrica, para que as frações de lixiviação necessárias ao processo produtivo sejam aplicadas. Entretanto qual deve ser a fração de lixiviação a aplicar, para permitir uma resposta produtiva adequada às variáveis ambientais ali inseridas? 
As Figuras 23 e 24 apresentam a resposta provável para o cultivo de tomate utilizando-se uma lâmina de lixiviação de 5\% e 10\%, respectivamente.

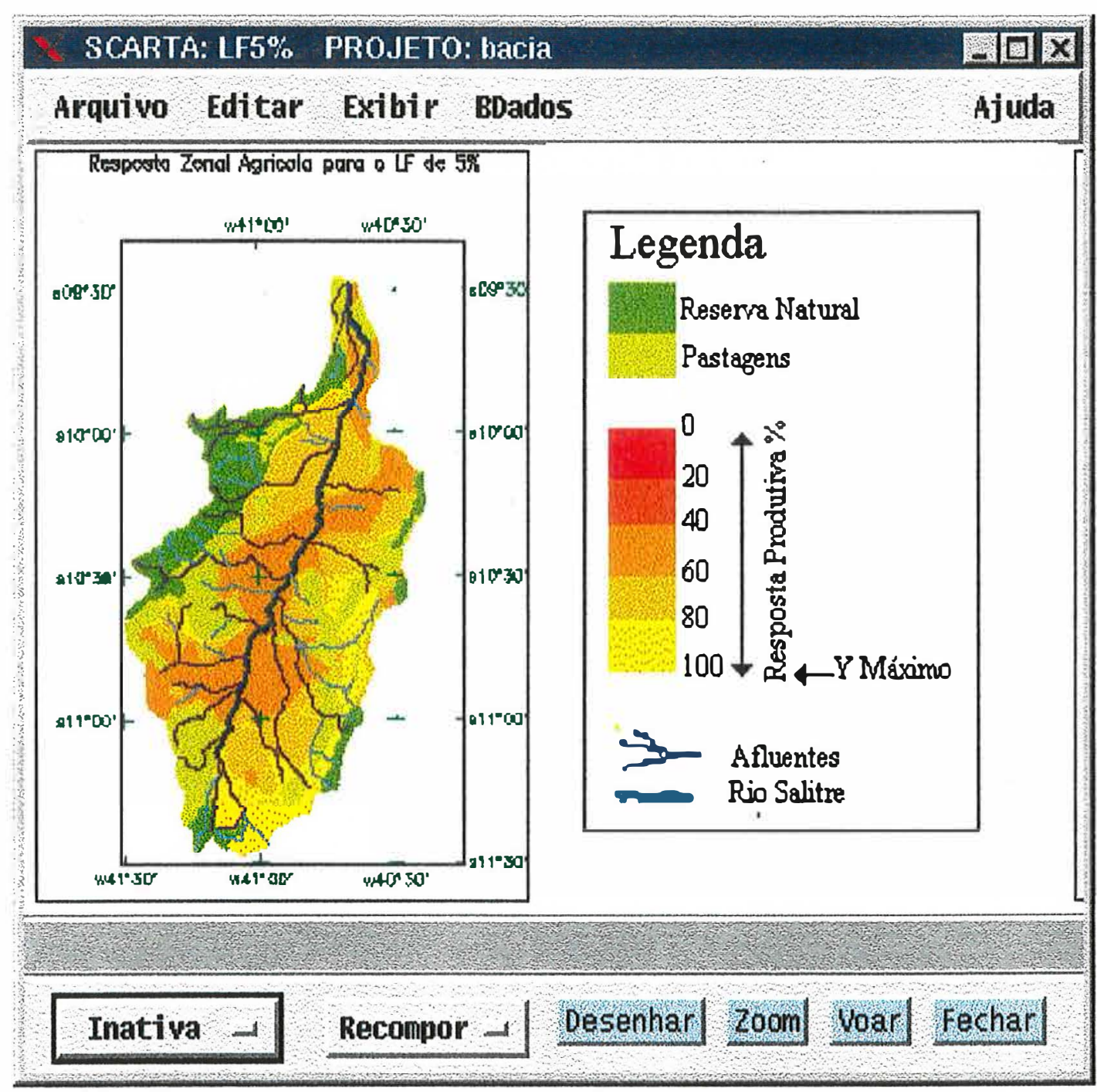

Figura 23 - Zoneamento da resposta produtiva para uma fração de lixiviação de $5 \%$.

Observa-se, na Figura 23, o aumento significativo da resposta de produção, para a faixa de 80 a 40\%, nas áreas agricultáveis. Nesse caso, 
já se permite evidenciar a importância da condição microclimática e da qualidade da água de irrigação para a regionalização da resposta de produção, uma vez que as variações de 80 a $60 \%$ e de 60 a $40 \%$ são devidas, principalmente, a tais variáveis, uma vez que elas estão sendo mantidas constantes.

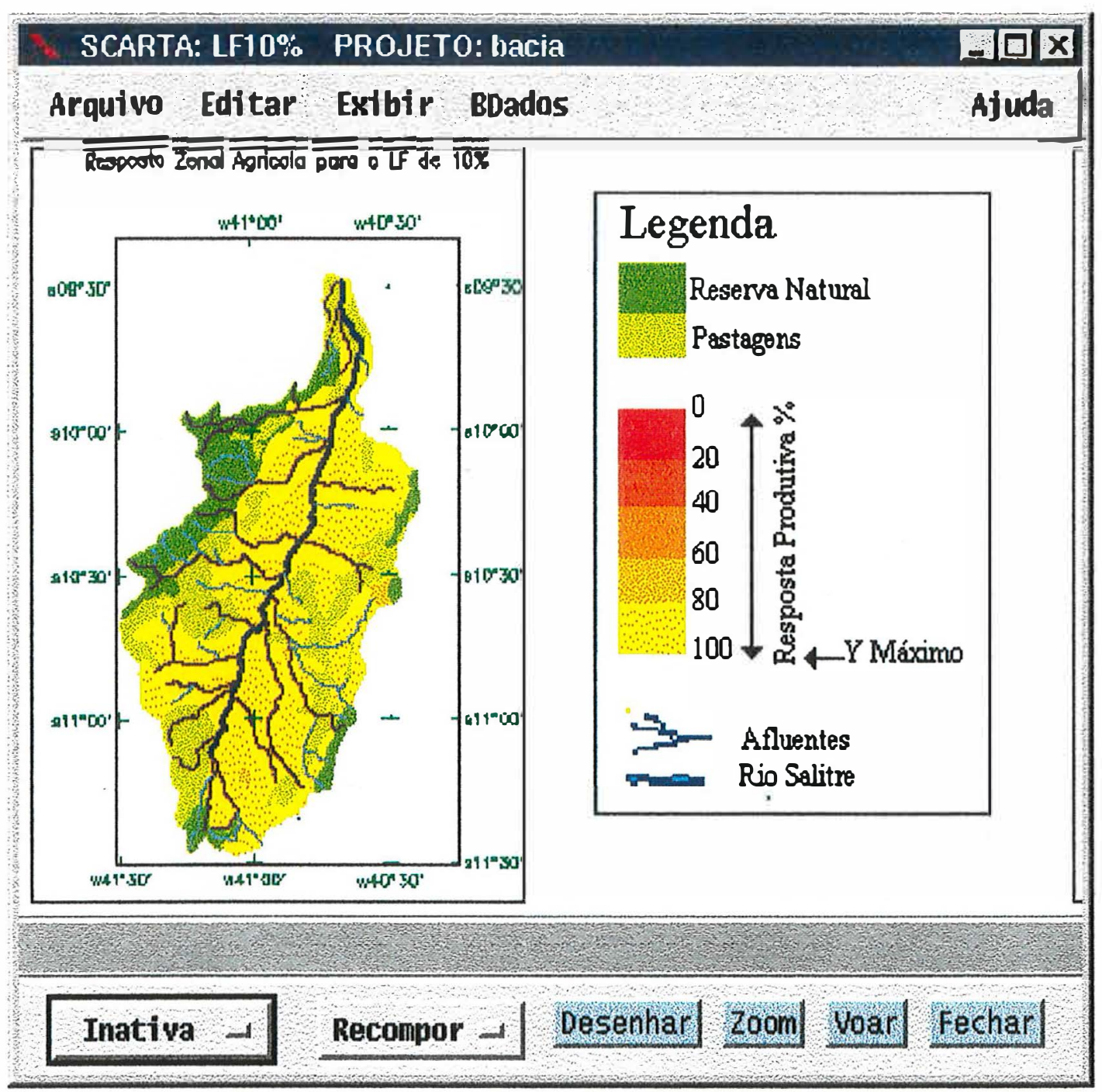

Figura 24 - Zoneamento da resposta produtiva para uma fração de lixiviação de $10 \%$. 
Considerando uma fração de lixiviação de $10 \%$, o aumento da resposta produtiva para 100 a $80 \%$ é evidente; e nesse caso, o fator de sensibilidade não é mais devido às variáveis climáticas, mas, sim, à qualidade da água de irrigação, como fator limitante à produção da cultura, já que a suscetibilidade forte evidenciada caracteriza regiões de águas subterrâneas e superficiais com elevados teores de sais.

Nesse caso, o modelo, aplicado às condições estabelecidas pelas variáveis ambientais presentes na Bacia, permitiu identificar regiões onde a resposta produtiva poderia ser afetada por uma determinada prática agrícola inadequada, estabelecendo limites da utilização da água como fator de produção para aquela condição específica.

4.2. Utilização de técnicas em sensoriamento remoto para quantificação do processo de degradação das terras.

Uma vez que pouco se conhece sobre os dados de sensoriamento remoto e que não é possível definir as classes de pixel com segurança, optou-se por uma classificação não supervisionada da região do Baixo Salitre, próximo à sua foz, onde se concentram os maiores projetos de agricultura imigada, e, por conseguinte, a maior suscetibilidade das terras ao problema de salinização.

Com este trabalho, procura-se estabelecer uma aproximação entre o valor do pixel relativo e uma determinada caracterização, relacionada 
ao problema da degradação das terras pela prática inadequada da irrigação para diferentes cultivos.

As amostras foram selecionadas com base na homogeneidade das áreas que caracterizam os diferentes cenários. Como essas variações não são muito significativas, é possível identificar claramente, nas imagens de satélite, diferentes regiões de abrangência num mesmo cenário. Pode-se observar a abrangência dos pixels, para cada classe nas Figuras 25, 26, 27 e 28 , respectivamente.

Esse setor da bacia, dadas as condições de extrema pobreza e das técnicas rudimentares aplicadas a atividade agropecuária, caracteriza-se por uma estrutura fundiária marcada pelo grande número de minifúndios. A classificação aplicada reflete-se no agrupamento das classes em formas pontuais, espalhadas por todo o setor.

Na classificação, foi utilizada a banda 3 do sensor Landsat TM e imagens do ano de 1987. Identificaram-se áreas de exposição de solo características de processos pontuais de abandono, devido ao problema da salinização, áreas de irrigação, de pastagens e de vegetação natural esparsa, com forte tendência à degradação e áreas de vegetação natural, onde a ação antrópica ainda não se fez evidente. A cada uma dessas classes, foram associadas a suscetibilidade forte, a moderada e a ligeira, respectivamente, além de rios, riachos, lagos e lagoas.

O SPRING realiza a classificação de forma automática. A Figura 29 é o resultado da utilização das amostras, acima determinadas, para a formação de um mapa de ocorrência de processos degradativos e de suscetibilidade a eles, na região do baixo Salitre. 


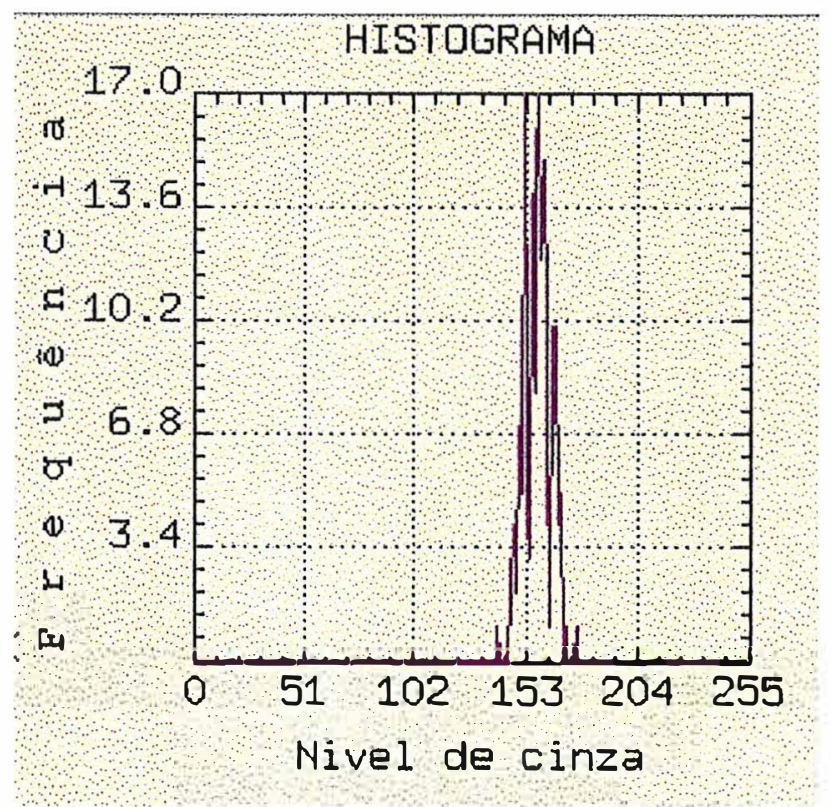

Figura 25- Frequência de ocorrência dos pixels representativos de uma amostra regionalizada, de suscetibilidade forte à ocorrência de um fenômeno de degradação.

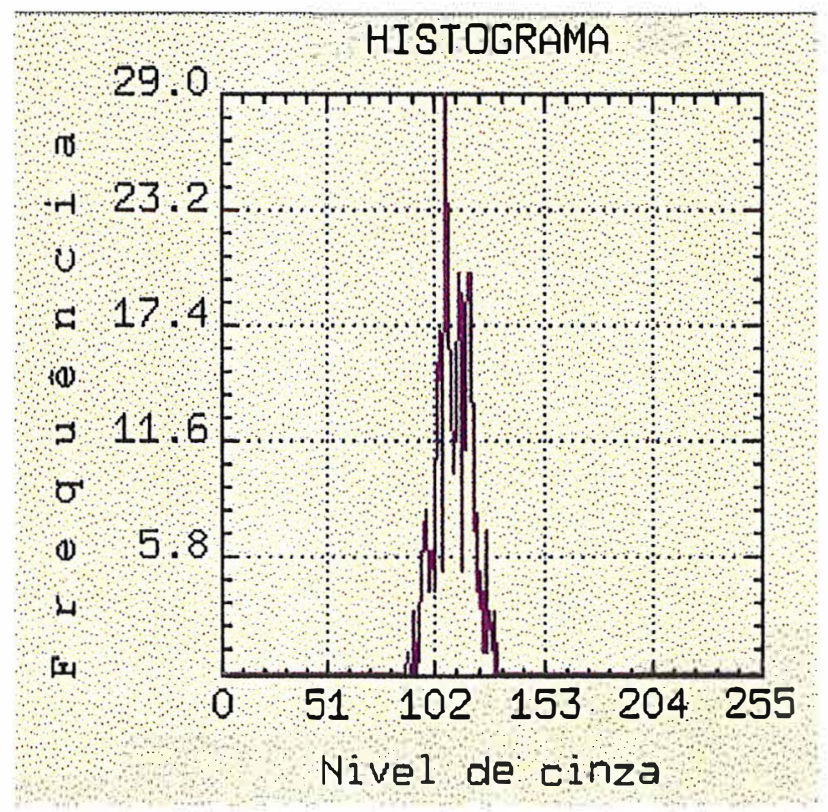

Figura 26- Frequência de ocorrência dos pixels representativos de uma amostra regionalizada, de suscetibilidade moderada à ocorrência de um fenômeno de degradação. 


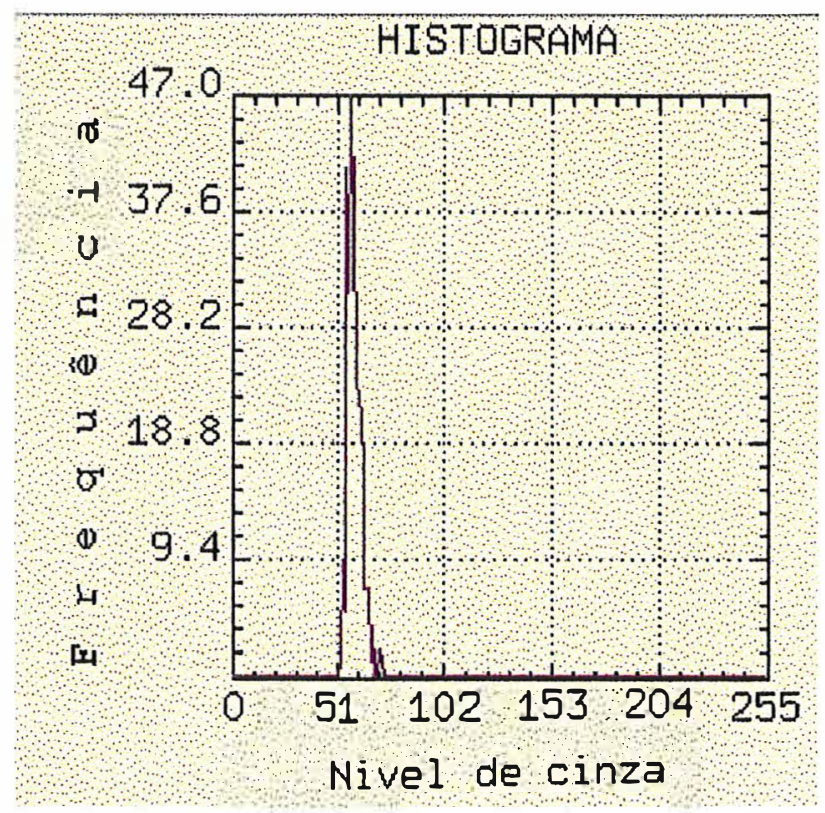

Figura 27- Frequência de ocorrência dos pixels representativos de uma amostra regionalizada, de sucetibilidade ligeira à ocorrência de um fenômeno de degradação.

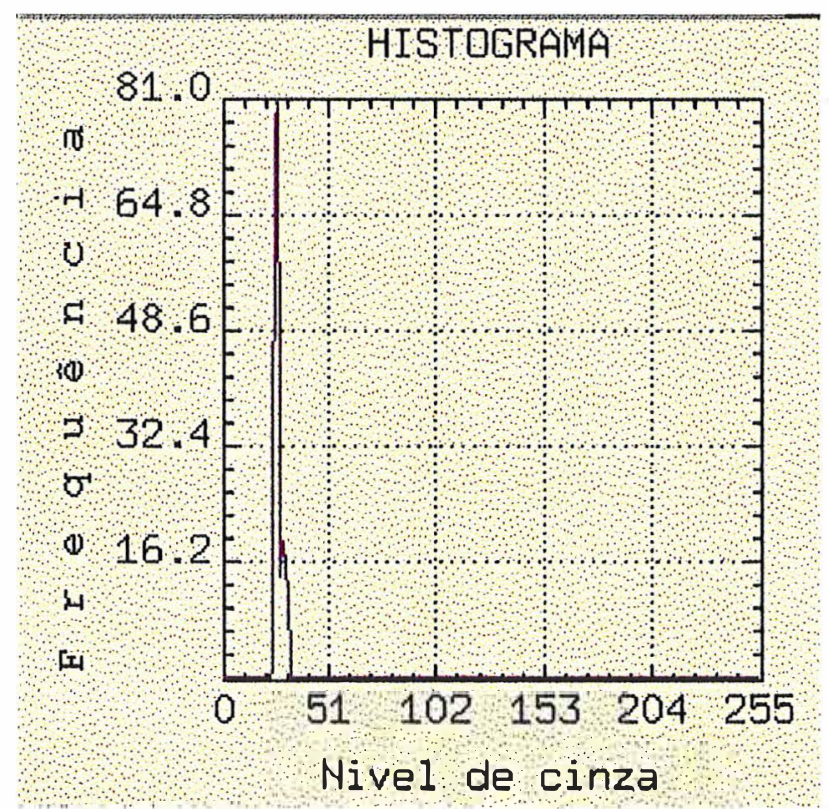

Figura 28- Frequência de ocorrência dos pixels representativos de uma amostra regionalizada dos rios, riachos, lagos e lagoas. 
A região do Baixo Salitre, foi escolhida por ser repositório de todas as água provenientes das regiões a montante da bacia. Outra característica decisiva é a presença de vários projetos de irrigação e a utlização de um sistema de transposição de águas do rio São Francisco, através de represas sucessivas. A intensa utilização agrícola, além das facilidades de acesso para a verificação de campo, permitem estabelecer, para esta região, resultados probatórios mais confiáveis. Tais observações de campo, associadas aos estudos de laboratório em sensoriamento remoto, permitiram essa classificação inicial para a análise do modelo de simulação.

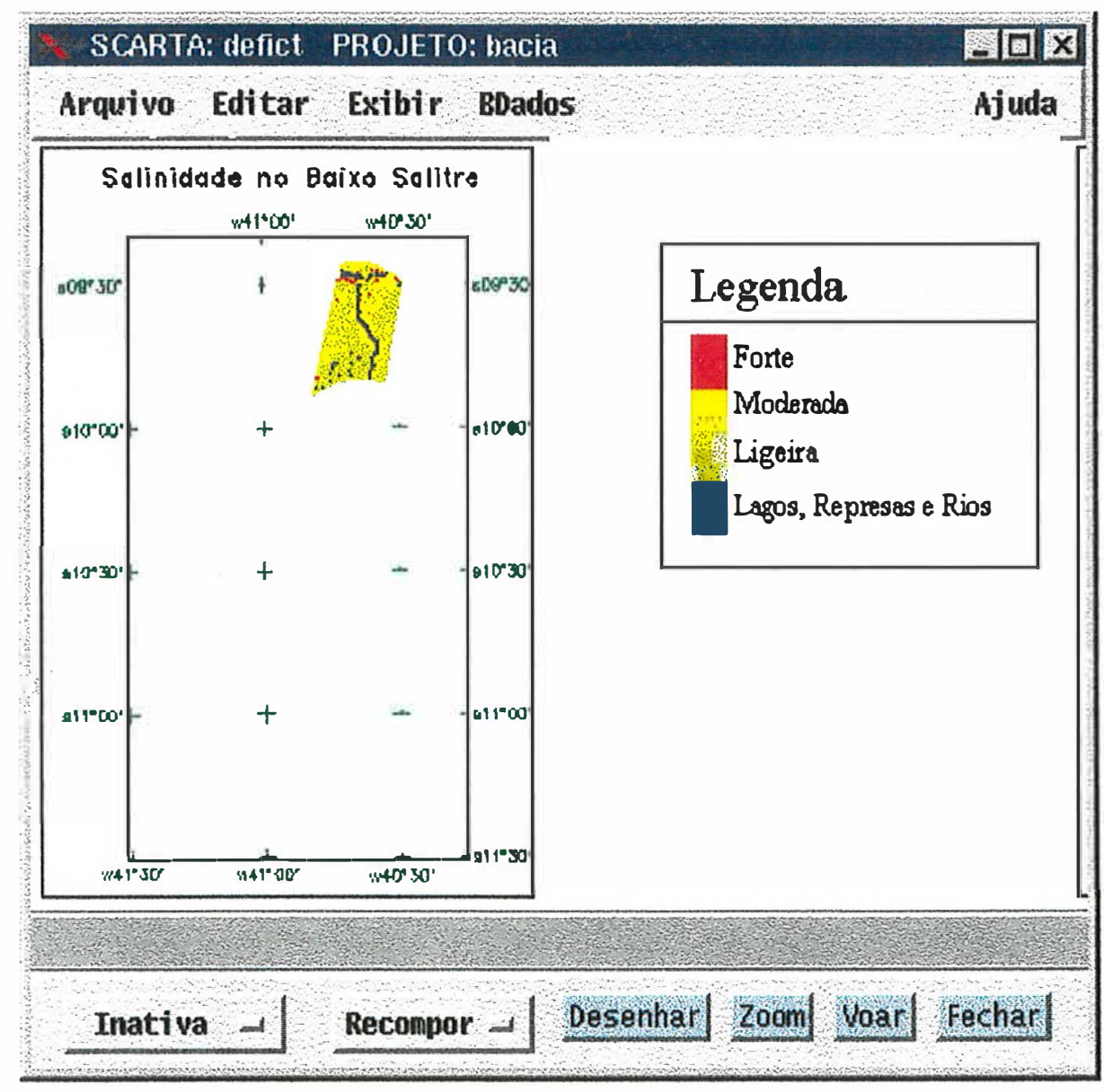

Figura 29 - Classificação não supervisionada das terras da região do baixo rio Salitre. 
O resultado da classificação mostrou que 47.540 ha de terras desta região da bacia encontravam-se com suscetibilidade forte e moderada, totalizando $40 \%$ da área estudada no Baixo Salitre; as áreas abandonadas totalizavam 2.526 ha, 2,14 \% da área estudada. Evidênciou-se que a totalidade desses 2.526 ha se encontra próxima aos rios Salitre e São Francisco, o que permite concluir que estão associadas a processos antrópicos ligados à prática da irrigação.

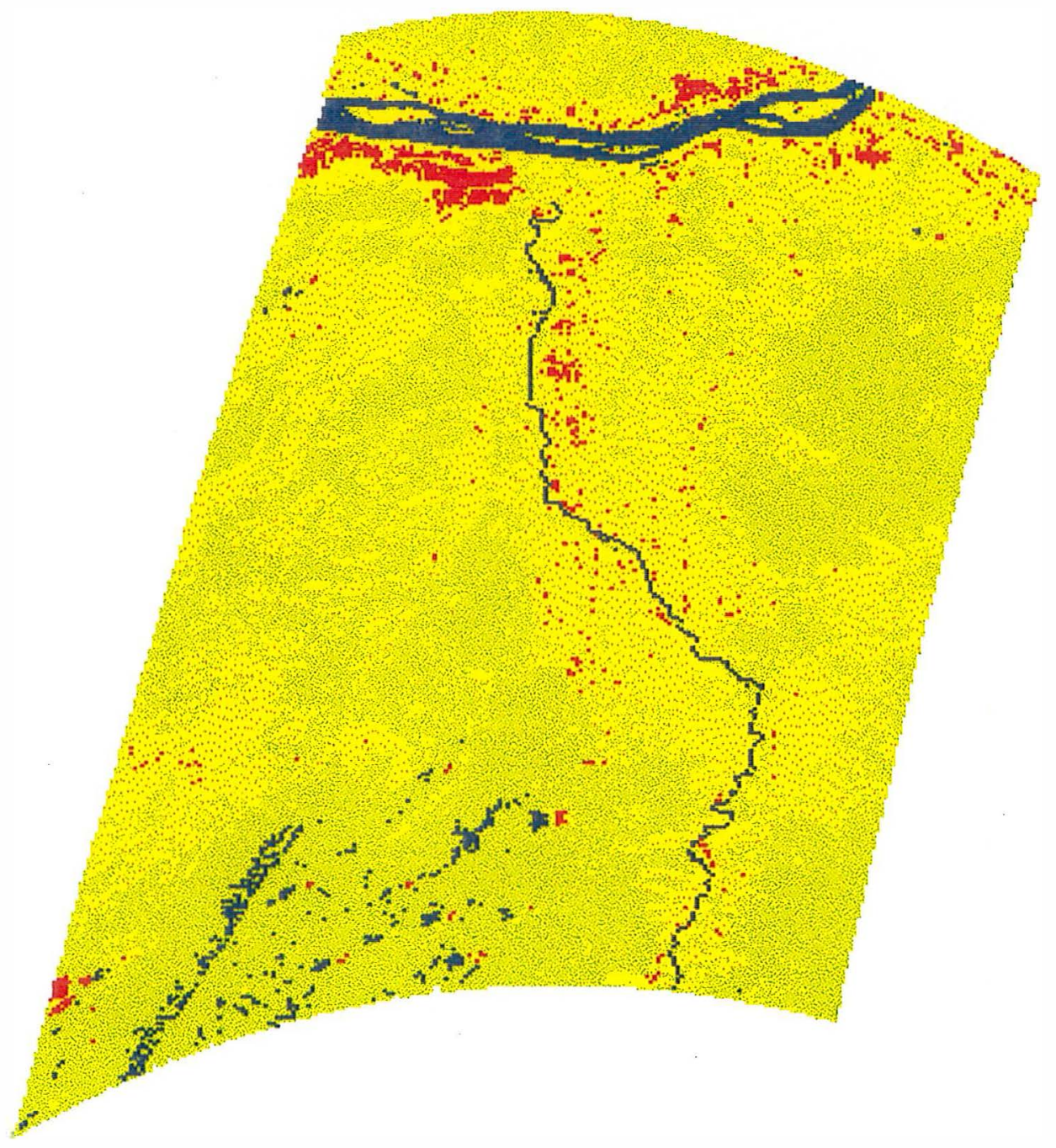

Figura 30 - Ampliação da classificação não supervisionada da região do baixo rio Salitre. 
A Figura 30 é uma ampliação da área detalhada na Figura 29. Podem-se observar na porção inferior esquerda da imagem, pontos na cor azul, que deveriam representar lagoas, rios ou riachos. Entretanto a maior parte deles é devida a sombras, resultantes do processo de aquisição da imagem, devido à existência da Serra do Mulato. O relevo dessa serra é escarpado, o que pode originar sombras na imagem, conforme a orientação do satélite e o ângulo de declinação do sol.

Um outro ponto importante a ser destacado na imagem é a impossibilidade de se diferenciar as áreas de suscetibiidade forte com as estradas. Os resultados mostram que, semelhantemente ao trabalho de Everit et al. (1984), e conforme a classificação de pixel proposta, não foi possível diferencia-las na imagem; uma classificação supervisionada pode aumentar esta diferença, através de um detalhamento que relacione o pixel ao cenário específico

Como pode ser visto na Figura 30, no ano de 1987 fazia-se necessário uma ação efetiva para controlar as áreas em processo degradativo na região do Baixo Salitre, principalmente, pela grande área amarela que representa uma atividade agrícola de suscetibilidade moderada, quanto pelas áreas vermelhas, que representam uma suscetibilidade forte. A atualização desse cenário pode permitir a comparação e a análise temporal, de forma a estabelecer como a atividade agrícola e a agricultura irrigada comprometeram as terras, em termos de salinização, nos últimos 10 anos. 


\section{CONCLUSÕES E RECOMENDAÇÕES.}

O modelo matemático utilizado em conjunto com a ferramenta SIG permite georreferenciar as informações da resposta produtiva dos cultivos, estabelecendo qual fator ou variável ambiental concorre de forma mais proeminente para o processo degradativo das terras, de forma a possibilitar uma informação mais precisa das áreas mais críticas.

$\mathrm{O}$ modelo não contempla o manejo da irrigação e da drenagem das terras, como práticas a serem empregadas na melhoria das condições de cultivo, de forma que a fração de lixiviação se reduza. Tais variáveis podem ser inseridas e, utilizando-se um método de otimização, pode-se chegar a frações de lixiviação mínimas, com produções máximas. Nesse caso, a LEGAL deve estar apta a estabelecer operações matemáticas de programação linear, no cruzamento destas informações e nas interações com outro softwares. Na versão 2.0.4 do SPRING o usuário não tem acesso ao código fonte para desenvolvimento desses algoritmos.

Dessa forma, o SPRING e a LEGAL são ferramentas úteis numa análise simulada da resposta produtiva dos cultivos, quando essas respostas identificam áreas de risco de salinização e de degradação, com o uso de técnicas de sensoriemento remoto e com a calibração dessas respostas para as diferentes culturas e seus ciclos. 
REFERÊNCIAS BIBLIOGRÁFICAS

ADDISCOTT, T.M. A simple computer model for leaching in structured soils. Journal of Soil Science, v.28, p.544-563, 1977.

BAGNOLD, R. A. The physics of blown sand and desert dunes. New York: William Morrow, 1942. 265 p.

BAHIA. Superintendência de Planejamento. Mapa de Aptidão das Terras do Estado da Bahia. Salvador: CEI/SEPLANTEC, 1978. Escala 1:1.000.000.

BAHIA. Secretaria de Planejamento Ciência e Tecnologia. Avaliação dos recursos hídricos das bacias hidrográficas do estado da bahia: bacia do rio Salitre. Salvador, 1986. 2v.

BARBOSA, M. A. Projeto àridas: recursos naturais e meio ambiente; desrtificação. Salvador: s.ed., 1994. 36p.

BEASLEY, D.B.; HUGGINS, L.F. ANSWERS (Areal Nonpoint Source Watershed Environmental Response Simulation): user's manual. Chicago: U.S. Environmental Protection Agency, 1982.102p. (Report, 905/9-82-001). 
BEASLEY, D.B.; HUGGINS, L.F.; MONKE, E.J. Modeling sediment yields for agricultural watersheds. Journal of Soil and Water Conservation, v.37, n.2, p.113-117, 1982.

BERNISTEIN, L.; FRANCOIS, L.E. Leaching requirement studies: sensitivity of alfafa to salinity of irrigation and drainage waters. Soil Science Society of America Proceedings, v.37, p.931-943, 1973.

BEVEN, K.J. Changing ideas in hydrology - the case of physically-based models. Journal of Hydrology, v.105, p.157-172, 1989.

BEVEN, K.J.; KIRKBY, M.J. A physically-based, variable contributing area model of basin hydrology. Hydrological Sciences Bulletin, v.24, p.4369, 1979.

BEVEN, K.J.; KIRKBY, M.J.; SCHOFIELD, N.; TAGG, A.F. Testing a physically-based flood forecasting model (TOPMODEL) for three U.K. catchments. Journal of Hydrology, v.69, p.119- 143, 1984.

BINLEY, A.; EGLY, J.; BEVEN, K.J. A physically-based model of heterogeneous hillslopes: 1. Runoff production, 2. Effective hydraulic conductivities. Water Resources Research, v.25, p.1219-1233, 1989.

BROWN, D.G.; BIAN, L.; WALSH, S.J. Response of a distributed watershed model to variations in input data aggregation levels. Computers and Geosciences, v.19, n.4, p.499-509, 1993. 
BUSACCA, A.J.; COOK, C.A.; MULLA, D.J. Comparing landscape-scale estimation of soil erosion in the Palouse using Cs-137 and RUSLE. Journal of Soil and Water Conservation, v.48, n.4, p.361- 367, 1993.

CÂMARA, G. Geoprocessamento para projetos ambientais. São José dos Campos: INPE, 1996. 130p. (Curso - Simpósio Brasileiro de Sensoriamento Remoto, 7., Salvador, 1996).

CÂMARA, G.; FREITAS, U.M.; SOUZA, R.C.M.; GARRIDO, J. SPRING: integrating remote sensing and GIS by object-oriented data modelling. Computers and Graphics, v. 15, n.6, July 1996.

CLEVERS, J. G. P. W. The derivation of a simplified reflectance model for the estimation of leaf area index. Remote Sensing of Environment, v.35, p.53-70, 1988.

COSTA-CABRAL, M.; BURGES, S.J. Digital elevation model networks (DEMON): a model of flow over hillslopes for computation of contributing and dispersal areas. Water Resources Research, v.30, n.6, p.1681-1692, 1994.

CRIPPEN, R.E. Calculating the vegetation index faster. Remote Sensing of Environment, v.34, p.71-73, 1990.

CRIST, E. P.; CICONE R. C. Application of the tasseled cap concept to simulated thematic mapper data. Photogrammetric Engineering and Remote Sensing, v.50, p.343-352, 1984. 
DALY, C.; NEILSON, R.P.; PHILLIPS, D.L. A statistical-topographic approach to modeling the distribution of precipitation in mountainous terrain. Journal of Applied Meteorology, v.33, n.1, p.140-158, 1994.

DE ROO, A.P.J., HAZELHOFF, L., AND BURROUGH, P.A. Soil erosion modelling using ANSWERS and geographical information systems. Earth Surface Processes and Landforms, v.14, p.517-532, 1989.

DOOREMBOS, J.; KASSAM, A.H. Yield response to water. Rome: FAO, 1979. (FAO. Irrigation and Drainage Paper, 33).

DREGNE, H. E. Desertification of arid lands. New York: Harwood Academic, 1983. 242p.

DREGNE, H. E; TUCKER C. J. Desert encroachment. Desertification Control Bulletin, v.16, p.16-19, 1988.

ENGEL, B.A.; SRINIVASAN, R.; AND REWERTS, C. A spatial decision support system for modeling and managing agricultural non-point source pollution. In: GOODCHILD, M.F.; PARKS, B.O.; STEYAERT, L.T. (Ed.) Environmental modeling with GIS. New York: Oxford University Press, 1993. p.231-237.

EVERITT, J.H.; ESCOBAR, D.E.; GERBERMANN, A.H.; ALANIZ, M.A. Detecting saline soils with video imagery. Photogrammetric Engineering and Remote Sensing, v.54, p.1283-1287, 1984. 
FAIRFIELD, J.; LEYMARIE, P. Drainage networks from grid digital elevation models. Water Resources Research, v.27, n.5, p.709-717, 1991.

FOSTER, G.R.; WISCHMEIER, W.H. Evaluating irregular slopes for soil loss prediction. Transactions of the American Society of Agricultural Engineers, v.17, n.2, p.305-309, 1974.

FOSTER, G.R.; LANE, L.J.; NOWLIN, J.D.; LAFLEN, J.M.; YOUNG, R.A. Estimating erosion and sediment yield on field-sized areas. Transactions of the American Society of Agricultural Engineers, v.24, n.5, p.1253-1262, 1981.

FOUSSEREAU, X.; HORNSBY, A.G.; BROWN, R.B. Accounting for variability within map units when linking a pesticide fate model to soil survey. Geoderma, v.60, p.257-276, 1993.

FRASER, R.H.; WARREN, M.V.; BARTEN, P.K. Comparative evaluation of land cover data sources for erosion prediction. Water Resources Bulletin, v.31, n.6, p.991-1000, 1995.

FREEMAN, G.T. Calculating catchment area with divergent flow based on a regular grid. Computers and Geosciences, v.17, n.3, p.413-422, 1991. 
FRERE, M. H.; ROSS, J. D.; LANE, L. J. The nutrient submodel. In: KNISEL, W.G. (Ed.) CREAMS: a field scale model for chemicals, runoff, and erosion from agricultural management systems. Washington: U.S. Department of Agriculture, Agricultural Research Service Conservation Research, 1980, p.65-87. (Report, 26).

FRYREAR, D. W.; STUBBENDIECK J.; MCCULLY W. G. Grass seedling response to wind and windblown sand. Crop Science, v.116, p.622-625, 1973.

GALLANT, J.C.; WILSON, J.P. TAPES-G: a grid-based terrain analysis program for the environmental sciences. Computers and Geosciences, v.22, n.4, 1996.

GARBRECHT, J.; MARTZ, L. Grid size dependency of parameters extracted from digital elevation models. Computers and Geosciences, v.20, n.1, p.85-87, 1994.

GATES, D. M.; KEEGAN, H. J.; SCHLETER, J. C.; WEIDNER, V. R. Spectral properties of plants. Applied Optics, n.4, p.11-20, 1965.

GLANZ, J. New soil erosion model erodes farmers' patience. Science, v.264, p.1661-1662, 1994.

GOODCHILD, M.F.; PARKS, B.O.; STEYAERT, L.T. Environmental modeling with GIS . New York: Oxford University Press, 1993. 
GOODCHILD, M.F.; STEYAERT, L.T.; PARKS, B.O.; CRANE, M.P.; JOHNSTON, C.A.; MAIDMENT, D.R.; GLENDINNING, S. (Ed.) GIS and environmental modeling: progress and research Issues. Fort Collins: GIS World, Inc., 1996. 486p.

GOODRICH, D.C., AND WOOLHISER, D.A. Catchment hydrology. In: INTERNATIONAL UNION OF GEODESY AND GEOPHYSICS. Reviews of Geophysics: 1987-1990. Washington, 1991. p.202-209.

GRAYSON, R.B.; MOORE, I.D.; McMAHON, T.A. Physically-based hyrdrologie modeline: II: Is the eoneept realistie? Water Resutrees Research, v.26, n.10, p.2659-2666, 1992.

GRIFFIN, M.L.; BEASLEY, D.B.; FLETCHER, J.J.; FOSTER, G.R. Estimating soil loss on topographically nonuniform field and farm units. Journal of Soil and Water Conservation, v.43, p.326-331, 1988.

HANKS, R. J. Model for predicting plant growth as influenced by evapotranspiration and soil water. Agronomy Journal, v.66, p.660-665, 1974.

HESSION, W.C., AND SHANHOLTZ, V.O. A geographic information system for targeting nonpoint - source agricultural pollution. Journal of Soil and Water Conservation v.43, n.3, p.264-266, 1988.

HILLEL, D. Introduction to soil physics. New York: Academic Press, 1982. $364 \mathrm{p}$. 
HOFFMAN, G. J.; VAN GENUCHTEN, M. T. H. Soil properties and eficient water use: water management for salinity control. In: TAYLOR, H.M.; JORDAN, W. R.; SINCLAIR T.R. (Ed.) Limitation to efficient water use in crop production. Madison: Am. Soc. Agron., Crop. Soc. Am., Soil Sci. Am., 1983. p.73-85.

HOLANDA, J. S.; AMORIM, J.R.A. Qualidade da Água para Irrigação. In: GHEYI, H.R.; QUEIROZ, J.E.; MEDEIROS, J. F. de (Ed.) Manejo e controle da salinidade na agricultura irrigada. Campina Grande: UFPB, 1997. p.137-165.

HOLÝ, M. Erosion and environment. Oxford : Pergamon Press, 1980. $225 \mathrm{p}$.

HORNBERGER, G.M.; BEVEN, K.J.; COSBY, B.J.; SAPPINGTON, D.E. Shenandoah watershed study: calibration of a topography-based, variable contributing area hydrological model to a small forested catchment. Water Resources Research, v.21, p.1841-1850, 1985.

HUETE, A. R. A soil-adjusted vegetation index (SAVI). Remote Sensing of Environment, v.25, p.295-309, 1988.

HUTCHINSON, M.F. Interpolating mean rainfall using thin plate smoothing splines. International Journal of Geographical Information Systems, v.9, n.4, p.385-403, 1995.

HUTSON, J.L. Applying one-dimensional deterministic chemical fate models on a regional scale. Geoderma, v.60, p.201-212, 1993. 
HUTSON, J.L.; WAGENET, R.J. A pragmatic field-scale approach for modeling pesticides. Journal of Environmental Quality, v.22, p.494499, 1993.

INSTITUTO NACIONAL DE PESQUISA ESPACIAIS. SPRING versão 2.0.4: software de GIS e sensoriamento. São José dos Campos, 1997.

INSKEEP, W.P.; WRAITH, J.M.; WILSON, J.P.; SNYDER, R.D.; MACUR, R.E. Input parameter and model resolution effects on solute transport predictions. Journal of Environmental Quality, v.25, n.3, 1996.

IORGULESCU, I.; JORDAN, J.P. Validation of TOPMODEL on a small Swiss catchment. Journal of Hydrology, v.159, p.255-273, 1994.

JACKSON, R. D. Spectral indices in n-space. Remote Sensing of Environment, v.13: p.409-421, 1983.

JAMES, D.E., AND HEWITT, M.J. To save a river: building a resource decision support system for the Blackfoot River drainage. GeoInfo Systems, v.2, n.10, p.36-49, 1992.

JOAO, E.M.; WALSH, S.J. SIG implications for hydrologic modeling: simulation of nonpoint pollution generated as a consequence of watershed development scenarios. Computers, Environment, and Urban Systems v.16, n.1, p.43-63, 1992. 
JORDAN, C. F. Derivation of leaf area index from quality of light on the forest floor. Ecology, v.50, p.663-666, 1969.

KAUFMAN, Y. J.; TANRÉ D. Atmospherically resistant vegetation index (ARVI) for EOS-MODIS. In: IEEE INTERNATIONAL GEOSCIENCE AND REMOTE SENSING SYMPOSIUM '92, New York, 1992. Proceedings. New York: IEEE, 1992. p.261-270.

KAUTH, R. J.; THOMAS G. S. The tasseled cap: a graphic description of the spectral; temporal development of agricultural crops as seen by landsat In: SYMPOSIUM ON MACHINE PROCESSING OF REMOTELY SENSED DATA, West Lafayette, 1976. Proceedings. West Lafayette: Purdue University, 1976. p.41-51.

KINNELL, P.I.A.; MCGREGOR, K.C.; ROSEWELL, C.J. The IxEa index as an alternative to the EI30 erosivity index. Transactions of the American Society of Agricultural Engineers, v.37, n.5, p.1449-1156, 1995.

LANE, L.J. Development of a procedure to estimate runoff and sediment transport in ephemeral streams. In: WALLING, D.E. (Ed.) Recent developments in the explanation and prediction of erosion and sediment yield. Wallingford: International Association of Hydrological Sciences, 1982. p.275-282. (Publication, 137). 
LEPRIEUR, C.; VERSTRAETE M. M.; PINTY B.; CHEHBOUNI A. NOAA/AVHRR vegetation indices: suitability for monitoring fractional vegetation cover of the terrestrial biosphere. In: INTERNATIONAL SYMPOSIUM ON PYSICAL AND REMOTE SENSING, 1994. Proceedings, 1994. p.1103-1110.

LILLESAND, T. M.; KIEFER R. W. Remote sensing and image interpretation. 2.ed. New York: John Wiley, 1987. 721 p.

NELSON, R. Dryland management: the desertification problem. The World Bank Planning and Research Staff, Environmental Department, 1988. v.8, 42p.

MAAS, E.V.; HOFFMAN, G.J. Crop salt tolerance: current assessment. Journal Irrigation and Drainage Division. ASCE, v.103, n.IR2, p.115134, 1977.

MAINGUET; M. Desertification: natural background and human mismanagement. 2.ed. Berlin: Springer-Verlag, 1994.314p.

MOORE, I.D. Hydrologic modeling and GIS. In: GOODCHILD, M.F.; STEYAERT, L.T.; PARKS, B.O.; CRANE, M.P.; JOHNSTON, C.A.; MAIDMENT, D.R.; GLENDINNING, S. (Ed.) GIS and environmental modeling: progress and research issues. Fort Collins: GIS World, Inc., 1996. p.143-148. 
MOORE, I.D.; GALLANT, J.C. Overview of hydrologic and water quality modeling. In: MOORE, I.D. (Ed.) Modeling the fate of chemicals in the environment. Canberra: Australian National University, Centre for Resource and Environmental Studies, 1991. p. 1-8.

MOORE, I.D.; WILSON, J.P. Length-slope factors for the revised universal soil loss equation: simplified method of estimation. Journal of Soil and Water Conservation, v.47, n.5, p.423-428, 1992.

MOORE, I.D.; AND WILSON, J.P. Reply to "comment on length-slope factors for the revised: universal loss equation - simplified method of estimation" by George R. Foster. Journal of Soil and Water Conservation, v.49, n.2, p.174-180, 1994.

MOORE, I.D.; TURNER, A.K.; WILSON, J.P.; JENSON, S.K.; BAND, L.E. GIS and land surface-subsurface modeling. In: GOODCHILD, M.F.; PARKS, B.O.; STEYAERT, L.T. (Eds) Environmental modeling with GIS. New York: Oxford University Press, 1993. p.196-230.

MORRIS, D.M., AND HEERDEGEN, R.G. Automatically derived catchment boundaries and channel networks and their hydrological applications. Geomorphology, v.1, n.2, p.131-141, 1988.

MURRAY, B.C.; HAMMOND, A.; RODENBURG, E. Global environmental monitoring: pathways to responsible planetary management. Washington: World Resources Institute, 1994.30p. 
NICHOLLS, P.H.; WALKER, A.; BAKER, R.J. Measurement and simulation of the movement and degradation of atrazine and metribuzin in a fallow soil. Pesticide Science, v.13, p.484-494, 1982.

NOFZIGER, D.L.; HORNSBY, A.G. A microcomputer-based management tool for chemical movement in soil. Applied Agricultural Research, v.1, n.1, p.50-56, 1986.

NOFZIGER, D.L., AND HORNSBY, A.G. Chemical movement through layered soils model users manual. Gainesville: University of Florida, Florida Cooperative Extension Service, Institute of Food and Agricultural Sciences, 1987. 56p.

OBLED, CH.; WENDLING, J.; BEVEN, K.J. (1994) The sensitivity of hydrological models to spatial rainfall patterns: an evaluation using observed data. Journal of Hydrology, v.159, p.305-333, 1994.

O'CALLAGHAN, J.F.; MARK, D.M. The extraction of drainage networks from digital elevation data. Computer Vision, Graphics and Image Processing, v.28, p.323-344, 1984.

PANUSKA, J.C.; MOORE, I.D.; KRAMER, L.A. Terrain analysis: integration into the agricultural nonpoint source (AGNPS) pollution model. Journal of Soil and Water Conservation, v.46, n.1, p.59- 64, 1991. 
PENNELL, K.D.; HORNSBY, A.G.; JESSOP, R.E.; RAO, P.S.C. Evaluation of five simulation models for predicting aldicarb and bromide behavior under field conditions. Water Resources Research, v.26, p.2679-2693, 1990.

PETACH, M.C.; WAGENET, R.J.; DEGLORIA, S.D. Regional water flow and pesticide leaching using simulations with spatially distributed data. Geoderma, v.48, p.245-269, 1991.

PICKUP, G.; CHEWINGS V. H.; NELSON D. J. Estimating changes in vegetation cover over time in arid rangelands using Landsat MSS data. Remote Sensing of Environment, v.43, p.243-263, 1993.

PINTY, B.; VERSTRAETE M. M. GEMI: a non-linear index to monitor global, vegetation from satellites. Vegetatio, v.101, p.15-20, 1991.

PRENDERGAST, J. B. A model of crop yield response to irrigation water salinity: theory, testing and application. Irrigation Science, v.13, p.157164, 1993.

QI, J.; CHEHBOUNI A.; HUETE A. R.; KERR Y. H. Modified soil adjusted vegetation index (MSAVI). Remote Sensing of Environment, v.48, p.119-126, 1994.

QUINN, P.F.; BEVEN, K.J. Spatial and temporal predictions of soil moisture dynamics, runoff, variable source areas and evapotranspiration for Plynlimon, Mid-Wales. Hydrological Processes, v.7, p.425-448, 1993. 
QUINN, P.F.; BEVEN, K.J.; CHEVALLIER, P.; PLANCHON, O. The prediction of hillslope paths for distributed hydrological modelling using digital terrain models. Hydrological Processes, v.5, n.1, p.59-79, 1991.

QUINN, P.F.; BEVEN, K.J.; LAMB, R. The $\ln (\mathrm{a} / \tan \beta)$ index: how to calculate it and how to use it within the TOPMODEL framework. Hydrological Processes, v.9, p.161-182, 1995.

RAHMAN, S.; VANCE, G.F.; MUNN, L.C. Detecting salinity and soil nutrient deficiences using spot satellite data. Soil Science, v.158, p.3139, 1994.

RAWLS, W.J.; BRAKENSIEK, D.L. Estimating soil water retention from soil properties. Journal of the Irrigation Division, American Society for Civil Engineers, v.108, p.166-171, 1982.

RENARD, K.G.; FOSTER, G.R.; WEESIES, G.A.; MCCOOL, D.K.; YODER, D.C. Predicting soil erosion by water: a guide to conservation planning with the revised universal soil loss equation. Washington, D.C.: U.S. Department of Agriculture, 1993. 223p. (Agriculture Handbook, 703)

RHOADES, J. D. Drainage for salinity control. In: SCHILFGARDE J. van (Ed.) Drainage for agriculture. Madison: American Society of Agronomy, 1974. cap.15, p.433-461.(ASA. Agronomy, 17). 
RHOADES, J. D.; KANDIAH, A.; MASHAL, A. M. The use of saline water for crop production. Rome: FAO, 1992. 133p. (FAO. Irrigation and Drainage Paper, 48).

RICHARDS, L.A. (Ed. ). Diagnosis and improvement of saline and alkali soils. Washington: USDA, Salinity Laboratory, 1954. 160p. (USDA. Agriculture Handbook, 60).

RICHARDSON, A. J.; WIEGAND, C. L. distinguishing vegetation from soil background information. Photogrammetric Engineering and Remote Sensing, v.43, p.1541-1552, 1977.

RICHARDSON, C.W.; WRIGHT, D.A. WGEN: a model for generating daily weather variables. Washington: United States Department of Agriculture, 1984. 180p. (Report, ARS-8).

RICHARDSON, A. J.; EVERITT, J. H. Using spectral vegetation indices to estimate rangeland productivity. Geocarto International, v.1, p.63-69, 1992.

RITCHIE, J.C., AND MCHENRY, J.R. Application of radioactive fallout Cesium-137 for measuring soil erosion and sediment accumulation rates and patterns: a review. Journal of Environmental Quality, v.19, p.215233, 1990. 
ROBSON; A.J.; BEVEN, K.J.; NEAL, C. Towards identifying sources of subsurface flow: a comparison of components identified by a physically based runoff model and those determined by mixing techniques. Hydrological Processes ,v.6, p.199-214, 1992.

ROBSON, A.J.; WHITEHEAD, P.G.; JOHNSON, R.C. An application of a physically based semi-distributed model to the Balqubidder catchments. Journal of Hydrology, v.145, p.357-370, 1993.

RODENBERG, E. Eyeless in gaia: the state of global environmental monitoring. Washington: World Resources Institute, 1991. 101 p.

ROMANOWICZ, R.; BEVEN, K.J.; MOORE, R. TOPMODEL as an application module within WIS. In: KOVAR, K.; NACHPAECEL, H.P. (Ed.) Applications of Geographic Information Systems in hydrology and water resources. Wallingford: International Association of Hydrological Sciences, 1993. p.211-223 (Publication, 211).

RUNNING,S.W.; THORNTON P.E. Generating daily surfaces of temperature and precipitation over mountainous terrain. In: GOODCHILD, M. F.; STEYART, L.T.; PARKS, B.O.; CRANE, M.P.; JOHNSTON, C.A.; MAIDMENT, D.R.; GLENDINNING, S. (Ed.) GIS and environment modeling: progress and research issues. Fort Collins: GIS World, 1996. p. 93-98. 
SAMMIS, T.; HERRERA, E. Leaching requeriments of pecan and fruit trees. College of Agriculture \& Home Economics, Guide H-644, http://rastro.nmsu.edu/cache/redtops/_h/h-644.html, junho 1996.

SHERIDAN, D. Desertification of the united states. Washington: U.S. Government Printing Office, 1981. 142 p.

SIVAPALAN, M.; BEVEN, K.J.; WOOD, E.F. On hydrologic similarity: 2, a scaled model of storm runoff production. Water Resources Research, v.23, p.2266-2278, 1987.

STEPHENS, P.R.; MACMILLAN, J.H.; DAIGLE, J.L.; CHILAR, J. Estimating universal soil loss equation factor values with aerial photography. Journal of Soil and Water Conservation, v.40, n.1, p.293-296, 1985.

STEWART, J.I.; DANIELSON, R.E.; HANKS, R.J.; JACKSON, R.M.; HAGAN, W.O.; PRUIT,W.O.; FRANKLIN, W.T.; RILEY, J.P. Optimising crop production through control of water and salinity levels in the soil. Utah: Utah Water Lab, 1977. 150p. (Publication, PRWG 151-1).

SMITH, T.; PEUQUET, D.; MENON, S.; AGARWAL, P. KBGIS-II, a knowledge-based methods. International Journal of Geographical Information Systems, Volume 1, $\mathrm{N}^{\circ}$ 6, 1993. 
SPANGRUD, D.J.; WILSON, J.P.; NIELSEN, G.A.; JACOBSEN, J.S.; TYLER, D.A. Sensitivity of computed terrain attributes to the number and pattern of GPS-derived elevation data. In: ROBERT, P.C., RUST, R.H.; LARSON, W.E. (Ed.) Site-specific management for agricultural systems. Madison: American Society of Agronomy, 1995. p.285- 301.

TAUBER, D.A. The complet linux kit. San Famcisco, US: SYBEX Inc., 1995. 419 p.+ CD-ROM.

TOMLIN, C.D. The map analysis package. New Haven: School of Forestry and Environmental Science, Yale University, 1980. 200p.

TUCCI, C. E. M. (Org.) Hidrologia: ciência e aplicação. Porto Alegre: Ed. da Universidade, 1993. 943p.

UNITED NATIONS. Environment Programme United Nations Conference on Desertification: roundup, plan of action and resolutions. United Nations,New York, 1978.107p.

UNITED NATIONS. Environment Programme. Financing anydesertification programmes, Nairobi: UNEP, 1991. 82p.

UNITED NATIONS. Environment Programme Status of desertification and implementation of the United Nations Plan of Action to Combat Desertification. Nairobi: UNEP, 1992. 88p.

UNITED STATES. Department of Agriculture Soil survey manual, Washington, 1993. 437 p. (USDA. Handbook,18). 
VENKATARATNAM, L. Remote sensing for studies on land degradation. Indian Farming, p.51-56, Dec. 1994.

VENTURA, S.J.; CHRISMAN, N.R.; CONNORS, K.; GURDA, R.F.; MARTIN, R.W. A land information system for soil erosion control planning. Journal of Soil and Water Conservation v.43, n.3, p.230$233,1988$.

VILLELA, S.M.; MATTOS, A. Hidrologia aplicada. São Paulo: McGrawHill do Brasil, 1975. 245p.

WAGENET, R.J., AND HUTSON, J.L. LEACHM - leaching estimation and chemistry model: a process based model of water and solute movement, transformations, plant uptake, and chemical reactions in the unsaturated zone. Ithaca: Water Resources Institute, Cornell University, 1989. 230p.

WAGENET, R.J.; HUTSON, J.L. Scale dependency of solute transport modeling/GIS applications. Journal of Environmental Quality, v.25, n.3, p. 250-266, 1996.

WAGENET, R.J.; HUTSON, J.L.; BIGGAR, J.W. Simulating the fate of a volatile pesticide in unsaturated soil: a case study. Journal of Environmental Quality, v.18, p.78-83, 1989. 
WARREN, A.; AGNEW, C. An assessment of desertification and land degradation in arid and semi-arid areas. London: University College, International Institute for Environmental Development, Drylands Programme, 1988. $72 \mathrm{p}$.

WIEGAND, C.L.; RHOADES, J.D.; EVERITT, J.H.; ESCOBAR, D. E. Comparision of photography, videography and spot-1 hrv digital observation for salinity assessment in the san joaquin valley of califomia. Land Reclamation: Advances in Research \& Tecnology, Proceedings of the International Symposium, p.14-15, Dec.1992, Nashville, Tennessee.

WILSON, J.P. Soil erosion from agricultural land in the Lake SimcoeCouchiching Basin, 1800-1981. Canadian Journal of Soil Science, v.69, n.2, p.206-222, 1989.

WILSON, J.P.; GALLANT, J.C. EROS: a grid-based program for estimating spatially-distributed erosion indices. Computers and Geosciences, v.22, n.4, 1996.

WILSON, J.P.; INSKEEP, W.P.; RUBRIGHT, P.R.; COOKSEY, D.; JACOBSEN, J.S.; SNYDER, R.D. Coupling geographic information systems and models for weed control and groundwater protection. Weed Technology, v.7, n.1, p.255-264, 1993. 
WISCHMEIER, W.H.; SMITH, D.D. Predicting rainfall erosion losses: a guide to conservation planning. Washington: U.S. Department of Agriculture, 1978. 155p. (USDA. Agriculture Handbook, 537).

WOLOCK, D.M. Effects of subbasin size on topographic characteristics and simulated flow paths in Sleepers River watershed, Vermont. Water Resources Research, v.31, n.8, p.1989-1997, 1995.

WOLOCK, D.M.; MCCABE, G.J. Comparison of single and multiple flow direction algorithms for computing topographic parameters in TOPMODEL. Water Resources Research, v.31, n.5, p.1315- 1324, 1994.

WOLOCK, D.M.; HORNBERGER, G.M.; MUSGROVE, T.M. Topographic effects on flow path length and surface water chemistry of the Llyn Brianne catchments. in Wales. Journal of Hydrology, v.115, p.243-259, 1990.

WORLD RESOURCES INSTITUTE. World resources 1992-1993, Oxford: Oxford University Press, 1992. 385p.

WORLD RESOURCES INSTITUTE. World resources 1993-1994, Oxford: Oxford University Press, 1993. 385p.

YOUNG, R.A.; OTTERBY, M.A.; ROOS, A. A technique for evaluating feedlot pollution potential. Journal of the Soil and Water Conservation, v.37, n.1, p.21-23, 1982. 
YOUNG, R.A.; ONSTAD, C.A.; BOSCH, D.D.; ANDERSON, W.P. AGNPS, Agricultural Nonpoint Source Pollution Model: a large watershed analysis tool. Washington: U.S. Department of Agriculture, Agricultural Research Service Conservation, 1987. 135p. (Research Report, 35).

YOUNG, R.A.; ONSTAD, C.A.; BOSCH, D.D.; ANDERSON, W.P. AGNPS: a nonpoint source pollution model for evaluating agricultural watersheds. Journal of the Soil and Water Conservation, v.44, n.2, p.168-173, 1989.

ZHANG, W.; MONTGOMERY D.R. Digital elevation model grid size, landscape representation, and hydrologic simulations. Water Resources Research, v.30, n.4, p.1019-1028, 1994. 
ANEXO 
1: Programa em LEGAL de cruzamento função Prendergats para LF de $10 \%$

,

Tematico Cw ("Zoneam da_Salinidade"), pe ("Manejo"). ETP ("Climatologia"). P("Climatologia"): Tematico LF010 ("Producao"): $\mathrm{Cw}=$ Recupere(Nome="sal_hidric"): $\mathrm{pe}=$ Recupere $($ Nome="asilpas87"): ETP = Recupere $($ Nome $=" E p "): P=$ Recupere ( Nome="R"): LF0 $10=$ Novo (Nome="Prod_rel_LF10\%". ResY $=250, \operatorname{Res} Y=250$. Escala $=500000$ ): LF010 = Atribua(Categoria Fim="Producao")

"100_80": (Cw.Classe=="<1000" \&\& pe.Classe=="Agricola" \&\& ETP.Classe=="1300_1400" \&\& P.Classe=="400_500"). "100_80": (Cw.Classe=="<1000" \&\& pe.Classe==".Agricola" \&\& ETP.Classe=="1300_1400" \&\& P.Classe=="600 700"). "100_80": (Cw.Classe $=="<1000 "$ \&\& pe.Classe $=="$ Agricola" \&\& ETP.Classe=="1300_1400" \&\& P.Classe $\left.==" 800 \_900 "\right)$.

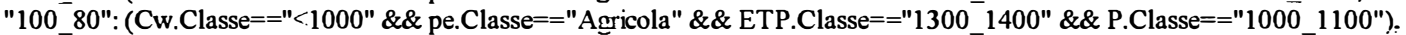
"100_80": (Cw.Classe $=="<1000 "$ \&\& pe.Classe $=="$ Agricola" \&\& ETP.Classe $==" 1500 \_1600 "$ \&\& P.Classe $\left.==" 400 \_500 "\right)$. "100 80": (Cw.Classe $=="<1000 "$ \&\& pe.Classe=="Agricola" \&\& ETP.Classe=="1500 1600" \&\& P.Classe=="600_700"). "100_80": (Cw.Classe $=="<1000 "$ \&\& pe.Classe $=="$ Agricola" \&\& ETP.Classe $==" 1500 \_1600 "$ \&\& P.Classe $\left.==" 800 \_900 "\right)$, "100_80": (Cw.Classe==" $<1000 "$ " \& pe.Classe=="Agricola" \& \& ETP.Classe=="1500_1600" \& \& P.Classe $==" 100011100 ")$. "100_80": (Cw.Classe $=="<1000 " \& \&$ pe.Classe $=="$ Agricola" \&\& ETP.Classe $==" 1700 \_1800 "$ \&\& P.Classe $==" 400 \_500 "$ ). "100_80": (Cw.Classe="<1000" \&\& pe.Classe="Agricola" \&\& ETP.Classe=="1700_1800" \&\& P.Classe=="600_700").

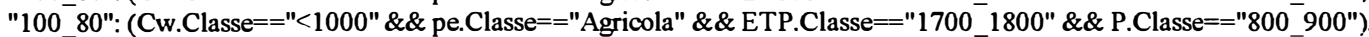
"100_80": (Cw.Classe $=="<1000 "$ \& \& pe.Classe $=="$ Agricola" \& \& ETP.Classe $==" 1700 \_1800 "$ \& \& P.Classe $\left.==" 1000 \_1100 "\right)$. "100 80": (Cw.Classe $=="<1000 "$ \&\& pe.Classe $=="$ Agricola" \& \& ETP.Classe $==" 1900 \_2000 "$ \& \& P.Classe $\left.==" 400 \_500 "\right)$. "100_80": (Cw.Classe=="<1000" \&\& pe.Classe ="Agricola" \&\& ETP.Classe=="1900_2000" \&\& P.Classe=="600_700").

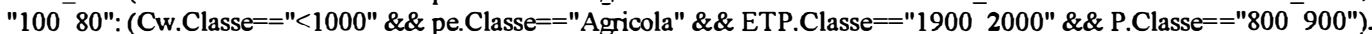
"100_80": (Cw.Classe==" $<1000 "$ \&\& pe.Classe=="Agricola" \& \& ETP.Classe=="1900_2000" \&\& P.Classe=="1000_1100"). "100_80": (Cw.Classe $=="<1000 "$ \&\& pe.Classe $=="$ Agricola" \&\& ETP.Classe $==" 2100 \_2200 "$ \& \& P.Classe $\left.==" 400 \_500 "\right)$. "100_80": (Cw.Classe $=="<1000 "$ \&\& pe.Classe $=="$ Agricola" \& \& ETP.Classe $==" 2100 \_2200 "$ \& \& P.Classe $\left.==" 600 \_700 "\right)$ "100 80": (Cw.Classe $=="<1000 "$ \& \& pe.Classe $=="$ Agricola" \&\& ETP.Classe $==" 2100-2200 "$ " \& P.Classe $==" 800$ 900"). "100_80": (Cw.Classe==" $<1000 "$ \&\& pe.Classe=="Agricola" \&\& ETP.Classe=="2100_2200" \&\& P.Classe $==" 1000 \_1100 "$ ). "100_80": (Cw.Classe $==" 1000-2500 "$ \&\& pe.Classe $=="$ Agricola" \&\& ETP.Classe $==" 1300 \_1400 "$ \&\& P.Classe $\left.==" 400 \_500 "\right)$, "100_80": (Cw.Classe=="1000-2500" \&\& pe.Classe=="Agricola" \& \& ETP.Classe=="1300_1400" \&\& P.Classe=="600_700"), "100_80": (Cw.Classe=="1000-2500" \&\& pe.Classe $=="$ Agricola" \& \& ETP.Classe $==" 1300 \_1400$ " \& \& P.Classe $\left.==" 800 \_900 "\right)$, "100_80": (Cw.Classe=="1000-2500" \&\& pe.Classe=="Agricola" \&\& ETP.Classe=="1300_1400" \&\& P.Classe=="1000_1100"), "100 80": (Cw.Classe $==" 1000-2500 "$ \& \& pe.Classe $=="$ Agricola" \& \& ETP.Classe $==" 1500$ 1600" \& \& P.Classe $==" 400$ 500"), "100_80": (Cw.Classe $==" 1000-2500 "$ \& \& pe.Classe=="Agricola" \& \& ETP.Classe=="1500_1600" \&\& P.Classe $\left.==" 600 \_700 "\right)$, "100 80": (Cw.Classe $==" 1000-2500 " \& \&$ pe.Classe $=="$ Agricola" \& \& ETP.Classe $==" 1500 \_1600 "$ \& \& P.Classe $\left.==" 800-900 "\right)$, "100_80": (Cw.Classe $==" 1000-2500 " \& \&$ pe.Classe=="Agricola" \& \& ETP.Classe $==" 1500 \_1600 "$ \& \& .Classe $==" 1000+1100 "$ ), "100_80": (Cw.Classe $==" 1000-2500 "$ \& \& pe.Classe $=="$ Agricola" \& \& ETP.Classe $==" 1700 \_1800 "$ \& \& P.Classe $\left.==" 400-500 "\right)$, "100_80": (Cw.Classe $==" 1000-2500 "$ \&\& pe.Classe=="Agricola" \& \& ETP.Classe=="1700_1800" \&\& P.Classe $\left.==" 600 \_700 "\right)$, "100 80": (Cw.Classe $==" 1000-2500 "$ \& \& pe.Classe $=="$ Agricola" \& \& ETP.Classe $==" 1700 \_1800 "$ \& \& P.Classe $\left.==" 800-900 "\right)$, "100_80": (Cw.Classe $==" 1000-2500 "$ \& \& pe.Classe=="Agricola" \& \& ETP.Classe=="1700_1800" \&\& P.Classe $\left.==" 1000 \_1100 "\right)$, "100 80": (Cw.Classe $==" 1000-2500 "$ \& \& pe.Classe $=="$ Agricola" \& \& ETP.Classe $==" 1900$ 2000" \&\& P.Classe $==" 400 \quad \overline{500}$ "), "100_80": (Cw.Classe=="1000-2500" \&\& pe.Classe=="Agricola" \&\& ETP.Classe=="1900_2000" \&\& P.Classe=="600_700"), "100 80": (Cw.Classe $==" 1000-2500 "$ \& \& pe.Classe $=="$ Agricola" \& \& ETP.Classe $==" 1900$ 2000" \& \& P.Classe $==" 800900 "$ ). "100_80": (Cw.Classe $==" 1000-2500 "$ \&\& pe.Classe=="Agricola" \& \& ETP.Classe=="1900_2000" \&\& P.Classe $\left.==" 1000 \_1100 "\right)$ "100 80": (Cw.Classe $==" 1000-2500 "$ \&\& pe.Classe $=="$ Agricola" \& \& ETP.Classe $==" 2100-2200 "$ \& \& P.Classe $==" 400$ 500"), "100_80": (Cw.Classe $==" 1000-2500 "$ \& \& pe.Classe $=="$ Agricola" \& \& ETP.Classe $==" 2100 \_2200 "$ \& \& P.Classe $\left.==" 600 \_700 "\right)$, "100 80": (Cw.Classe $==" 1000-2500 "$ \& \& pe.Classe $=="$ Agricola" \& \& ETP.Classe $==" 2100$ 2200" \& \& P.Classe $==" 800-900 ")$, "100_80": (Cw.Classe=="1000-2500" \&\& pe.Classe=="Agricola" \& \& ETP.Classe=="2100_2200" \&\& P.Classe $\left.==" 1000 \_1100 "\right)$ "80 60": (Cw.Classe ==">2500" \&\& pe.Classe=="Agricola" \&\& ETP.Classe $==" 1300 \quad 1400 "$ \&\& P.Classe $==" 400 \quad 500 "$ "), "100_80": (Cw.Classe==">2500" \&\& pe.Classe $=="$ Agricola" \& \& ETP.Classe $==" 1300 \_1400 "$ \& \& P.Classe $\left.==" 600 \_700 "\right)$, "100_80": (Cw.Classe $==">2500 "$ \&\& pe.Classe $=="$ Agricola" \& \& ETP.Classe $==" 1300 \_1400 "$ \& \& P.Classe $\left.==" 800 \_900 "\right)$. "100_80": (Cw.Classe $==">2500 "$ \& \& pe.Classe=="Agricola" \&\& ETP.Classe=="1300_1400" \&\& P.Classe=="1000_1100"), "80 60": (Cw.Classe==">2500" \&\& pe.Classe=="Agricola" \&\& ETP.Classe=="1500_1600" \&\& P.Classe=="400_500"), "100_80": (Cw.Classe==">2500" \&\& pe.Classe-"Agricola" \&\& ETP.Classe=="1500_1600" \&\& P.Classe $\left.==" 600 \_700 "\right)$. "100_80": (Cw.Classe $==">2500 "$ \&\& pe.Classe $=="$ Agricola" \&\& ETP.Classe $==" 1500 \_1600 "$ \&\& P.Classe $==" 800 \_900 "$ "). "100_80": (Cw.Classe $==">2500 "$ \& \& pe.Classe $=="$ Agricola" \&\& ETP.Classe $==" 1500 \_1600 "$ \&\& P.Classe $\left.==" 1000 \_1100 "\right)$. "80_6": (Cw.Classe $==">2500 "$ \& \& pe.Classe=="Agricola" \&\& ETP.Classe=="1700_1800" \&\& P.Classe=="400_500"), "80 60": (Cw.Classe $==">2500 "$ \&\& pe.Classe=="Agricola" \& \& ETP.Classe=="1700_1800" \&\& P.Classe $==" 600$ "100 80": (Cw.Classe $==">2500 "$ \& \& pe.Classe $=="$ Agricola" \& \& ETP.Classe $==" 1700 \quad 1800 "$ \& \& P.Classe $==" 800900 "$ ), "100_80": (Cw.Classe==">2500" \&\& pe.Classe=="Agricola" \&\& ETP.Classe=="1700_1800" \&\& P.Classe=="1000_1100"). "80 60": (Cw.Classe==">2500" \&\& pe.Classe=="Agricola" \&\& ETP.Classe $==" 1900$ 2000" \&\& P.Classe $==" 400-500 ")$, "80 60": (Cw.Classe==">2500" \&\& pe.Classe="Agricola" \&\& ETP.Classe=="1900 2000" \&\& P.Classe=="600 700"). "100_80": (Cw.Classe $==">2500 "$ \&\& pe.Classe=="Agricola" \&\& ETP.Classe $==" 1900 \_2000 "$ \& \& P.Classe $\left.==" 800 \_900 "\right)$. "100_80": (Cw.Classe==">2500" \&\& pe.Classe $=="$ Agricola" \&\& ETP.Classe=="1900_2000" \&\& P.Classe $\left.==" 1000 \_1100 "\right)$. "80_60": (Cw.Classe=="> 2500" \&\& pe.Classe=="Agricola" \&\& ETP.Classe $==" 2100 \_2200 "$ \&\& P.Classe $\left.==" 400 \_500 "\right)$ "80_60": (Cw.Classe=="> 2500" \&\& pe.Classe $=="$ Agricola" \&\& ETP.Classe $==" 2100 \_2200 "$ \&\& P.Classe $==" 600700 "$ "). "100 80": (Cw.Classe==">2500" \&\& pe.Classe=="Agricola" \& \& ETP.Classe=="2100 2200" \&\& P.Classe $==" 800$ "100_80": (Cw.Classe==">2500" \&\& pe.Classe=="Agricola" \&\& ETP.Classe $==" 2100 \_2200 "$ \&\& P.Classe $\left.==" 1000 \_1100 "\right)$ \}; // O mesmo procedimento em LEGAL foi realizado para as fraçōes de lixiviação de $5 \%$ e $1 \%$, pela //substituição do LF igual a 5 e o LF igual a 1, respectivamente, na equação 16 . resolven do-a para todas //as variáveis do modelo. Obviamente os Atributos da CategoriaFim serão modificados. resultando nas //Figuras 23 e 22. respectivamente. 